\title{
3 Trends in the Regulation of Stock Exchanges
}

\subsection{General Remarks}

Equity markets are regulated on a piece-meal basis. Stock exchange laws focus on the marketplace. Stock exchange laws are complemented by the regulation of market participants and their actions in company law and securities law. There are even other relevant areas of sectoral regulation such as the regulation of financial intermediaries and tax laws.

Stock exchanges have been seen as a public good. ${ }^{1}$ In mainstream economics and legal science, it has been assumed that "[s]tock exchanges play a decisive role in capital allocation and provide key infrastructure for a country's markets". ${ }^{2}$ In particular, it is believed that "[e]xchanges are the main gateway through which corporate issuers access public financing [and that exchanges] provide liquid secondary markets, which are a precondition for effective primary markets." ${ }^{3}$ For these reasons, "each country has established a strict regulatory framework to safeguard the operation of its stock market". ${ }^{4}$ The state may need to protect the function, integrity, efficiency, and stability of stock exchanges and public stock markets. ${ }^{5}$

But something seems to have gone wrong in the light of the fact that the number of companies with publicly-traded shares is low and IPOs are not as popular as they used to be. ${ }^{6}$

1 Fleckner AM (2006) p 2592: “As Congress wrote into the Securities Exchange Act in 1975, 'The securities markets are an important national asset which must be preserved and strengthened."” 2 Gadinis S, Jackson HE (2007) pp 1242-1243. For the mechanisms, see Fox MB, Glosten LR, Rauterberg GV (2019) pp 35-36.

3 Gadinis S, Jackson HE (2007) p 1249.

4 Ibid., pp 1242-1243.

5 Mues J (1999) p 48: “Als anerkanntes Regelungsziel deutscher Börsengesetzgebung hat sich Funktionsschutz bzw. Funktionsfähigkeit der Börse erst in den sechziger Jahren im Gefolge der auf europäischer Ebene geführten Kapitalmarktdiskussion durchgesetzt ... Unter dem Begriff 'Funktionsschutz" ist nach alledem ein Bündel von Regelungszwecken zu fassen, denen allein gemein sind, daß sie auf eine Steigerung der Effizienz des Kapitalmarktes gerichtet sind.” Ibid., p 48: "Die gesetzliche Berücksichtigung von Anlegerschutzinteressen wird aus dem verfassungsrechtlichen Sozialstaatsprincip hergeleitet.” For a list of functions for stock exchanges from a policy perspective, see Gadinis S, Jackson HE (2007) pp 1248-1250. See also Moloney N (2014) V.1.2.2, p 429: "The regulation of trading venues is primarily directed to ensuring market integrity, efficiency, and stability; in support of these aims, it has long been associated with protecting liquidity."

6 Gao X, Ritter JR, Zhu Z (2013); Diez FJ, Leigh D, Tambunlertchai S (2018).

Ә OpenAccess. (C 2022 Petri Mäntysaari, published by De Gruyter. (cc))BY-NC-ND This work is licensed under the Creative Commons Attribution-NonCommercial-NoDerivatives 4.0 International License.

https://doi.org/10.1515/9783110761108-004 
This raises fundamental questions. Why do stock exchanges do what they do? What explains the existence of stock exchanges and the organisation of their activities? What is the function of stock exchanges? What has gone wrong?

The answers can depend on the function of stock exchanges for different stakeholders. Different market participants use stock exchanges for different purposes. Moreover, the functions of stock exchanges have changed in the course of time. The interests of issuer-firms do not seem to have mattered very much, ${ }^{7}$ which is likely to have made firms opt out of public stock markets.

Non-financial issuers. From the perspective of non-financial issuers, modern stock exchanges provide particular kinds of services (section 8.2). They provide core services and ancillary services.

First, the traditional core service of stock exchanges is to facilitate trading and the provision of liquidity. It has been said that "the business of an exchange involves almost purely the provision of liquidity". 8

Second, stock exchanges facilitate the provision of shareholders' services to the issuer-firm. Trading and liquidity are connected to this core service. Shareholders sometimes act as a source of capital but always as providers of ancillary services to the firm (section 2.3.3). ${ }^{9}$ Stock exchanges can facilitate the provision of both kinds of shareholders' services.

Shareholders either are or are not a source of capital. As a source of capital, they can provide either cash or non-cash assets. ${ }^{10}$ In listed companies, shareholders are not a good source of cash. ${ }^{11}$ In mature companies, internal funding and debt are by far the biggest sources of cash. ${ }^{12}$ Rights issues are rare, because

7 For example, the interests of the issuer-firm were not recognised in Fox MB, Glosten LR, Rauterberg GV (2019) pp 36-37. The authors represent the view that maximising share price is in society's best interests.

8 Macey JR, O’Hara M (2005) pp 568-569. See even Mahoney PG, Rauterberg GV (2018) p 225. 9 Mäntysaari P (2010a) section 8.7 and sections 9.2.5-9.2.6; Mäntysaari P (2012) section 7.9. 10 For example, Articles 70 and 72 of Directive (EU) 2017/1132 (Directive relating to certain aspects of company law) distinguish between increase in capital by consideration in cash and by consideration other than in cash.

11 Doidge C, Kahle KM, Karolyi GA (2018) p 9 on how US have been repurchasing more equity than they have issued: “The amount spent on repurchases since 1997 is \$3.6 trillion greater than the amount raised from issuing equity over the same period.” This figure does not include dividends paid to shareholders during the same period of time. See ibid., $\mathrm{p} 13$.

12 Mayer C (1990) p 310; Mayer C (1998); Holmström B (2015) p 7; Mishkin FS, Eakins SG (2012) p 64: "Although the dominance of financial intermediaries over securities markets is clear in all countries, the relative importance of bond versus stock markets differs widely across countries. In the United States, the bond market is far more important as a source of corporate finance: On average, the amount of new financing raised using bonds is 10 times the amount raised using 
they can reduce share price. Shareholders may nevertheless be a valuable source of non-cash assets. For example, it is customary for a listed company to use its shares as a means of payment in mergers or share exchanges. The target's shareholders will then become the acquirer's shareholders.

In all companies, shareholders always provide ancillary services. Such ancillary services have been called "non-cash contributions" or "non-capital contributions" in the venture capital context ${ }^{13}$ with "non-capital contributions" perhaps the better term to describe ancillary services.

Many of the ancillary services of shareholders relate to what Hirschman calls exit, voice, and loyalty. ${ }^{14}$ Combined with the transferability of shares (exit), the mechanism of price discovery facilitates the valuation of shares by shareholders and gives them an incentive to monitor management (voice). The market valuation mechanism and the firm's voluntary submission to the legal framework of the exchange act as constraints on the governance and management of the firm, reduce the perceived risk exposure of long-term investors, and facilitate long-term investments (loyalty).

From the perspective of the firm, some shareholders are better sources of capital and/or ancillary services than other shareholders. ${ }^{15}$ For example, when listed companies need cash and equity capital, rights issues may be replaced by private investments in public equity (PIPEs). ${ }^{16}$ Founders, controlling shareholders, and large blockholders can be particularly valuable providers of ancillary services, but modern stock exchanges facilitate the provision of some ancillary services even by retail investors. ${ }^{17}$

stocks. By contrast, countries such as France and Italy make more use of equities markets than of the bond market to raise capital."

13 Gilson RJ (2003).

14 Hirschman AO (1970).

15 Mäntysaari P (2010a) section 8.7.2; Mäntysaari P (2012) section 7.9. For the services provided by venture capital investors, see, for example, Gilson RJ, Black BS (1998); OECD (2015c) paragraphs 349-351. See also Ibrahim DM (2015) pp 591-592 on how most startups probably still need both an investor's cash and value-added services.

16 Richard Henderson, Cash-strapped US companies ramp up sales of discounted shares. Listed businesses raise $\$ 17 \mathrm{bn}$ so far this year from cut-price sales to private equity groups. Financial Times, 14 April 2020.

17 See, for example, Hill J (2021) section 2.1 p 20 on founders; Macey JR, Miller PP (1995-1996) p 81 on blockholders: "In Germany and Japan, large block shareholders take an active management role to mitigate managerial shirking and misconduct. By contrast, the American structure of corporate governance largely focuses power in management, particularly in the chief executive officer. For this reason, American shareholders are relatively powerless to affect management decisions ...” 
Third, stock exchanges can provide ancillary services to non-financial issuers. For example, an issuer can use stock exchanges to signal its own quality or the quality of its securities, or, for marketing purposes, to signal the quality of its products. Since a stock exchange listing comes with a regulatory regime, an issuer can use a stock exchange listing for governance purposes. A listing can also be used for the purpose of creating new kinds of incentives for managers.

Finally, the role and nature of stock exchanges has changed over time for issuer-firms. Stock exchanges play a role in the way the governance of listed companies is organised. ${ }^{18}$ Stock exchanges used to play an important role as rulemakers, but this function has to a large extent been replaced by mandatory provisions of law and government regulation. The existence of stock exchanges makes it easier for listed companies to use their shares as a means of payment in mergers and acquisitions, and generally for acquirers to take over companies. However, firms do not issue shares to raise much cash on stock exchanges, the two largest sources of funding for mature companies being retained earnings and debt. ${ }^{19}$ According to The Economist, a newspaper, "[l]istings these days mostly happen to enable early investors and employees with stock options to cash out". ${ }^{20}$

Entrepreneurs, family and friends, financial investors. Investors have different needs and use stock exchanges for different purposes. ${ }^{21}$

In young companies that apply for a stock exchange listing, the listing may provide an exit alternative or a chance to reduce investors' risk exposure. ${ }^{22}$ Shareholders in such companies may include entrepreneurs, family members, the firm's employees, and the firm's financial investors.

Financial investors use stock exchanges as a marketplace for investments ranging from short-term speculation to takeovers. A listed company is in the market for control ${ }^{23}$ and for sale unless it has put in place adequate structural takeover defences. ${ }^{24}$ The number of listed companies has been reduced by mergers and takeovers. Many listed companies have been taken over in private equity deals or intra-industry transactions.

Traders, exchange members, and operators of exchanges. Traders, exchange members, and exchanges operators have their own interests.

18 Holmström B (2015) p 6.

19 Ibid., p 7.

20 The Economist, NOIPO? 16 May 2019.

21 See, for example, Blume ME (2000).

22 Holmström B (2015) p 7.

23 Manne HG (1965).

24 Mäntysaari P (2010c) Chapter 18. 
Traders can benefit from informational advantages and arbitrage opportunities. ${ }^{25}$ High-frequency traders (HFTs) in particular try to benefit from one-sided liquidity that facilitates front running.

If the stock exchange has members, members can act as gatekeepers and sell services to investors that wish to trade on the exchange. Market makers can provide liquidity to the market provided that trading spreads enable them to make a profit.

The operators of stock exchanges have their own distinct interests. While the stock exchanges of the past were mutual associations, the operators of modern stock exchanges are for-profit corporations. Traditional stock exchanges face competition not only inter se but even from alternative trading venues. It can be difficult to draw a line between stock exchanges and other marketplaces for stocks: "The rivalry between exchanges and other marketplaces for stocks, bonds, or commodities is as old as the exchanges themselves, because only the physical and temporal concentration of the trading at the exchanges leads to a separation of the market into exchanges and other venues." ${ }^{26}$ The most influential exchange operators now focus on high volumes, diversification, and the sale of data and technology services. ${ }^{27}$ They have also acquired financial-data service companies. ${ }^{28}$

Choice of interests in the regulation of stock exchanges. What we can see is that a stock exchange is the hub of many conflicting interests. The existence of conflicting interests matters a great deal. The intended role of stock exchanges depends on the choice of societal interests and is therefore a question of values. The prevailing values and societal interests will influence markets and societal outcomes through regulation.

Different societal interests have influenced the nature and regulation of stock exchanges in the past. ${ }^{29}$ After the period of industrialisation that triggered a wave of new stock exchanges, the interests of issuer-firms do not seem to have played any major role in the evolution of stock exchanges or their regulation. The emergence of alternative trading venues, broker-dealer order internalisation, and

25 Holmström B (2015) p 2.

26 Fleckner AM, Hopt KJ (2013) pp 554-556.

27 See, for example, The Economist, Big fish, 29 August 2020.

28 The Economist, Go figure, 5 December 2020. The article describes how S\&P Global acquired IHS Markit for \$44bn, the London Stock Exchange (LSE) bought Refinitiv (the former financialdata service of Thomson Reuters) for $\$ 27 \mathrm{bn}$, and ICE bought Ellie Mae for $\$ 11 \mathrm{bn}$.

29 Compare Weber M (1894): "Wir sehen: die wesentliche Grundlage und die Einrichtungen der Börsen müssen in der Hauptsache gleichartige sein, weil die Bestimmung der Börse überall dieselbe ist.” 
dark pools in recent decades does not seem to have been driven by the interests of issuer-firms.

If the interests of issuer-firms do not matter, exchange regulation is likely to reduce the number of firms that choose public markets regardless of whether existing regulation is perceived as efficient or not in the current scholarly discourse.

The emergence of SME exchanges may be an exception to the long-term trend of the fading relevance of the interests of issuer-firms. However, SME exchanges basically are traditional stock exchanges rather than alternative trading venues. The mechanisms and regulation of traditional stock exchanges are designed for large mature companies with liquid stocks rather than SMEs with illiquid stocks.

Liquidity, concentration and fragmentation. Ensuring liquidity has played an important role in the business and regulation of stock exchanges. In the history of stock exchanges, ensuring liquidity used to require concentration. Concentration tends to be increased by the existence of positive network effects. In recent years, however, the trend has changed from concentration to the fragmentation of trading and marketplaces. The existence of so many stock exchanges and alternative trading venues in the world cannot fully be explained by the existence of national business clusters, national markets, national laws, and strict regulatory frameworks for stock exchanges in different countries. The reasons even seem to include, first, the fact that facilitating trading has become a commodity with various kinds of exchange operators competing for trading volume and, second, the fact that "liquidity" means different things for different market participants. Focusing on "liquidity" in the regulation of stock exchanges in the digital era primarily seems to have meant fostering the interests of high-volume traders or high-frequency traders.

Externalities. The current regulation of stock exchanges has externalities. For example, rules that facilitate the business of high-frequency traders (HFTs) can allocate wealth from all other traders to HFTs. ${ }^{30}$ Rules designed to lower transaction costs for investors in the short term can reduce spreads, hamper market-making, and ultimately reduce the number of small-company IPOs. ${ }^{31}$ In company law, corporate governance rules designed to reduce agency costs for the fictive shareholders of neoclassical economic theory can hamper the business of real firms, reduce the number of listed companies, and limit the investment

30 For the role of exchanges in high-frequency trading, see Kirilenko AA, Kyle AS, Samadi M, Tuzun T (2017); Baron M, Brogaard J, Kirilenko A (2012); Clark-Joseph AD (2013); Lewis M (2015). 31 Weild D, Kim E, Newport L (2013) p 4. 
opportunities of retail investors. Current regulation seems to have contributed to the decline of IPOs.

About this Chapter. What is striking in this Chapter is how little the interests of issuer-firms have mattered. There is a fundamental flaw in the regulation of stock exchanges if the goal is to increase the number of companies with publicly-traded shares.

In this Chapter, we will focus on the evolution of stock exchanges and their regulation. First, for a better understanding of the context, we will have a brief look at the long history of stock exchanges (section 3.2). There is plenty of literature about the history of exchanges. ${ }^{32}$ Second, we will study the emergence of alternative venues (section 3.3). Third, we will study broker-dealer order internalisation and dark pools in EU and US law (section 3.4). Order internalisation and dark pools are growing alternatives to traditional stock exchanges. Fourth, we will study the emergence of SME exchanges (section 3.5).

\subsection{The History of Stock Exchanges}

\subsubsection{General Remarks}

A stock exchange is a particular kind of marketplace. The characteristic aspects of stock exchanges have varied over time. We can have a brief look at the evolution of stock exchanges and try to sum up centuries of innovation.

For much of history, firms have mainly relied on borrowing to raise the bulk of funds from outsiders. Traditionally, it has been easier to establish viable markets for debt securities than for equity securities. ${ }^{33}$ While large-scale impersonal capital markets began by trading in low-risk public debt instruments, ${ }^{34}$ largescale public markets for common stocks grew after the First World War. ${ }^{35}$

Early stock exchanges were marketplaces initiated by traders. Stock exchanges enabled traders to buy and sell shares. With industrialisation, stock exchanges came to be perceived as a channel for firms to raise capital by issuing

32 Christiansen H, Koldertsova A (2009) p 210: "Ever since the first demutualisation of an exchange (Stockholm in 1993) studies of listing, competition, consolidation and internationalisation of exchanges has become a rapidly growing industry."

33 Baskin JB, Miranti PJ Jr (1997) pp 14, 98 and 131.

34 Ibid., p 18.

35 Ibid., pp 14 and 176. 
shares to the public. The importance of liquidity was recognised at the end of the nineteenth century. ${ }^{36}$

But circumstances changed. Stock exchanges needed to grow bigger after the liberalisation of capital movements, ${ }^{37}$ the introduction of greater freedom to provide cross-border services, ${ }^{38}$ increasing financialisation, and digitalisation. Larger scale helped to bring down transaction costs.

After the focus on scale, the nature of stock exchanges changed again. The operators of stock exchanges began to regard stock exchanges as business ventures. Exchange operators turned into conventional firms that were in the business of the operation of marketplaces to make a profit. To increase profits, they diversified into the operation of marketplaces for other financial instruments or commodities and into the provision of various kinds of financial, data and technology services.

\subsubsection{Early History}

Historically, it has been difficult to distinguish between stock exchanges and other marketplaces. The inherent vagueness of the notion of a stock exchange lives to this day. There can be different notions of a stock exchange. This has influenced regulation as well. ${ }^{39}$

Markets and fairs. There were regular markets and fairs in antiquity. ${ }^{40}$ Markets and fairs developed when, with increasing specialisation in society, people needed to exchange their goods and the goods needed to be examined before

36 Lagneau-Ymonet P, Riva A (2019).

37 The Code of Liberalisation of Capital Movements has provided a framework for the liberalisation of capital movements between OECD countries since 1961. The Maastricht Treaty, which entered into force in 1994, introduced the free movement of capital as a Treaty freedom. Article 63 of the TFEU prohibits all restrictions on the movement of capital and payments between Member States, as well as between Member States and third countries.

38 The purpose of the Financial Services Action Plan (FSAP) was to create a single market for financial services within the EU by the end of 2004. The cornerstone of the FSAP was the Markets in Financial Instruments Directive 2004/39/EC (MiFID).

39 See, for example, Köndgen J (1998) pp 224-227; section 3(a)(1) of the Securities Exchange Act of 1934: “The term 'exchange' means any organization, association, or group of persons, whether incorporated or unincorporated, which constitutes, maintains, or provides a market place or facilities for bringing together purchasers and sellers of securities or for otherwise performing with respect to securities the functions commonly performed by a stock exchange as that term is generally understood, and includes the market place and the market facilities maintained by such exchange."

40 See Fleckner AM, Hopt KJ (2013) pp 524-525. 
trading. ${ }^{41}$ The location and duration of markets and fairs were influenced by the available means of transportation, the occurrence of gatherings for religious or other reasons, and safety. There was also competition for business and wealth between different towns or regions. ${ }^{42}$

Modern markets are digital platforms. There are different kinds of digital platforms outside stock markets. A digital platform can be: a distribution channel for the sale of the operator's goods or for the provision of the operator's services; the functional equivalent of a department store with the operator buying and selling goods; an online platform enabling exchanges between sellers and buyers; or an online platform enabling peer-to-peer exchanges in the sharing economy. Online platforms with third-party buyers and sellers are the most important markets in digital economy. ${ }^{43}$ Operators of online platforms generally rely on other people's assets, that is, their intellectual activities (Google), their relationships (Facebook), their goods (Ebay), their private physical assets (Uber), and so forth. The operator of an online platform tries to benefit from positive network effects and monopolise existing or new markets.

The founding of stock exchanges. Regular markets and fairs led to the emergence of venues with standardised trading. The first venues with standardised trading appeared in the Middle Ages, starting the history of commercial exchanges. ${ }^{44}$ The difference between markets and fairs on one hand and commercial exchanges on the other related to settlement: "[A]ccording to the accepted usage on the bourses, articles need not be exhibited to the buyer at the time the contract is made, whereas the customary procedure at fairs and markets is different." ${ }^{24}$

The Amsterdam Stock Exchange was the first official exchange. ${ }^{46}$ It was created in 1602 when Verenigde Ostindische Compagnie, the Dutch East India Company, decided to issue shares to finance its activities and needed an exchange to organise trading in its stocks and bonds. Generally, however, the initiative to create commercial exchanges of the first wave primarily came from traders. ${ }^{47}$

41 Wiener FA (1905) § 1 p 2.

42 For example, the fairs of Lyon started to compete against the fairs of Geneva in the $15^{\text {th }}$ century.

43 Van Alstyne MW, Parker GG, Choudary SP (2016).

44 Wiener FA (1905) § 4; Fleckner AM, Hopt KJ (2013) p 525. Fleckner and Hopt list the first commercial exchanges as follows: Bruges (1409), Antwerp (1460), Lyon (1462), Amsterdam (1530), Toulouse (1546), Cologne (1553), Hamburg (1558), Nuremberg (1560), Rouen (1566), London (Royal Exchange, 1570), Frankfurt (1585), Danzig (1593), Lübeck (1605), Königsberg (1613), Bremen (1614), and Leipzig (1635).

45 Vidal E (1910) p 5 on French commercial law.

46 European Central Bank (2007).

47 Fleckner AM, Hopt KJ (2013) p 525. 
While the exchanges of the first wave owed their existence to the initiative of traders, the exchanges of the second wave were driven by the mercantilist interests of the state. They were established and regulated by the state. ${ }^{48}$ This was the case with the bourses in Paris (1639/1724), Berlin (1685/1739), and Vienna (1771). ${ }^{49}$ The state had its own particular objectives in this context: "In historical perspective, state ownership of exchanges served the following two functions. (1) Governments had an interest in organizing a liquid secondary market in government securities. (2) Governments were interested in keeping a hand on a market which appeared as particularly vulnerable to fraud and manipulation by single market participants." 50

The third wave of exchanges followed industrialisation. This wave was fuelled by the funding needs of firms and the business interests of traders. The London Stock Exchange (1773) and the New York Stock Exchange (1792) belong to this group..$^{51} 1773$ was the year when brokers decided to form a club and open a formal Stock Exchange in London. Informal trading in London has longer roots, and traders had already persuaded Parliament to pass a clause preventing unchartered companies from forming. The start of the NYSE in 1792 meant 24 brokers trading a few stocks on Wall Street. ${ }^{52}$

The founding of exchanges was followed by the era of mutual stock exchanges. Typical stock exchanges were mutual associations owned by their members and operated on a not-for-profit basis. This was a successful organisational paradigm in the circumstances. ${ }^{53}$

Mutuality influenced the way different stock exchange functions were organised. For example, the official markets of the Paris Bourse were operated by the Compagnie des agents de change in the second half of the nineteenth century. There were 60 agents from 1816 to 1898 . All the agents were collectively responsible for the debts of any one of them and for the contracts made by any one of them on behalf of a seller. ${ }^{54}$ In other words, what would now be called a central counterparty function was allocated to the collective of agents. Moreover, traders negotiated directly with each other, and prices were quoted and changed by

48 Ibid., p 528.

49 Köndgen J (1998) p 228-230; Fleckner AM, Hopt KJ (2013) p 528.

50 Köndgen J (1998) p 241.

51 Fleckner AM, Hopt KJ (2013) p 533.

52 Mishkin FS, Eakins SG (2012) p 344. For the early history of NYSE, see Sylla R (2005).

53 Macey JR, O'Hara M (2005) p 572. For the Paris Bourse in the second half of the nineteenth century, see Walker DA (2001) pp 189-190.

54 Walker DA (2001) p 189. 
them..$^{55}$ This meant that the matching of orders and price discovery were allocated to traders rather than centralised. A degree of 7 October 1890 required that prices bid and asked for transactions for cash be written down in a special register and displayed. This led to the establishment of an "opposition service" in the cash market operated by the agents' clerks. In other words, the function of the dissemination of pre-trade information was allocated to the agents' clerks. ${ }^{56}$

The stock exchanges of these early waves hardly faced any competition. They were national or regional monopolies. ${ }^{57}$ This said, official markets could be complemented by unofficial markets. For example, in the second half of the nineteenth century, the official market of the Paris Bourse was complemented by an unofficial market called the coulisse. Agents therefore did not have a monopoly. ${ }^{58}$

Cross-border trading in shares was constrained by the available communication technology and limited by barriers to international capital movements.

Clearing and settlement. Increasing trading volumes made it necessary to centralise clearing and settlement functions.

The first organised securities clearing system was established in Frankfurt am Main in 1867. Other leading exchanges soon adopted the same practice in continental Europe. In the US, the first successful system was that of the Philadephia Stock Exchange. It began clearing in $1870 .^{59}$

Before 1892, the NYSE had no centralised clearing. All deliveries of shares and checks between brokers as well as between brokers and banks were handled individually by the parties. Since transactions required certifications from banks, banks had a high workload. According to Parker, "it was the threat of the bankers to shut down on certifications that finally induced the Exchange to institute a system of reducing totals to balances before settling". ${ }^{60}$ The NYSE established the Stock Clearing House in 1892. ${ }^{61}$

55 Ibid., p 194.

56 Ibid., p 201. For post-trade information, see p 204.

57 Macey JR, O’Hara M (2005) p 567.

58 Walker DA (2001) pp 189-191.

59 Parker W (1920) pp 16-17; Teweles RJ, Bradley ES (1998) p 317.

60 Parker W (1920) p 15.

61 Ibid., p 16. 


\subsubsection{Technology and the Move Towards Competition}

The available technology has always had an impact on trading practices. Technological advancement has had a critical impact on stock markets since the mid-nineteenth century. ${ }^{62}$ Early exchanges were designated physical locations where traders would meet at fixed times, because trading required visual and verbal interaction. ${ }^{63}$ The early exchanges were local, because trading participants had to be in the same place at the same time.

There were many local exchanges. ${ }^{64}$ At the turn of the millennium, most registered exchanges still operated floor-based systems with human intermediation of trading. ${ }^{65}$

However, there was a gradual move towards competition between exchanges. The emergence of competition between national exchanges coincided with advances in communications technology. ${ }^{66}$

This can be illustrated with the long history of the New York Stock Exchange (NYSE). Originally, the number of traders was small, the trading volumes were low, and the NYSE used call auctions. At the time, call auctions would not have been possible without the physical presence of traders in the same place at the same time. ${ }^{67}$ The NYSE ran a daily call auction for listed stocks from 1817 to 1869 . In the late 1860s, it had to adopt continuous auction trading as a means of accommodating larger numbers of stocks and traders in a single physical location. ${ }^{68}$ Sobel has described the NYSE's auction trading system as follows: "Prior to the Civil War, the Exchange had conducted its business through auctions ... Sellers would deposit their securities with the president prior to the auction, while buyers would await the call, and then bid against one another. This method suited small markets of the late eighteenth century, and so was carried over into the nineteenth. When business became hectic - such as after the discovery of gold in California in 1848, when mining shares were the rage - the

62 Domowitz I, Steil B (2002) p 315.

63 Steil B (2002a).

64 Fleckner AM, Hopt KJ (2013) p 535: "Prussia had the greatest influence on the development of German law in general and on stock exchange law in particular."

65 Domowitz I, Steil B (2002) pp 315-316.

66 Ibid., p 315.

67 Steil B (2002a).

68 Domowitz I, Steil B (2002) p 315; Schwartz RA (2001): “On May 8, 1869, the call procedure was abandoned when the NYSE merged with a competing exchange, The Open Board of Brokers, and became a continuous trading environment." 
Exchange would add a second auction. Sometimes this did not serve speculators and investors, who would gather near the Exchange to trade 'between calls'."69

The spread of telegraph technology reduced the need for independent centres of price formation and increased the dominance of the NYSE. Continued advances in communications technology led to further decline in the number of stock exchanges in the US, from over one hundred at the end of the nineteenth century to twenty-two in 1935, and only seven in $2002 .^{70}$

At the turn of the millennium, the basic structure of the NYSE's floor trading largely was the same as it had been since the 1870 s. $^{71}$ The nature of stock exchanges soon changed due to technological advancement.

It had become possible to match buy and sell orders on computer systems. Floor-based systems ${ }^{72}$ could be replaced by automated auctions that could attract an unlimited number of participants, remove geographical constraints, allow much higher trading volumes, and make it possible to develop new customised services. ${ }^{73}$ It is characteristic of automated systems that they either eliminate the intermediation of orders between the investor and the trading system (the brokerage function) or reduce it to ensuring that the investor has the requisite funds to buy or securities to sell (the electronic credit risk control function). ${ }^{74}$ First introduced in 1969, the continuous electronic auction market became the most common architecture for automated trading. ${ }^{75}$

This increased competition between stock exchanges. It was possible for issuers to apply for a listing in the home or host country, or multiple listings on several stock exchanges in the same country or different countries. Both issuers and investors asked for more liquid markets and lower costs. It could be achieved by increasing trading volumes and the number of issuers, by developing more attractive computer systems, and by adopting new exchange rules.

Moreover, alternative venues of trade execution began to compete with traditional exchanges. These venues competed on price and attracted price-con-

69 Sobel R (1977) p 28.

70 Domowitz I, Steil B (2002) p 315.

71 Ibid., p 316.

72 See, for example, Hardy CO (1939/1975) p 1: "On all of the important American stock exchanges the standard method of trading is through oral bids and offers made on the floor of the exchange, for blocks of stock of a specific size, which are known as 'round lots."

73 Allen H, Hawkins J, Sato S (2001) p 30.

74 Domowitz I, Steil B (2002) p 316.

75 Ibid., p 315. 
scious institutional investors with large trading volumes. ${ }^{76}$ The relative weight of institutional investors had grown (section 2.4.12).

\subsubsection{Market Liberalisation}

In addition to technology, the most important drivers of competition between exchanges in the second half of the twentieth century were integration, market liberalisation, ${ }^{77}$ and the creation of innovative financial instruments. ${ }^{78}$ In Europe, market liberalisation and increasing competition between stock exchanges were facilitated by the work of the OECD and by the regulatory framework of the internal market.

The OECD contributed to an increase in cross-border capital movements and investment. OECD members gradually liberalised cross-border capital movements. When the OECD was formed in 1961, it adopted two Codes of Liberalisation, namely the Code of Liberalisation of Capital Movements and the Code of Liberalisation of Current Invisible Operations. ${ }^{79}$ According to the Code of Liberalisation of Capital Movements, OECD members "shall progressively abolish between one another ... restrictions on movements of capital to the extent necessary for effective economic co-operation". ${ }^{00}$ Such "measures of liberalisation" cover both international direct investment and operations in securities on capital markets. ${ }^{81}$ Under the Code, an adhering country has a right to benefit from the measures of liberalisation of other adhering countries regardless of its own degree of openness. ${ }^{82}$ The Code prohibits discrimination. ${ }^{83}$

European integration increased cross-border capital movements in an internal market. The Treaty of Rome (the EEC Treaty, 1957) prohibited discrimination on grounds of nationality, liberalised the cross-border provision of services, and provided for the freedom of establishment. The internal market took a big step forward after the signing of the Treaty on European Union in Maastricht (the

76 Gadinis S, Jackson HE (2007) pp 1258-1259.

77 Fleckner AM (2006) p 2566: “The critical determinants are deregulation, technology, and globalization."

78 Christiansen H, Koldertsova A (2009) p 221: "In addition to the obvious effects of demutualisation and listing of exchanges, a rapid improvement in information technology and the creation of innovative financial instruments have also been among the key factors."

79 See OECD (2011). For the role of the IMF, see Chwieroth JM (2010).

80 Article 1(a) of the OECD Code of Liberalisation of Capital Movements.

81 Ibid., Annex I.

82 Ibid., Article 8.

83 Ibid., Article 9. 
EU Treaty, 1992). The Maastricht Treaty introduced the free movement of capital as a Treaty freedom. ${ }^{84}$ The European Commission's Financial Services Action Plan (the FSAP) had as its object the creation of an integrated capital market by 2005. The FSAP consisted of an ambitious programme of rules for the financial industry ${ }^{85}$ based on the principles of non-discrimination, mutual recognition, one-stop shop, and home country control. The introduction of the Investment Services Directive (ISD) ${ }^{86}$ made it possible for EU-based investment firms to provide services in other Member States (host countries) after obtaining a home country authorisation. ${ }^{87}$ It was no more necessary for an investment firm to be physically present in a host country for trading purposes. The ISD increased cross-border price competition between exchanges. To reduce costs, exchanges invested in electronic trading systems and increased economies of scale through exchange mergers and the combination of equity and derivatives markets. ${ }^{88}$ Treaty provisions have now been consolidated in the Treaty on European Union and the Treaty on the Functioning of the European Union (the TEU and TFEU, 2012). ${ }^{89}$

Moreover, there was increasing convergence of the regulation of exchanges and capital markets between the EU and the US. In the US, the Glass-Steagall Act was repealed in 1999, increasing the size of US banks and making them more competitive in the domestic and global marketplace. The extraterritorial reach of the Sarbanes-Oxley Act of 2002 made it necessary for the EU to align European regulation with that of the US. ${ }^{90}$ The European Commission's 2003 Company Law Action Plan ${ }^{91}$ focused on corporate governance, among other

84 Today, Article 63 of the TFEU prohibits all restrictions on the movement of capital and payments between Member States, as well as between Member States and third countries.

85 See, for example, Moloney N (2004).

86 Council Directive 93/22/EEC of 10 May 1993 on investment services in the securities field (ISD).

87 See, for example, Warren MG (1994); Demarchi M, Foucault T (2000).

88 Demarchi M, Foucault T (2000).

89 The geographical area of European market integration is larger than the EU. The rules facilitating an internal market were adopted by the members of the European Free Trade Association (EFTA). The legal framework facilitating the integration of the EEC and EFTA created the European Economic Area (EEA Treaty, 1993). Most EFTA countries have joined the EU and the EFTA consists of just four countries at the time of writing. Iceland, Lichtenstein, Norway, and Switzerland are EFTA members that have not joined the EU. The UK is a former EFTA member. The UK decided to leave the EU in 2020.

90 See, for example, Mäntysaari P (2005) section 3.2.3.

91 Modernising Company Law and Enhancing Corporate Governance in the European Union A Plan to Move Forward. Communication from the Commission, COM(2003) 284 final. 
things. ${ }^{92}$ The 2009 Pittsburgh agreement of G20 leaders focused on OTC contracts. ${ }^{93}$ The general regulatory goal of the Pittsburgh agreement was to improve transparency in the derivatives markets, mitigate systemic risk, and protect against market abuse. ${ }^{94}$ In banking, the Basel Committee on Banking Supervision produced a framework to strengthen the regulation, supervision and risk management of the banking sector. The most recent Basel framework is called Basel III.

The approximation of the regulation of capital markets and financial services in the EU and the convergence of regulation in the EU and the US were followed by the increased internationalisation of the financial industry. In the EU, new rules facilitated the provision of cross-border financial services, the establishment of branches and subsidiaries in other Member States, as well as cross-border mergers and acquisitions. The launch of the euro abolished currency risk in the euro area and accelerated the shift from country-based portfolio management to international sector-based investment. ${ }^{95}$

\subsubsection{Demutualisation, IPOs and Concentration}

The basis of mutual stock exchanges gradually eroded due to the emergence of competition between exchanges. Not all stock exchanges survived as autonomous entities. The stock exchanges that survived had chosen to act as normal commercial enterprises (firms) after demutualisation. ${ }^{96}$ Moreover, they became listed companies with their own market investors.

92 Hopt KJ (2019a) II.3(c): "As to the content of the Action Plan, which follows the recommendations of the High Level Group almost completely, six broad areas are covered: (1) corporate governance; (2) the raising and maintenance of legal capital; (3) groups of companies; (4) restructuring; (5) new European company forms, such as the European private company as well as other enterprise and foundation forms; and (6) transparency of national legal forms. The main concern of the Commission is certainly corporate governance. This is a remarkable shift from classical company law to corporate governance, though upon closer examination key company law problems have been tackled in the Action Plan in a functional, modern way."

93 Recital 5 of Regulation 648/2012 (EMIR).

94 In the US, derivatives regulation was strengthened by the Dodd-Frank Wall Street Reform and Consumer Protection Act. In the EU, it was done by Regulation 648/2012 (EMIR). See recitals 7 and 8 of EMIR.

95 Steil B (2001) p 335.

96 For demutualization generally, see Fleckner AM (2006) p 2542. For demutualization in the US, see Fleckner AM (2006) pp 2557-2558. For the interests of firms generally, see Mäntysaari P (2012) Chapter 4; Mäntysaari P (2017) section 7.5.5. For the sources of revenues of stock exchanges, see Fleckner AM (2006) pp 2549-2550. 
Demutualisation. The drivers of competition acted as drivers of demutualisation. Generally, growing inter-exchange competition should have the effect of increasing the prevalence of for-profit exchanges. ${ }^{97}$ Since the fundamental driver was competition for global order-flow, demutualisation spread from developed markets to emerging markets. ${ }^{98}$

Demutualisation meant more than replacing a mutual association that operated an exchange with a limited-liability company doing the same thing. This was because of the different economics of the business of mutual associations and automated auction trading, and because of the resulting governance problems of mutual associations. The introduction of limited-liability companies as exchange operators changed the business of exchange operators.

The traditional model of an exchange used to be a locally organised mutual association. It was a remnant of the era before trading system automation when access to the exchange had to be rationed to prevent overcrowding, and when exchanges as cooperatives were naturally run by the traders themselves. ${ }^{99}$ These mutual associations charged membership fees, and the value of an exchange derived from the physical presence of traders. ${ }^{100}$ Over time, the actual costs of running the exchange were largely shifted to listed companies, leaving the members free to extract rents. ${ }^{101}$

In contrast, access to computer systems does not have to be limited to a certain location or by the number of access points. Since the marginal cost of adding a member to a trading network declines towards zero, fixed access costs (membership fees) tend to be replaced by variable costs (transaction-based charging). This makes the operation of an electronic auction system more like the provision of a normal for-profit service. ${ }^{102}$

The traditional business model of mutual associations thus had significantly higher trading costs to investors and higher capital costs to listed companies. ${ }^{103}$ This contributed to conflicts of interest between the exchange and its traditional members as well as between its members inter se.

Conflicts of interest between the exchange and its traditional members were caused by four things. First, to survive, the operators of stock exchanges turned into normal commercial firms that treated exchanges as normal commercial

97 Hart O, Moore J (1996); Steil B (2002a).

98 IOSCO (2005) pp 6-7.

99 Steil B (2002a).

100 Ibid.

101 Macey JR, O’Hara M (2005) p 572.

102 Steil B (2002a).

103 Steil B (2001) pp 332-333. 
business assets. The operators of stock exchanges became firms that provided technology and information services to customers. Second, the threat of competition forced each exchange operator to invest in an electronic trading system. Each operator tended to build its own proprietary system. ${ }^{104}$ Third, these electronic auction systems were regarded as service platforms that could be made available to new customers. For the operator of an exchange, large investments in an electronic trading system would not have been meaningful without the prospect of increased trading and fees through organic growth, licensing, and mergers. Fourth, traditional brokers had an incentive to block this development to protect their own business interests.

The primary function of demutualisation was to reduce the control of intermediaries over the strategic positioning of the exchange. ${ }^{105}$ In a mutual association, exchange members derive profits from intermediating non-member transactions. Investors and issuing companies can suffer significant economic costs from inefficient trading structures and excess intermediation. ${ }^{106}$ Trading volumes can be increased by reducing these costs. ${ }^{107} \mathrm{~A}$ major economic benefit of automated auction trading is the elimination of the need for such trade intermediation. ${ }^{108}$ Because of conflicts of interest, mutual associations could have difficulties introducing automated systems and allowing their full potential to be exploited by non-member investors. ${ }^{109}$ For example, it was typically the smaller members, such as floor brokers on the NYSE or the hoekman (specialists) on the Amsterdam Stock Market, that had the most to lose and therefore resisted demutualisation. ${ }^{110}$ The largest UK-based market makers of the London Stock Exchange fought to block the adoption of electronic auction trading as late as in the mid-1990s. ${ }^{111}$

There were also conflicts of interest between local exchange members that did not want a change and large international trading houses that did. While locals had "a strong incentive to maintain institutional barriers to disintermediation of their services", larger international players tended to see the introduction

\footnotetext{
104 Ibid., pp 340-341.

105 Steil B (2002a).

106 Steil B (2001) pp 332-333 and 341.

107 Ibid., p 342.

108 Ibid., p 332.

109 Steil B (2002a).

110 Ferrell A (2007) p 8

111 Steil B (2002a); Steil B (2001) p 332.
} 
of trading automation and a governance reform as "an effective weapon for increasing their strategic control of the exchange vis-à-vis the locals". ${ }^{112}$

Moreover, there were conflicts of interest between international players and local exchanges. International players were members of numerous exchanges and had to pay multiple membership fees. They were in favour of consolidation for various reasons. The direct costs of multiple memberships could be reduced by making stock exchanges merge. ${ }^{113}$ Cross-border settlement costs could be reduced by consolidating systems or through cross-border exchange mergers. ${ }^{114}$ The costs of each stock exchange and each membership could be reduced by consolidating the trading systems. It made no economic sense to build separate and unique trading systems for exchanges that applied the same market architecture: "With few exceptions, fledgling exchanges should find it most cost-effective to buy, lease, or pay for access to trading and settlement systems already in operation elsewhere." 115 Large international trading houses that were members of many stock exchanges could also increase their control of an exchange through demutualisation and mergers.

The development of demutualised, commercial, and for-profit system operators became the norm. ${ }^{116}$ The first stock exchange to demutualise was the Stockholm Stock Exchange in 1993. ${ }^{117}$

Stock exchange IPOs. Obviously, stock markets needed a new governance model to solve the conflict between the interests of the operator of the stock exchange and the interests of its members. There were even other reasons to improve the governance model. The nature of the business required faster and better decision-making processes supported by a more efficient corporate governance model. This required more than the mere choice of the business form of a limited-liability company.

After the demutualisation of the exchange, earlier member firms still held significant share blocks in the operator of the stock exchange. The reorganisation of exchanges as limited-liability companies was complemented by initial public offerings (IPOs) and self-listings. ${ }^{118}$ The self-listing of the operator of the stock exchange made it possible for non-members to buy equity stakes in the exchange operator, facilitated a more dispersed share ownership structure, and helped to

112 Steil B (2002a).

113 Steil B (2001) p 335.

114 Ibid., p 335.

115 Ibid., pp 340 -341.

116 Ibid., p 339.

117 IOSCO (2001) pp 21-22.

118 Macey JR, O’Hara M (2005) p 574 and Table 1 on pp 594-595; Köndgen J (1998) p 233. 
separate the interests of the exchange operator from those of trading houses. This changed the incentive structure, ${ }^{119}$ separated ownership from control, ${ }^{120}$ and created a takeover market for exchanges. ${ }^{121}$

Whether exchange members were prepared to accept new investors tended to depend on "the degree of competition, or potential competition, which the exchange face[d], and the degree to which the largest member firms operate[d] internationally". ${ }^{122}$ While the pioneer demutualisers operated in small and highly open national economies, there was a clear global trend towards exchange demutualisation and listing. ${ }^{123}$ Most stock exchanges in OECD countries demutualised and self-listed. ${ }^{124}$

Concentration. After the demutualisation of exchanges and the IPOs of exchange operators, it was time to focus on scale and scope. Concentration is a question of scale. Diversification is a question of scope. ${ }^{125}$

The demutualisation of stock exchanges was followed by the question of scale, that is, the concentration of exchanges nationally ${ }^{126}$ as well as through cross-border cluster-building ${ }^{127}$ and mergers.

The concentration of exchanges was made much easier by self-listings. ${ }^{128}$ It was now technically possible to make a public bid for shares in the operator of a stock exchange, and to merge exchange operators. ${ }^{129}$

119 Steil B (2002a).

120 Fleckner AM (2006) p 2576.

121 Macey JR, O’Hara M (2005) p 574. For the market for corporate control generally, see Manne HG (1965).

122 Steil B (2002a).

123 Steil B (2002a): "It is not surprising that the pioneer demutualizers were three Nordic exchanges and Amsterdam. These exchanges operate in small and highly open national economies." For a list of stock exchanges to demutualise and go public, see, for example, Ferrell A (2007).

124 Christiansen H, Koldertsova A (2009) pp 219-220.

125 For the scale and scope of fund management companies, see Morley J (2014) p 1259.

126 Steil B (2001) pp 347-348: "Despite growing concern among European exchanges and regulators over ECNs and trading fragmentation, European share trading is actually more concentrated than it has been at any time over the past fifteen years (since the launch of London's SEAQ International).” Macey JR, O’Hara M (2005) p 567: “[E]xchanges have often enjoyed monopoly status whereby they are the only firm producing such exchange services, at least over some geographical or national boundary."

127 See Floreani J, Polato M (2013) p 182.

128 Ferrell A (2007) p 9.

129 Christiansen H, Koldertsova A (2009) p 255: "Stock exchange consolidation has been ongoing for decades, but the transformation of exchanges into listed companies has unleashed a new wave of mergers and acquisitions (M\&A) - and has added a strong cross-border dimension. The 
The concentration of exchanges was driven by the predominance of fixed costs, the existence of positive network effects with liquidity as an important goal, ${ }^{130}$ and increasing regulation.

The high proportion of fixed costs and the low proportion of variable costs made running a stock exchange one of the best examples of economies of scale. ${ }^{131}$

There could be positive network effects, because each trader brought additional trading opportunities and liquidity, making the network more attractive and implying a tendency to consolidation. ${ }^{132}$ Moreover, there could be positive network effects unrelated to liquidity. For example, location is seen as important for traders since "proximity allows for cheap and easy exchange of information with other traders, analysts and the sales force". This helps to explain why London experienced rapid growth in financial service employment between 2001 and 2006, while Amsterdam and Frankfurt experienced a gradual decline. Generally, a lot of financial work moved to the leading financial centres London and New York. ${ }^{133}$

Moreover, concentration was driven by increased use of clearing obligations, increased use of central counterparties, increased capital requirements

combination of NYSE and Euronext in 2006, Nasdaq's acquisition of the OMX and Bourse Dubai's investment in Nasdaq in 2007, Qatar's investment in the London Stock Exchange and the latter's merger with Borsa Italiana in 2007 provide just a few examples of the dramatic restructuring of the industry. Industry consolidation appears to be continuing, especially in North America and Europe.”

130 Fleckner AM, Hopt KJ (2013) pp 554-556: "Until one decade ago, other marketplaces failed to win considerable trading volume from the traditional exchanges. The 'network effect' explains why: the more liquid a marketplace is, the lower the transaction costs are, and the lower the transaction costs are, the more attractive and thus more liquid the market is."

131 Fleckner AM (2006) pp 2577-2578: "Once an exchange has set up the trading facilities (such as floors and electronic systems), drafted the rules, formulated the corporate governance standards, and so forth, there are almost no further costs, regardless of the number of transactions performed at the exchange ... If two exchanges merge, they can almost halve most of their fixed expenses, like updating the trading system and reviewing their rules and corporate governance standards."

132 Allen H, Hawkins J, Sato S (2001) pp 33 and 37-38; Fleckner AM, Hopt KJ (2013) pp 554556. See even Bagheri M, Nakajima C (2004) p 94 on exchanges as natural monopolies: "If exchanges are natural monopolies, i.e. there are economies of scope and scale in trading and settlement activities of the securities markets, then there is a question of how far the application of competition laws should be pursued."

133 Engelen E, Grote MH (2009) p 682. 
for investment firms, ${ }^{134}$ and generally by the increased regulation of exchanges. Regulatory compliance became one of the core competences of exchanges. ${ }^{135}$ The cross-border consolidation of stock exchanges increased entry barriers by increasing the cost of regulatory compliance for new cross-jurisdictional entrants. ${ }^{136}$

The concentration of intermediaries increased the internal execution of client orders within investment firms. At the turn of the millennium, many large institutions were internalising between $15-30 \%$ of client order flow in European jurisdictions that had not introduced the "concentration rule"137 (section 3.3.3). ${ }^{138}$

\subsubsection{Fragmentation and Diversification}

Concentration was followed by fragmentation. At the turn of the millennium, digitalisation and network effects had contributed to the concentration of stock exchanges. Fragmentation had only had a limited impact on market structures. ${ }^{139}$ Ten years later, the situation had changed. New rules had facilitated the emergence of alternative trading venues. Trading commissions were brought down by technological advancement and competition. New rules, new marketplaces, and technological advancement attracted high frequency traders. ${ }^{140}$

Fragmentation. The emergence of alternative trading venues increased the fragmentation of trading systems and reduced the efficiency of price forma-

134 Section A of Annex I to Directive 2004/39/EC (MiFID) and Directive 2014/65/EU (MiFID II); Articles 4 and 16 of Regulation 648/2012 (EMIR).

135 Christiansen H, Koldertsova A (2009) p 220.

136 See ibid., p 226.

137 Article 14(3) of Directive 93/22/EEC (ISD).

138 Proposal for a Directive of the European Parliament and of the Council on investment services and regulated markets, COM/2002/0625 final, section II.1: "The following technology-driven trends have transformed the financial trading landscape: 1 . inter-exchange competition ... 2. competition from alternative trading systems ... 3. increased internal execution of client orders within investment firms ... A diminishing balance of retail investor orders which cannot be executed internally is routed to exchanges for execution. This practice is well established in jurisdictions which have not introduced a 'concentration rule' ...”

139 Steil B (2001) pp 347-348: "Despite growing concern among European exchanges and regulators over ECNs and trading fragmentation, European share trading is actually more concentrated than it has been at any time over the past fifteen years ...” Fleckner AM, Hopt KJ (2013) pp 554-556: "Until one decade ago, other marketplaces failed to win considerable trading volume from the traditional exchanges. The 'network effect' explains why ..."

140 Fioravanti SF, Gentile M (2011) p 5. 
tion: ${ }^{141}$ "Two examples illustrate the tremendous pace of change: At the end of 2005, it was a widely recognized event that the New York Stock Exchange's market share in the trading of securities whose issuer is primarily listed in New York dropped below $75 \%$, the lowest level since the beginning of the recording of this data three decades ago. Less than three years later, in summer 2008, the New York Stock Exchange's market share stood at a mere 25\%. The London Stock Exchange's market share in the United Kingdom fell between January and October 2008 from $96 \%$ to $58 \%$, recovered in 2010 to some $62 \%$, before it dived below $50 \%$ in 2011."142

In other words, traditional stock exchanges were "no longer the place where traders conduct most of their transactions". ${ }^{143}$

In 2010, the SEC described the US market structure as "dispersed and complex: (1) Trading volume is dispersed among many highly automated trading centers that compete for order flow in the same stocks; and (2) trading centers offer a wide range of services that are designed to attract different types of market participants with varying trading needs." 144

In other words, the earlier oligopoly dominated by Nasdaq and the New York Stock Exchange was gone as far as trading was concerned. ${ }^{145}$ According to a 2019 book, "any given [American] stock is potentially traded in each of almost seventy-five competing venues, including twelve exchanges and more than thirty dark pools". ${ }^{146}$ Lewis wrote in 2015 that "the banks had managed to move 38 percent of the entire U.S. stock market now traded inside their dark pools" and that "[i]t is a façade that the market is interconnected". ${ }^{147}$

According to the SEC, "[a] primary driver and enabler of this transformation of equity trading has been the continual evolution of technologies for gen-

141 Ibid., p 5; Fleckner AM, Hopt KJ (2013) pp 555.

142 Fleckner AM, Hopt KJ (2013) pp 554-556. See also Gadinis S (2008) pp 317-318; SEC Release No. 34-61358 (Jan. 14, 2010) (Concept Release on Equity Market Structure), section I.

143 Fleckner AM, Hopt KJ (2013) p 559.

144 SEC Release No. 34-61358 (Jan. 14, 2010) (Concept Release on Equity Market Structure), section I.

145 For IPOs, see Morrison \& Foerster LLP (2017) pp 1 and 5: "[W]e examined the filings of (i) the approximately 680 EGCs (on an aggregated basis) that completed their IPOs in the period from January 1, 2013, through December 31, 2016, and (ii) the 100 EGCs (on a standalone basis) that completed their IPOs during the year ended December 31, 2016. [...] Of the 680 EGCs, all but two were listed on markets within the Nasdaq Stock Market ('Nasdaq') or the New York Stock Exchange (NYSE').”

146 Fox MB, Glosten LR, Rauterberg GV (2019) p 13. See also Gadinis S (2008) p 321; Lewis M (2015) pp 134-135.

147 Lewis M (2015) p 211. 
erating, routing, and executing orders. These technologies have dramatically improved the speed, capacity, and sophistication of the trading functions that are available to market participants." ${ }^{148}$ Moreover, the SEC explained that changes in market structure reflected "the markets' response to regulatory actions such as Regulation NMS, adopted in 2005, the Order Handling Rules, adopted in 1996, as well as enforcement actions, such as those addressing anti-competitive behavior by market makers in NASDAQ stocks." ${ }^{149}$ Regulation NMS is generally regarded as a piece of regulatory action that "stimulated a huge amount of stock market trading". 150

The emergence of a greater level of trading fragmentation in the US than in Europe was caused by a consolidated market data system, the "Order Protection Rule", and a greater centralisation of clearing flows in the US. ${ }^{151}$

The trend of fragmentation has not stopped. In 2019, some of Wall Street's largest brokers and banks gave their backing to Members Exchange or MEMX, a new stock exchange that aims to break the dominance of the New York Stock Exchange and Nasdaq by reducing the overall costs of trading. MEMX said it would offer lower pricing on market data, connectivity and transaction fees. ${ }^{152}$

Diversification. Fragmentation influenced the choice between the scale and scope of a stock exchange. Diversification is a question of scope. Demutualisation and the listing of stock exchanges were followed by the increased diversification of their business. ${ }^{153}$ The drivers were increased competition ${ }^{154}$ and the new nature of the stock exchange business.

148 SEC Release No. 34-61358 (Jan. 14, 2010) (Concept Release on Equity Market Structure), section I.

149 Ibid. See also Adrian J (2015-2016) p 257: "This fragmentation was further driven by SEC instituted regulations that were designed to foster competition between the exchanges after their privatization in 2005, known as Regulation NMS, or National Market System. SEC regulation spread the market out, while changes in technology ballooned the amount of trading and greatly increased the speed at which it could be done."

150 Lewis M (2015) pp 134-135.

151 Fioravanti SF, Gentile M (2011) p 14; Mahoney PG, Rauterberg GV (2018).

152 Philip Stafford and Nicole Bullock, Wall Street heavyweights back new exchange rival to NYSE, Nasdaq. Financial Times, 7 January 2019; Philip Stafford, BlackRock throws support behind US exchange start-up MEMX. Financial Times, 12 May 2020.

153 See how Deutsche Börse AG and London Stock Exchange Group are described in paragraphs 2-3 and 25-26 of Commission Decision of 29 March 2017 declaring a concentration to be incompatible with the internal market and the functioning of the EEA Agreement (Case M.7995- Deutsche Börse / London Stock Exchange).

154 Christiansen H, Koldertsova A (2009) p 221. 
Competition was intensified by a rapid improvement in information technology, ${ }^{155}$ the creation of innovative financial instruments, ${ }^{156}$ and the expansion of derivatives exchanges and commodities exchanges.

Market participants could trade in stocks by using functional equivalents to trading in stocks: "A holder of a portfolio of common stocks may, by selling an index futures contract, achieve the functional equivalent of selling off the stock and investing the proceeds in Treasury Bills or some equivalent instrument. Buying futures contracts when stocks are already owned in a portfolio is equivalent to margining that portfolio and selling short-term debt instruments and investing the proceeds in stocks." 157

Therefore, stock exchanges had reason to regard derivatives exchanges and commodities exchanges as potential competitors. After the turn of the millennium, the largest derivatives exchanges were either already publicly-listed companies, or part of publicly-listed parent companies, or demutualised and went public. ${ }^{158}$

Exchanges were now increasingly seen as providers of various kinds of specialist services in competitive markets. ${ }^{159}$ From the perspective of the operator of a stock exchange, its business did not need to be limited to what was regarded as the main of role of stock exchanges in the past: the matching of buyers and sellers of securities and the provision of a mechanism for price discovery. ${ }^{160}$ Each firm could choose its own business model. The operators of stock exchanges became suppliers of technology and information services. In addition, they could provide the matching of bids, clearing, and settlement services. ${ }^{161}$

155 See, for example, Lee R (1998) p 4; Baum H (2004) pp 680-681: "Instead of exchanges being natural monopolies, we are seeing a fierce competition between traditional exchanges and a plethora of newly developed electronic facilities offering various exchanges services. These platforms are increasingly making use of Internet technology.”

156 Christiansen H, Koldertsova A (2009) p 221.

157 Friedland JH (1994) p 122.

158 Ferrell A (2007).

159 Bagheri M, Nakajima C (2004); Christiansen H, Koldertsova A (2009).

160 For the definition of an exchange in the US, see section 3(a)(1) of the Securities Exchange Act of 1934. For an example of the traditional view on stock exchanges, see Fleckner AM (2006) p 2546.

161 Ben Slimane F (2012); Bagheri M, Nakajima C (2004); Christiansen H, Koldertsova A (2009); Floreani J, Polato M (2010) p 30: "Since maintaining the competitive advantage in the securities industry depends on the ability of exchanges to strengthen their relations with clients, gaining access to a wide set of business areas qualifies as a strategic goal. As a result, major exchanges not only manage trade execution services but provide to users a wide set of services related to the investment in financial products." See also Regulation (EU) No 648/2012 of the European 
The changing nature of the business of stock exchange operators can be illustrated with how Nasdaq, Inc. described its business in a SEC filing in 2019: "We are a leading provider of trading, clearing, marketplace technology, regulatory, securities listing, information and public and private company services. Our global offerings are diverse and include trading and clearing across multiple asset classes, trade management services, market data products, financial indexes, investment data and analytics, capital formation solutions, corporate solutions, and market technology products and services. Our technology powers markets across the globe, supporting equity derivative trading, clearing and settlement, cash equity trading, fixed income trading, trading surveillance and many other functions. We manage, operate and provide our products and services in four business segments: Market Services, Corporate Services, Information Services and Market Technology." 162

Reduced relevance of listings. The changing nature of the business of exchange operators influenced the definition of the regulatory term "exchange" in the US (Regulation ATS) ${ }^{163}$ and the EU (MiFID II). ${ }^{164}$ Even the role of listings changed for exchanges.

Parliament and of the Council of 4 July 2012 on OTC derivatives, central counterparties and trade repositories.

162 Nasdaq, Inc., Form 10-Q for the quarterly period ended March 31, 2019, Part I, Item 2. 163 SEC Release No. 34-40760 (Regulation of Exchanges and Alternative Trading Systems). Regulation ATS, section II.A: "A fundamental component of the new regulatory framework is new Rule 3b-16. This rule interprets key language in the statutory definition of 'exchange' under section 3(a)(1) of the Exchange Act. Rule 3b-16 reflects a more comprehensive and meaningful interpretation of what an exchange is in light of today's markets. Until now, the Commission's interpretation of the exchange definition reflected relatively rigid regulatory requirements and classifications for 'exchange' and 'broker-dealers.' Advancing technology has increasingly blurred these distinctions, and alternative trading systems today are used by market participants as functional equivalents of exchanges ... The statutory definition of 'exchange' includes a 'market place or facilities for bringing together purchasers and sellers of securities or for otherwise performing with respect to securities the functions commonly performed by a stock exchange.' In response to commenters' concerns and suggestions, the Commission has carefully revised Rule 3b-16 to define these terms to mean any organization, association, or group of persons that: (1) brings together the orders of multiple buyers and sellers; and (2) uses established, non-discretionary methods (whether by providing a trading facility or by setting rules) under which such orders interact with each other, and the buyers and sellers entering such orders agree to the terms of a trade."

164 See points (18)-(24) of Article 4(1) of Directive 2014/65/EU (MiFID II) defining the notions of "market operator", "multilateral system", "systematic internaliser", "multilateral trading facility” (MTF), “organised trading facility” (OTF), and "trading venue”. A "trading venue” means a regulated market, an MTF or an OTF. 
There are exchanges with listings of companies and exchanges without such listings. In the US, exchanges "can trade any stock, wherever it is listed; indeed few do listings at all”. ${ }^{165}$ Investors Exchange (IEX) is an example of a successful exchange that has no listings but in 2009 traded "6,000-7,000 stocks and exchange-traded funds each day, making it the world's seventh largest ecxhange operator by trading value". ${ }^{166}$

Reduced relevance of liquidity. The declining relevance of listings was accompanied by the changing relevance of liquidity. Liquidity obviously matters for investors. The role of liquidity for stock exchanges changed due to technological advancement and regulatory change. US regulatory changes reduced liquidity for institutional investors. ${ }^{167}$

The parallel trends of inter-exchange competition and competition from alternative trading systems contributed to the increased concentration of intermediaries and the internal execution of client orders within intermediaries. ${ }^{168}$ While the functions of market intermediary and marketplace had historically been performed by distinct types of institution, the boundary between marketplaces and intermediaries became blurred after the turn of the millennium.

Moreover, the fragmentation of trading, the rise of dark pools, and the diversification of stock exchanges' activities made transparency and "liquidity" less important for stock exchanges. ${ }^{169}$

According to a study, the competitive advantage of a stock exchange is based on three factors: a) a diversified business model that reduces the volatility of its own revenues; b) governance arrangements that affect the incentives of the operator company's management; and c) large trading volumes and a large number of securities admitted to trading. ${ }^{170}$

Obviously, the profits of a stock exchange are higher if it has attracted more listings and the volume of trading is higher. A stock exchange can charge fixed fees for listings and variable fees for transactions. However, digitalisation has brought down fixed costs and transaction costs, and US regulation permits ex-

165 The Economist, Flash boys in the pan, 28 September 2019.

166 Ibid.

167 Gadinis S (2008) pp 315-316.

168 Proposal for a Directive of the European Parliament and of the Council on investment services and regulated markets, COM/2002/0625 final, section II.1.

169 See, for example, Fioravanti SF, Gentile M (2011) p 14: "Competition among trading venues can reasonably improve broker and institutional investor's operability because it brings down the average level of fees and because it enlarges exchange services offer. However, it is difficult to exactly quantify investor's net benefits because the spreading out of dark pools and high frequency trading could weaken market efficiency and could raise transparency issues ...”

170 Floreani J, Polato M (2010) p 32. 
changes to trade any stock listed in the US. Stock exchanges have incentives to compete for trading volumes. The market trend is towards inequalities in trading options and heterogeneous pricing. ${ }^{171}$

In fact, there is a new revenue model in the US equities markets: "The predominant model that has emerged in the U.S. equities markets is the 'makertaker' fee model, in which, on the one hand, a trading center pays its brokerdealer participants a per share rebate to provide (i.e., 'make') liquidity in securities and, on the other hand, the trading center assesses them a fee to remove (i.e., 'take') liquidity." 172 The maker-taker pricing model reflects the economics of two-sided network effects ${ }^{173}$ and "originated on electronic communications networks (ECNs) in the late 1990s as ECNs attempted to attract order flow and draw liquidity from traditional exchanges by offering rebates to market participants that posted liquidity to their platforms."174

For example, until 2006, the NYSE operated as a not-for-profit enterprise that focused on listing companies and facilitating stock trading. It used to generate revenue mostly from listing and trading fees. In 2018, volume is critical for the NYSE. The NYSE pays rebates to high-frequency traders and brokers to place trades on the exchange. The NYSE charges HFTs for high-speed data feeds and the right to locate their computers in close physical proximity to the exchange's computers. ${ }^{175}$

The emergence of many alternative venues (section 3.3) indicates that liquidity is not the driving force in the development of stock exchanges. ${ }^{176}$ This is even

171 Fleckner AM, Hopt KJ (2013) pp 554-556. See also Lewis M (2015).

172 SEC Release No. 34-82873 (Transaction Fee Pilot for NMS Stocks), section II.A.

173 Van Alstyne MW, Parker GG, Choudary SP (2016).

174 SEC Release No. 34-82873 (Transaction Fee Pilot for NMS Stocks), section V.A.1.

175 David Swensen, High frequency trading: NYSE is putting its own interest ahead of investors'. Financial Times, 12 August 2018. See also Rule 610T of Regulation NMS.

176 See, for example, Macey JR, O'Hara M (2005) p 565: “A particular thesis we develop is that shifts in transaction costs and agency costs have dictated changes in the optimal economic organization of trading. These changes have forced economic activity to migrate from a centralized market to multiple competing venues. We argue that these shifts, in turn, have changed the optimal ownership structure of exchanges, pushing exchanges away from a cooperative structure to a corporate structure." Fleckner AM, Hopt KJ (2013) pp 554-556: "It took some time until observers began to appreciate the negative consequences of the ongoing market fragmentation, such as heterogeneous pricing (instead of central price fixing at the exchange), intransparency (caused by 'dark pools' and other forms of hidden trading), or inequalities in the trading options (that give certain professional traders advantages over other investors).” Lewis M (2015) p 159: "Why didn't investors organize themselves to sponsor a single stock exchange entrusted with guarding their interests and protecting them from Wall Street predators?” 
more so in Europe where competition was increased and trading on opaque markets fostered by MiFID II. ${ }^{177}$ European markets are more fragmented than US and Asian markets: “The proportion of trading on 'lit venues' is much lower in Europe than in the US and Asia, which provides a clear indication of how fragmented and opaque markets are in Europe." ${ }^{178}$

\subsubsection{Conclusion}

The history of stock exchanges shows that the structure of stock markets is not written in stone. The long-term trend is structural change driven by technological advancement, the interests of financial intermediaries, and regulatory change. The interests of issuer-firms have mattered very little in this process. Failure to take into account the interests of issuer-firms could be one of the causes of low IPO levels. The evolution of stock exchanges does not stop here. In the next section, we can have a look at the function and regulation of alternative venues.

\subsection{Alternative Venues in General}

\subsubsection{General Remarks}

If stock exchanges are not designed with the interests of issuer-firms in mind, you might need alternative venues that work better for issuer-firms. But such alternative venues have not yet emerged. Most alternative venues have not been designed to benefit issuer-firms. SME exchanges may be the exception confirming the rule (section 3.5). This said, the evolution of the regulation of alternative venues can be relevant where the goal is to propose future regulation. It can help to understand what seems to be the problem and to what extent the current regulatory regime leaves room for new kinds of venues.

The emergence of alternative venues for trade execution can be illustrated with the history of the NYSE that even includes the specialist system, OTC dealers, odd-lot dealers, and adapting to Regulation NMS.

In the latter half of the nineteenth century, the NYSE was complemented by the specialist system and the Open Board that was organised by traders who had

177 FESE (2019) p 32.

178 Ibid., p 33. 
been excluded from the NYSE: "By 1866 some brokers took to stationing themselves at the centers of the various crowds, and would remain there throughout the day, dealing in only one stock. Would-be buyers and sellers knew who they were and would come to them for quotes. Thus was born the specialist system, the heart of the Open Board and a rival method to the auctions ..."179

The NYSE's specialist system had flaws that were revealed by block trades. ${ }^{180}$ After the beginning of World War II, NYSE specialists were unable to help European investors and government sell large blocks of shares. ${ }^{181}$ In the 1950s and 1960s, the number of block trades increased as institutions came to dominate trading. ${ }^{182}$ OTC dealers filled the gap. ${ }^{183}$

Moreover, the NYSE'S market for "round lots" was complemented by a market for "odd lots". ${ }^{184}$ On the NYSE, the bulk of the odd-lot trade was done for many years by three large dealer firms known as odd-lot houses. ${ }^{185}$ An alternative could have been a secondary auction market with a 1-share unit of trading ${ }^{186}$ or at least a small unit of trading. ${ }^{187}$

179 Sobel R (1977) pp 28-29.

180 Ibid., p 222. See also p 54: "The specialist system demonstrated an inability to wed block trading and public responsibility. This became evident when several institutions tried to unload their shares at the same time."

181 Ibid., pp 72-73: “... shortly after the beginning of World War II, European investors and governments attempted to sell shares in American corporations in New York, so as to raise funds for their war efforts. They quickly found that N.Y.S.E. specialists, who had become overly cautious due to the depression, were unable to execute sales of 10,000 or so shares of U.S. Steel, Standard Oil of New Jersey, or General Motors, or if they could, wanted to do so at prices that were several points below the last recorded trade."

182 Ibid., p 54.

183 Ibid., pp 72-73.

184 Hardy CO (1939/1975) p 1: “On all of the important American stock exchanges the standard method of trading is through oral bids and offers made on the floor of the exchange, for blocks of stock of a specific size, which are known as 'round lots.' Orders for smaller quantities and less than round-lot remainders of larger orders, which are known as 'odd lots,' are not matched against one another in the auction markets, but are turned over to dealers who stand ready at all times to buy and sell at prices which are fixed automatically by the current round-lot price."

185 Ibid., p 10. For the principles of the odd-lot dealer system, see pp 129-130.

186 Ibid., p 132: "It would be possible to organize, alongside the round-lot market, a secondary auction market with a 1-share unit of trading in which bids and offers in odd lots would be matched directly against one other ... Undoubtedly, therefore, therefore, the commission rates per share would have to be considerably higher than they are at present. In the writer's opinion, considerations of cost are decisive against any such plan."

187 Ibid., p 132. 
Much more fundamental changes took place after the turn of the millennium. Stock markets were changed by Regulation NMS. The SEC has described changes in the nature of trading for NYSE-listed stocks as "extraordinary". In January 2005, the NYSE executed approximately $79.1 \%$ of the consolidated share volume in its listed stocks. In October 2009, the figure was down to $25.1 \%$. The change was facilitated by regulation and technological advancement and attributable to the rise of alternative venues. ${ }^{188}$ Moreover, the NMS rules concerning automated access necessitated by Rule 611 were "the death knell for the specialist system on the NYSE". ${ }^{189}$

The history of the NYSE shows that alternative venues are part of the evolution of stock exchanges. The rise of various kinds of alternative venues for trade execution has changed the nature of stock exchanges.

One can distinguish between different kinds of alternative venues of trade execution on the basis of how they work (their function, section 3.3.2) or regulation (their legal classification in the EU, section 3.3.3, and the US, section 3.3.4). While the efficiency of price discovery can be reduced by the mere existence of many alternative venues, the business model of alternative venues that are dark pools is based on reducing the transparency of price discovery for most traders. The regulation of broker-dealer order internalisation and the limits of unregulated OTC markets play a key role in the development of alternative venues in the EU and US (section 3.4). SME exchanges have been used as a tool to address the shortage of companies with publicly-traded shares (section 3.5).

\subsubsection{The Function of Alternative Venues}

Alternative systems can work in different ways and have different functions. Obviously, if alternative venues are defined as the alternative to stock exchanges, the definition is very broad indeed - virtually unlimited - and can cover many kinds of systems. ${ }^{190}$

188 SEC Release No. 34-61358 (Jan. 14, 2010) (Concept Release on Equity Market Structure), section I.

189 Fox MB, Glosten LR, Greene EF, Patel MS (2018) pp 23-24.

190 FESCO (2000) paragraph 11: "The experts group has agreed that, for the purpose of this paper, the following definition of ATS should be used: 'An ATS is an entity which, without being regulated as an exchange, operates an automated system that brings together buying and selling interests - in the system and according to rules set by the system's operator - in a way that forms, or results in, an irrevocable contract.”” 
The oldest major alternative is over-the-counter (OTC) trading. OTC contracts are nowadays defined as privately negotiated contracts that are not executed on a regulated exchange. ${ }^{191}$

There is a large variety of alternative venues. One can generally distinguish between alternative venues on the basis of: whether the operator focuses on technology or rule-making; the nature of services in general; the principles of the matching of bids; and whether orders are internalised or not.

First, the operator of an alternative system can focus on technology or the system's rules. ${ }^{192}$ After the turn of the millennium, Baum distinguished between the following kinds of electronic facilities that are alternative systems: ${ }^{193}$ passive electronic bulletin boards; ${ }^{194}$ active electronic bulletin boards; ${ }^{195}$ order-routing systems; ${ }^{196}$ day-trading centers; ${ }^{197}$ crossing systems; ${ }^{198}$ proprietary trading systems; or electronic communication networks. When the operator of an alternative system makes rules, the operator regulates the characteristic services of the system.

Second, an alternative system can be limited to just some of the typical exchange services. ${ }^{199}$ One can distinguish between pre-trading activities, trading

191 See, for example, recital 4 and point 7 of Article 2 of Regulation 648/2012 (EMIR).

192 Recital 6 of Directive 2004/39/EC (MiFID).

193 Baum H (2002) p 106.

194 Only offers are posted; trading takes place between the parties and the system is not involved. See, for example Article 25 of Regulation (EU) 2020/1503 (ELSP Regulation).

195 The system matches offers, acting as an agent for one party.

196 Orders are collected and passed for profit to a specific trading platform. SEC (2000) Part II, I.B footnote 10: "These order-routing systems may be operated by, or on behalf of, an OTC market maker or exchange market maker that executes customer orders primarily against the account of such market maker as principal, other than riskless principal.”

197 Rooms and computer terminals linked to exchange members are provided for trading by private investors.

198 SEC (2000) Part II, I.B: “The definition [of ECN] specifically excludes internal broker-dealer ... crossing systems - i.e., systems that cross multiple orders at a single price set by the ECN and that do not allow orders to be crossed or executed against directly by participants outside of the specified times."

199 Mues J (1999) pp 29-30; Baum H (2002) p 106: “Typical exchange services are: dissemination of pre-trade information, order routing, price determination, matching and confirmation, reporting and documentation, dissemination of post-trade information, clearing and settlement ...” Macey JR, Kanda H (1990) pp 1009-1010: "We show that the product offered by organized securities exchanges, which is called a 'listing,' can be unbundled into four component parts. Specifically, organized exchanges provide listing companies with: (1) liquidity, (2) monitoring of exchange trading, (3) standard form, off-the-rack rules to reduce transactions costs, and (4) a signalling function that serves to inform investors that the issuing companies' stock is of high quality." 
activities, and post-trading activities. Moreover, the services can include clearing and central counterparty services as well as settlement and custody functions. ${ }^{200}$ Consequently, these services can include: dissemination of pre-trade information and post-trade information; ${ }^{201}$ bringing together parties that want to participate in trading; ${ }^{202}$ price discovery; ${ }^{203}$ matching of bids (order routing, price determination, matching, confirmation); acting as central counterparty; ${ }^{204}$ reporting and documentation; ${ }^{205}$ and clearing and settlement. ${ }^{206}$ Like stock exchanges, an alternative system can provide signalling services for issuers. ${ }^{207}$

Third, one can distinguish between different kinds of alternative systems on the basis of the principles of the matching of bids. Buying and selling interests (such as orders, quotes, and indications of interest) can be brought together in the system by means of non-discretionary rules set by the system operator (such as the system's rules, the system's protocols, internal operating procedures, and procedures embodied in computer software). ${ }^{208}$ Depending on the rules, one can thus distinguish between: quote-driven systems; order-driven systems (subdivided into continuous matching and auction matching systems);

200 See, for example, European Code of Conduct for Clearing and Settlement of 7 November 2006.

201 See, for example, recital 53 and Article 65 of Directive 2014/65/EU (MiFID II).

202 See, for example, Article 4(1) of Directive 2014/65/EU: "For the purposes of this Directive, the following definitions apply: ... (19) 'multilateral system' means any system or facility in which multiple third-party buying and selling trading interests in financial instruments are able to interact in the system; ...”

203 Baum H (2002) pp 105-107 on alternative trading systems (ATS): "As a rule, the securities traded here are principally traded on securities exchanges or other organized markets. Some ATSs have price discovery functions; other serve as matching systems using only prices already established on organized markets."

204 See, for example, Article 2 of Regulation 648/2012 (EMIR): "For the purposes of this Regulation, the following definitions shall apply: (1) 'CCP' means a legal person that interposes itself between the counterparties to the contracts traded on one or more financial markets, becoming the buyer to every seller and the seller to every buyer; ...”

205 Ibid.: "For the purposes of this Regulation, the following definitions shall apply: ... (2) 'trade repository' means a legal person that centrally collects and maintains the records of derivatives; ...”

206 Ibid.: "For the purposes of this Regulation, the following definitions shall apply: ... (3) 'clearing' means the process of establishing positions, including the calculation of net obligations, and ensuring that financial instruments, cash, or both, are available to secure the exposures arising from those positions; ...”

207 For signalling services, see Macey JR, Kanda H (1990) pp 1023-1024.

208 See, for example, recital 6 of Directive 2004/39/EC (MiFID). 
price-taking systems (crossing systems); and active bulletin boards. ${ }^{209}$ FESCO described their basic principles of matching as follows: ${ }^{210}$

- Quote-driven systems: "Display of dealer quotes. Automatic execution against quotes."

- Order-driven systems, continuous matching: "Public limit order book. Market and limit orders continously matched in time and price priority."

- Order-driven systems, auction matching: "Limit orders and 'at the opening' orders stored in a batch. Algorithm calculates a single price at a set time to maximize execution."211

- Price-taking (crossing) systems: "File of market orders (possibly with min/ max execution limits). System crosses orders at single benchmark prices."

- Active Bulletin Boards: "Display of invitations to offer. System declares acceptance of offers."

Fourth, buying and selling interests can be matched on a discretionary basis. An alternative system could be a broker-dealer acting as a market participant in the OTC market or a broker-dealer acting as a market by internalising customer order flows. ${ }^{212}$ Over-the-counter (OTC) contracts traditionally have been defined as privately negotiated contracts in the sense that their execution does not take place on a regulated exchange. ${ }^{213}$ Broker-dealers traditionally have chosen to internalise orders to avoid regulated exchanges. A broker-dealer can act as a systematic internaliser or operate a dark pool (see sections 3.3.3 and 3.4). ${ }^{214}$

209 FESCO (2000) paragraph 14.

210 Ibid., paragraph 15.

211 See also Schwartz RA (2000): "How do orders meet in time? In a quote driven market, a market maker solves the time problem by selling to the buyer at 10:50 and buying from the seller at 10:55. In an order driven market, the limit order placed by one participant enables another participant at another moment in time to trade with immediacy by market order. A third alternative is the call auction. The call enables a large number of buyers and sellers to meet because it establishes a predetermined meeting point in time."

212 SEC (2000) Part II, I.C: "In short, Regulation ATS recognized the evolving role that alternative trading systems play in our securities markets. It gave these systems the choice of registering with the Commission either as an exchange or as a broker-dealer. The option they chose - registering as a market participant, or as a market - affected their rights and responsibilities. Regulation ATS provided alternative trading systems with a regulatory structure which incorporated them into the national market system, while preserving their flexibility."

213 See, for example, recital 4 and point 7 of Article 2 of Regulation 648/2012 (EMIR).

214 See, for example, recital 17 of Directive 2014/65/EU (MiFID II): "Systematic internalisers should be defined as investment firms which, on an organised, frequent, systematic and substantial basis, deal on own account when executing client orders outside a regulated market, an MTF or an OTF. In order to ensure the objective and effective application of that definition 
There seems to be a wide range of alternative venues reflecting technological advancement, financial and business innovation, and the evolution of market practices.

\subsubsection{The Regulation of Alternative Venues in the EU}

A key issue when distinguishing between traditional exchanges and alternative venues is regulation. Alternative venues do not exist if they are subject to the same regulatory framework as traditional exchanges. Alternative venues cannot provide an alternative unless they are regulated in a different way.

The distinction between traditional regulated exchanges and alternative venues has become blurred. The trend is that alternative venues do not escape the scope of financial markets regulation where they are functional equivalents to traditional regulated exchanges. The functional characteristics of the system connecting buying and selling interests have become more important over time. ${ }^{215}$

For example, OTC markets would not really be a functional equivalent to traditional stock exchanges in Europe. There are no efficient secondary markets without standardised instruments and highly organised trading. The trend is that marketplaces for trading in standardised contracts must fall within the scope of the regulatory regime for financial markets regardless of whether the contracts are regarded as OTC contracts or the marketplace is regulated as an exchange. Generally, OTC trading has played a rather limited role on European equity markets. ${ }^{216}$

We can have a look at three EU directives that have had a great impact on alternative exchanges in Europe, namely the Investment Services Directive (ISD), ${ }^{217}$ MiFID, ${ }^{218}$ and MiFID II. ${ }^{219}$

to investment firms, any bilateral trading carried out with clients should be relevant and criteria should be developed for the identification of investment firms required to register as systematic internalisers. While trading venues are facilities in which multiple third party buying and selling interests interact in the system, a systematic internaliser should not be allowed to bring together third party buying and selling interests in functionally the same way as a trading venue."

215 See, for example, recital 6 of Directive 2004/39/EC (MiFID): "Definitions of regulated market and MTF should be introduced and closely aligned with each other to reflect the fact that they represent the same organised trading functionality ...”

216 Fioravanti SF, Gentile M (2011) p 9.

217 Council Directive 93/22/EEC of 10 May 1993 on investment services in the securities field. 218 Directive 2004/39/EC of the European Parliament and of the Council of 21 April 2004 on markets in financial instruments amending Council Directives 85/611/EEC and 93/6/EEC and Di- 
Investment Services Directive. When the ISD was adopted in 1993, exchanges enjoyed a national franchise for the organised matching of buy/sell interests in locally issued securities. 220

The ISD introduced the principles of a single authorisation valid throughout the Community (one-stop shop) ${ }^{221}$ and home-country control ${ }^{222}$ for financial services in the European Community. It focused on access to regulated markets and transactions carried out on regulated markets. "Regulated markets" were defined as particular named markets that were regulated by the competent authorities. ${ }^{223}$ Generally, the ISD increased cross-border competition between financial intermediaries and between exchanges. ${ }^{224}$

Increased cross-border competition and the right to have transactions carried out away from a regulated market ${ }^{225}$ could have left plenty of room for alternative venues to emerge. In 2000, FESCO defined an alternative trading system as "an entity which, without being regulated as an exchange, operates an automated system that brings together buying and selling interests - in the system and according to rules set by the system's operator - in a way that forms, or results in, an irrevocable contract”. ${ }^{226}$ The definition was broad enough to capture "any trading functionality regardless of whether that functionality operates bilat-

rective 2000/12/EC of the European Parliament and of the Council and repealing Council Directive 93/22/EEC. MiFID came into force in 2007.

219 Directive 2014/65/EU of the European Parliament and of the Council of 15 May 2014 on markets in financial instruments and amending Directive 2002/92/EC and Directive 2011/61/EU.

220 Proposal for a Directive of the European Parliament and of the Council on investment services and regulated markets, COM/2002/0625 final, section II.1.

221 See, for example, Articles 14(2) and 15(1) of Directive 93/22/EEC (ISD).

222 Article 3(1) of Directive 93/22/EEC (ISD).

223 Article 1 of Directive 93/22/EEC (ISD): "For the purposes of this Directive: ... 13. regulated market shall mean a market for the instruments listed in Section B of the Annex which:

- appears on the list provided for in Article 16 drawn up by the Member State which is the home Member State as defined in Article 1 (6) (c),

- functions regularly,

- is characterized by the fact that regulations issued or approved by the competent authorities define the conditions for the operation of the market, the conditions for access to the market and, where Directive 79/279/EEC is applicable, the conditions governing admission to listing imposed in that Directive and, where that Directive is not applicable, the conditions that must be satisfied by a financial instrument before it can effectively be dealt in on the market,

- requires compliance with all the reporting and transparency requirements laid down pursuant to Articles 20 and 21; ...“

224 See, for example, Demarchi M, Foucault T (2000).

225 Article 14(4) of Directive 93/22/EEC (ISD).

226 FESCO (2000) paragraph 11. See also Baum H (2002) pp 105-107. 
erally or multilaterally". It included "not only ATSs which contribute to the price discovery process through the matching of priced orders and the lifting of quotes", but even "crossing mechanisms which match buying and selling interests at a ('reference') price determined elsewhere, e.g. on an exchange”. ${ }^{227}$

However, the ISD created "a formidable stumbling-block to the emergence of an integrated and competitive trading infrastructure" by only providing for an optional approach to the regulation of market structure. The "concentration rule" allowed national authorities to limit the execution of retail investor orders to "regulated markets". ${ }^{228}$ Most venue-based equity trading in Europe was already conducted on large national exchanges that acted as near-monopolies in each country. ${ }^{229}$ The concentration rule thus contributed to concentration along national borders and increased the cost of cross-border transactions. ${ }^{230}$ Moreover, the existence of the concentration rule as an option resulted in "greater diversity of order-execution methodologies" in the countries that elected not to use the option and gave rise to "discrepancies between national trading conventions". ${ }^{231}$

After the adoption of the ISD, European markets got a more complex structure. The boundary between marketplaces and intermediaries became blurred. There were non-exchange marketplaces, and exchanges had turned into competitive market players. ${ }^{232}$ Exchanges could not be regarded as natural monopolies any more. ${ }^{233}$

MiFID. The ISD was replaced by Directive 2004/39/EC on markets in financial instruments (MiFID) that came into force in 2007. The main objectives of MiFID were to allow investment firms to provide cross-border services and to ensure a high level of investor protection. ${ }^{234}$ According to the European Commission, a key objective of MiFID was "to ensure robust competition on a level playingfield between trading platforms". ${ }^{235}$ MiFID introduced a new market structure

227 FESCO (2000) paragraph 12. See also Baum H (2002) pp 105-107.

228 Article 14(3) of Directive 93/22/EEC (ISD).

229 Petrescu M, Wedow M (2017) p 12.

230 Fioravanti SF, Gentile M (2011) p 6 footnote 1.

231 Proposal for a Directive of the European Parliament and of the Council on investment services and regulated markets, COM/2002/0625 final, section I.3.

232 Ibid., section II.1.

233 Baum H (2004) pp 680-681.

234 Recital 2 of Directive 2004/39/EC (MiFID).

235 European Commission, Review of the Markets in Financial Instruments Directive (MiFID): Frequently Asked Questions. MEMO/11/716, 20 October 2011. 
framework and increased the volume of trading outside primary stock exchanges. ${ }^{236}$

First, MiFID eliminated the concentration rule. Primary exchanges could now face competition from other venues across all Member States.

Second, MiFID sought to establish a comprehensive regulatory regime for trading in equity instruments in the EU irrespective of the trading method or platform. It regulated the main types of exchanges in the European financial market and was not limited to venues of primary listing (national stock exchanges). A new category of multilateral trading facilities (MTFs) was introduced to encompass all other organised multi-party trading facilities with non-discretionary execution that were not already registered as regulated markets. ${ }^{237}$

Third, MiFID sought to harmonise pre- and post-trade transparency requirements for equity trading on all regulated platforms.

MiFID thus made the earlier distinction between regulated markets and markets that were not regulated outdated. MiFID was designed to cover "the main types of order-execution arrangement" then in use in the European financial marketplace and to "establish a comprehensive regulatory regime". New organised trading systems were made subject to the same regulatory regime as the earlier regulated markets. ${ }^{238}$ In other words, MiFID had ambitious goals. ${ }^{239}$

Regulated markets were defined in a more functional way. The notion of regulated markets was complemented by the notion of MTFs. Both represented "the same organised trading functionality" and excluded bilateral systems "in which an investment firm enters into every trade on own account and not as a riskless counterparty interposed between the buyer and seller". ${ }^{440}$

236 Fioravanti SF, Gentile M (2011) p 5.

237 Petrescu M, Wedow M (2017) pp 12-13. See even judgment of 16 November 2017, Robeco Hollands Bezit and Others NV v Stichting Autoriteit Financiële Markten (AFM), C-658/15, ECLI: EU:C:2017:870, paragraph 26.

238 Recital 5 of Directive 2004/39/EC (MiFID).

239 See, for example, Robeco, C-658/15, ECLI:EU:C:2017:870, paragraph 43: “... As the Commission states in its written observations, the provisions of Directive 2004/39 concerning regulated markets are not intended merely to prevent abuse. As follows, inter alia, from recitals 2 and 5 of that directive, those provisions aim, more broadly, at the harmonisation needed to offer investors a high level of protection, by establishing a comprehensive regulatory regime governing the execution of transactions in respect of financial instruments so as to ensure a high quality of execution of transactions and to uphold the integrity and overall efficiency of the financial system."

240 Ibid., paragraphs $30-31$. 
What was characteristic of "regulated markets" and "MTFs" was the existence of a set of rules. In other words, both definitions were technology neutral. Technology neutrality was reflected in the recitals of MiFID:

“The term 'system' encompasses all those markets that are composed of a set of rules and a trading platform as well as those that only function on the basis of a set of rules. Regulated markets and MTFs are not obliged to operate a 'technical' system for matching orders. A market which is only composed of a set of rules that governs aspects related to membership, admission of instruments to trading, trading between members, reporting and, where applicable, transparency obligations is a regulated market or an MTF within the meaning of this Directive and the transactions concluded under those rules are considered to be concluded under the systems of a regulated market or an MTF. The term 'buying and selling interests' is to be understood in a broad sense and includes orders, quotes and indications of interest. The requirement that the interests be brought together in the system by means of non-discretionary rules set by the system operator means that they are brought together under the system's rules or by means of the system's protocols or internal operating procedures (including procedures embodied in computer software). The term 'non-discretionary rules' means that these rules leave the investment firm operating an MTF with no discretion as to how interests may interact. The definitions require that interests be brought together in such a way as to result in a contract, meaning that execution takes place under the system's rules or by means of the system's protocols or internal operating procedures."241

The new category of MTFs gained market share. The share of equities trading on MTFs in Europe increased from 0\% of turnover in 2008 to 18\% by early 2011 and accounted for around $40 \%$ of equity trading volumes in $2017^{242}$ While each regulated market traditionally specialised in the stocks of its home country, MTFs diverted order flow from regulated markets by offering trading in the most liquid EU equities on technologically advanced trading platforms, and lower fees. ${ }^{243}$ The elimination of the use of the concentration rule reduced the costs of entry for new venues, as they could compete for volumes across a broader set of instruments from a larger number of countries. ${ }^{244}$ This provided "greater opportunities for pan-European trading”. ${ }^{245}$

241 Recital 6 of Directive 2004/39/EC (MiFID).

242 Fioravanti SF, Gentile M (2011) pp 5 and 8; Petrescu M, Wedow M (2017) pp 12-13.

243 Fioravanti SF, Gentile M (2011) p 10 and footnote 13.

244 Petrescu M, Wedow M (2017) p 12. 
The broader scope of pre- and post-trading transparency requirements contributed to the growth of dark pools. ${ }^{246}$ MiFID did not apply to dark pools. ${ }^{247}$ The emergence of dark pools was an answer to demand by market participants that wished to continue trading "in the dark". ${ }^{448}$

Having said this, the impact of MiFID on the European market seems to have been less significant than the impact of Regulation NMS on the US market. ${ }^{249}$ This was mainly due to discrepancies in the ways in which Regulation NMS and MiFID regulated data consolidation and best execution. Regulation NMS created a consolidated market data system and focused more on price. ${ }^{250}$ The problems were ultimately recognised by the European Commission..$^{251}$

MiFID II. The scope of the regulatory regime was expanded by MiFID II that replaced MiFID. MiFID II applies to "investment firms", "market operators", and "multilateral systems", among other things. ${ }^{252}$ The respective definitions of these notions have a major effect on the scope of the regime.

According to MiFID II, the operation of a "multilateral system" is a regulated activity. A "multilateral system" means "any system or facility in which multiple third-party buying and selling trading interests in financial instruments are able to interact in the system". ${ }^{253}$ There are different kinds of trading venues depending on the characteristics of the multilateral system. For the trading of shares, a multilateral trading system can be a "regulated market" 254 or a "multilateral trading facility”255 (MTF) but not an "organised trading facility” (OTF). ${ }^{256}$ For exam-

245 European Commission (2010) p 5. See also paragraph 70 of Commission Decision of 29 March 2017 declaring a concentration to be incompatible with the internal market and the functioning of the EEA Agreement (Case M.7995- Deutsche Börse / London Stock Exchange). 246 Fioravanti SF, Gentile M (2011) pp 5 and 8; Petrescu M, Wedow M (2017) pp 12-13.

247 See Boskovic T, Cerruti C, Noel M (2010).

248 Petrescu M, Wedow M (2017) pp 11-12.

249 Fioravanti SF, Gentile M (2011) p 5.

250 Ibid., pp 5 and 7 on MiFID and p 12 on Regulation NMS. See recital 33 and Article 21(1) of Directive 2004/39/EC (MiFID).

251 European Commission (2010) pp 30-31: “The suggestions of the Commission services in this area can be grouped under a number of different headings: a) Improving the quality and consistency of raw trade data and ensuring it is provided in a consistent format (to facilitate consolidation); b) Reducing the cost of post-trade data for investors; and c) Introducing a consolidated tape for the EU market.” See also Fioravanti SF, Gentile M (2011) pp 7-8.

252 Article 1(1) of Directive 2014/65/EU (MiFID II).

253 Point (19) of Article 4(1) of Directive 2014/65/EU (MiFID II).

254 Point (21) of Article 4(1) of Directive 2014/65/EU (MiFID II).

255 Point (22) of Article 4(1) of Directive 2014/65/EU (MiFID II).

256 Point (23) of Article 4(1) of Directive 2014/65/EU (MiFID II). 
ple, SME growth markets, growth markets, and junior markets are sub-categories of MTFs. ${ }^{257}$

The "market operators" that fall within the scope of MiFID II are persons that manage or operate the business of a "regulated market". ${ }^{258}$ A person that operates an MTF (or an OTF) falls within the scope of MiFID II as an "investment firm" 259 but can even be a "market operator". ${ }^{260}$ Each of these activities requires an authorisation. ${ }^{261}$ All of these venues or their operators are subject to regulatory compliance obligations. ${ }^{262}$

The "market operator" of an MTF can be a "central counterparty" (CCP). A CCP is defined as "a legal person that interposes itself between the parties to the contracts traded on one or more financial markets, becoming the buyer to every seller and the seller to every buyer". ${ }^{263}$ However, a CCP is not a multilateral system as such, and there is a distinction between (a) acting as a CCP (and clearing house) ${ }^{264}$ for a multilateral system on one hand and (b) operating a multilateral system on the other.

The definition of "investment firm" is a broad one. It means "any legal person whose regular occupation or business is the provision of one or more investment services to third parties and/or the performance of one or more investment activities on a professional basis". ${ }^{265}$ Such investment services include, among things, "dealing on own account", "reception and transmission of orders in relation to one or more financial instruments", and "execution of orders on behalf of clients". ${ }^{266}$

MiFID II gives several examples of persons that fall within the scope of the directive by "dealing on own account" in shares.

First, they include persons that are "market makers". A market maker is "a person who holds himself out on the financial markets on a continuous basis as

257 Recital 132 and point 23 of Article 4(1) of Directive 2014/65/EU (MiFID II).

258 Point (18) of Article 4(1) of Directive 2014/65/EU (MiFID II).

259 Points (8) and (9) of Section A of Annex I to Directive 2014/65/EU (MiFID II).

260 Points 22 and 23 of Article 4(1) of Directive 2014/65/EU (MiFID II).

261 Articles 5(1) and 44(1) of Directive 2014/65/EU (MiFID II).

262 Articles 18(1), 31(1) and 44(1) of Directive 2014/65/EU (MiFID II).

263 Recital 15 and point (51) of Article 4(1) of Directive 2014/65/EU (MiFID II); point (1) of Article 2 of Regulation 648/2012 (EMIR).

264 Article 2 of Regulation 648/2012 (EMIR): "For the purposes of this Regulation, the following definitions shall apply: ... (3) 'clearing' means the process of establishing positions, including the calculation of net obligations, and ensuring that financial instruments, cash, or both, are available to secure the exposures arising from those positions; ...”

265 Point (1) of Article 4(1) of Directive 2014/65/EU (MiFID II).

266 Section A of Annex I to Directive 2014/65/EU (MiFID II). 
being willing to deal on own account by buying and selling financial instruments against that person's proprietary capital at prices defined by that person". ${ }^{267}$

Second, persons that fall within the scope of MiFID II by "dealing on own account" in shares include persons that "deal on own account when executing client orders". ${ }^{268}$ A sub-category of this group is "systematic internalisers". They have been defined in MiFID II as investment firms which, on an organised, frequent, systematic and substantial basis, deal on own account by executing client orders - outside regulated trading venues and without operating a multilateral system. ${ }^{269}$

Systematic internalisers must not become the functional equivalents of “multilateral systems”. According to a Commission Delegated Regulation, “[a] systematic internaliser should not be allowed to bring together third party buying and selling interests in functionally the same way as a trading venue. A systematic internaliser should not consist of an internal matching system which executes client orders on a multilateral basis, an activity which requires authorisation as a multilateral trading facility (MTF). An internal matching system in this context is a system for matching client orders which results in the investment firm undertaking matched principal transactions on a regular and not occasional basis."270

Third, examples of persons that fall within the scope of MiFID II by "dealing on own account" in shares include persons that "are members of or participants in a regulated market or an MTF or have direct electronic access to a trading venue" or "apply a high-frequency algorithmic trading technique". ${ }^{271}$

Generally, electronic markets seem to have adapted to new EU regulations in the same way they did to Dodd-Frank in the US. Overall market volumes are up. ${ }^{272}$

Conclusion. In the EU, the main design principle applicable to alternative venues is that they should fall within the scope of the regulatory regime for traditional exchanges when they are functional equivalents to multilateral systems.

267 Point (7) of Article 4(1) of Directive 2014/65/EU (MiFID II).

268 Points (2) and (3) of Section A of Annex I to Directive 2014/65/EU (MiFID II); point (d) of Article 2(1) of Directive 2014/65/EU (MiFID II).

269 Recital 17 and point 20 of Article 4(1) of Directive 2014/65/EU (MiFID II).

270 Recital 19 of Regulation (EU) 2017/565. See also Article 12 of Regulation (EU) 2017/565 on the definition of a systematic internaliser.

271 Article 2(1) of Directive 2014/65/EU (MiFID II).

272 Lee Olesky, Opinion Mifid: How the market has adapted to Mifid II. Financial Times, $10 \mathrm{Au}$ gust 2018. 
An internal matching system that executes client orders on a multilateral basis falls within the regulatory regime for traditional exchanges as an MTF. The regulatory regime therefore has grown hand in hand with the evolution of alternative trading mechanisms. The interests of issuer-firms have not belonged to the drivers of legislative change.

\subsubsection{The Regulation of Alternative Venues in the US}

The regulation of alternative venues has reduced small-company IPOs in the US. In the US, the Securities and Exchange Commission (SEC) has distinguished between four kinds of trading centers (or markets): registered exchanges, Electronic Communications Networks (ECNs), dark pools, and broker-dealer internalisation. ${ }^{273}$ Registered exchanges have to register with the SEC and meet the regulatory requirements. ECNs and dark pools are regarded as "alternative trading systems" (ATS) that trade listed stocks and other exchange-traded products. Therefore, the three principal types of trading venues are stock exchanges, alternative trading systems, and non-ATS off-exchange trade, which is mostly internalisation. ${ }^{274}$

The term ECN was coined by the SEC in $1998 .^{275}$ It describes a particular way to bring together buying and selling interests. The SEC has defined an ECN "as any electronic system that widely disseminates to third parties orders entered into it by an exchange market maker or over-the-counter ('OTC') market maker, and permits such orders to be executed in whole or in part."276 The term ECN thus refers to "order-driven systems where the buy and sell orders of investors meet directly in an order book, either in a call auction or in continuous trading. To conduct trades on ECNs, subscribers (institutional investors, broker-dealers, and market makers) place trades directly with an ECN. Individual investors must have an account with a broker-dealer subscriber in order to place trades on an ECN." "277 As alternative trading systems (ATSs), ECNs are required to register

273 SEC Release No. 34-61358 (Jan. 14, 2010) (Concept Release on Equity Market Structure), section III.

274 Fox MB, Glosten LR, Rauterberg GV (2019) p 15.

275 SEC Rule 6954(c); SEC Release No. 34-39729 (March 6, 1998). See even Baum H (2002) pp 105-107: "What are an ECN and/or an ATS? No generally accepted definitions exist. Put simply, an ECN brings together buyers and sellers for an electronic execution of trades."

27617 CFR §240.11Ac1-1(a)(8). See SEC (2000) Part II, I.B.

277 Christiansen H, Koldertsova A (2009) p 228, Box III.3.1. 
with the SEC as broker-dealers. The SEC publishes a list of ATSs including all ECNs.

Where a broker-dealer prefers not to act as a market by internalising customer order flows, it can act as a market participant in the OTC market. ${ }^{278}$ The SEC's definition of an ECN excludes internal broker-dealer order-routing systems and crossing systems. ${ }^{279}$

The 1975 Amendments. In the early 1970s, Congress was concerned about trading fragmentation and poor customer executions. Congress believed that they resulted from the trading of securities in separate, unconnected markets. Congress directed the SEC to facilitate the development of a national market system for securities as part of the Securities Acts Amendments of 1975 (see section 4.2.4). ${ }^{280}$ An essential means to achieve a national market system was "to make information on prices, volume, and quotes for securities in all markets available to all investors, so that buyers and sellers of securities, wherever located, can make informed investment decisions and not pay more than the lowest price at which someone is willing to sell, or not sell for less than the highest price a buyer is prepared to offer." ${ }^{281}$ According to the SEC, these findings and objectives have guided it as it has "sought to keep market structure rules upto-date with continually changing economic conditions and technology advances”. 282

However, the assumption that one market will best serve the needs of all investors did not capture the realities of markets. Investors have different needs inter se, and various kinds of other market participants have needs as well. Different and fragmented markets developed to serve them as a result of competition. $^{283}$

When ECNs emerged, ${ }^{284}$ they were not integrated into the national market system. Their growth created a two-tiered market, that is, the traditional public

278 SEC (2000) Part II, I.C: "In short, Regulation ATS recognized the evolving role that alternative trading systems play in our securities markets. It gave these systems the choice of registering with the Commission either as an exchange or as a broker-dealer. The option they chose - registering as a market participant, or as a market - affected their rights and responsibilities.” 279 SEC (2000) Part II, I.B and footnote 10.

280 Section 7 of the Securities Acts Amendments of 1975.

281 See SEC (2000) Part II, II.A, footnote 17 quoting SEC, Statement of the Securities and Exchange Commission on the Future Structure of the Securities Markets (February 2, 1972), 37 FR 5286 (February 4, 1972).

282 SEC Release No. 34-61358 (Jan. 14, 2010) (Concept Release on Equity Market Structure), section II.

283 Blume ME (2000).

284 See Christiansen H, Koldertsova A (2009) pp 227-229. 
market. The use of ECNs enabled market makers to maintain artificially wide quotes in the public market. The new ECN market with limited access had better prices. $^{285}$

Order Handling Rules. In 1996, the SEC Commission adopted the Order Handling Rules ${ }^{286}$ to address the two-tiered market. Market makers and specialists were now required to reflect in their quote the price of any orders they placed in an ECN if the price was better than their own public quotation. This helped to narrow the spreads between bids and offers and bring ECNs into the national market system.

However, the Order Handling Rules neither said how ECNs should be regulated in the markets nor required all market participants to report to the public quotation stream the orders they placed in ECNs. It turned out that the regulation of broker-dealers was not adequate. ${ }^{287}$

Regulation ATS. In 1998, the SEC adopted Regulation ATS. ${ }^{288}$ Regulation ATS laid down a comprehensive framework that allowed alternative trading systems to choose whether to register as an exchange or to be licensed as a broker-dealer subject to certain additional requirements. ${ }^{289}$ An important element in the introduction of Regulation ATS was the SEC's wish to level the playing field. In addition to increasing the regulation of certain alternative trading systems, it relaxed certain regulatory requirements for exchanges to enable them to compete more effectively. An important relaxation was the removal of the requirement that an exchange should be a mutual organisation, thus paving the way for exchanges to demutualise and become for-profit organisations. ${ }^{290}$

Both the registered exchanges and their alternatives are run by trading systems that automatically receive, process, and execute orders.

After the adoption of Regulation ATS, an ECN could register either as an exchange ${ }^{291}$ or as a broker-dealer. ${ }^{292}$ In the latter case, it had a duty to comply with

285 SEC (2000) Part II, II.A.

286 Exchange Act Release No. 37619 A (Order Handling Rules Release).

287 SEC (2000) Part II, II.B; FESCO (2000) paragraph 26.

288 SEC Release No. 34-40760 (Regulation of Exchanges and Alternative Trading Systems, "Regulation ATS").

289 See FESCO (2000) paragraph 27; SEC (2000) Part II, II.C.

290 FESCO (2000) paragraph 28.

291 Section 6 of the Securities Exchange Act.

292 Section 15 of the Securities Exchange Act. 
requirements under Regulation ATS. ${ }^{293}$ The choice influenced costs and access to broker-dealers. ${ }^{294}$

First, registration as a broker-dealer eliminated the statutory and costly obligation to become a self-regulatory organisation.

Second, registered exchanges were required to offer broad access to brokerdealers. Broker-dealers that internalised trades were not subject to fair access requirements. An alternative trading system that was exempt from exchange registration was not required to provide fair access unless it reached a 5\% trading volume threshold in a stock. Access to the undisplayed liquidity of dark pools and broker-dealers was determined primarily by private negotiation. ${ }^{295}$

This influenced the business model of exchanges and ECNs: "ECNs started executing and reporting trades through particular exchanges and sharing in data revenues."296 To combine the regulatory status of the exchange with the trading platforms of ECNs, exchanges and ECNs formed alliances: "The ECN benefited as it did not have to build regulatory costs into its business model and the exchange benefited from the transaction and market data fee revenues generated by the ATSs."297

Regulation NMS. In 2005, the SEC adopted Regulation NMS. ${ }^{298}$ Regulation NMS has been described as an example of interventionist regulatory choices. ${ }^{299}$

The stated objectives of Regulation NMS were to promote "competition among markets and competition among individual orders", 300 and to "minimize the transaction costs of long-term investors and thereby to reduce the cost of capital for listed companies". ${ }^{301}$ Its main tools consisted of four kinds of rules: the "Order Protection Rule", the "Access Rule”, the "Sub-Penny Rule”, and amendments to the "Market Data Rules". ${ }^{302}$ Regulation NMS was designed to create a

293 See SEC Release No. 34-61358 (Jan. 14, 2010) (Concept Release on Equity Market Structure), section III.A.3. For the regulatory differences between registered exchanges and ATSs, see section IV.C.3.

294 See ibid., section IV.C.3.

295 See ibid.

296 Aggarwal R, Ferrell A, Katz J (2007).

297 Ibid.

298 Exchange Act Release No. 51808 (June 9, 2005), 70 FR 37496 (June 29, 2005) (Regulation NMS Release).

299 Gadinis S (2008) p 315 on a "surprising choice of regulatory design": "In market structure for equity trading, U.S. regulatory choices are interventionist, and constrain investors' flexibility, while E.U. rules place greater confidence on market forces.”

300 Regulation NMS, I.B.1.

301 Regulation NMS, I.B.2.

302 Regulation NMS, Summary. 
linked national market system and foster competition among the exchanges. This was to be accomplished primarily in two ways. First, Regulation NMS created a consolidated market data system. Second, Regulation NMS implemented the "Order Protection Rule" that requires that any trading venue must execute an order at the current best price in the nation, that is, the National Best Bid and Offer (NBBO). ${ }^{303}$

This influenced market structure as well. ${ }^{304}$ On one hand, Regulation NMS made the business of new trading venues easier and contributed to fragmentation. ${ }^{305}$ On the other, it was even a driver of concentration. Since Regulation NMS confers a regulatory benefit on exchanges that have automated access to the quotations of traditional exchanges, traditional exchanges in the US became more interested in establishing alliances or mergers with ECNs. ${ }^{306}$ Moreover, "exchanges succeeded in [reducing] competition for order flow against other trading venues when they lobbied successfully for the continuation and expansion of the trade-through rules from the organized exchanges to the over-the-counter markets". ${ }^{307}$

Effect on IPOs. It turned out that the Order Handling Rules of 1997 and Regulation ATS of 1998 reduced the number of IPOs. According to an OECD study, they "effectively disintegrated the underlying economic support infrastructure that for decades had fueled the U.S. capital markets". ${ }^{308}$ These two regulatory changes "were the key blows that were the most damaging to the new issue market in the U.S., particularly for small company IPOs". ${ }^{309}$ Intended to reduce trad-

303 Adrian J (2015-2016) pp 260-261.

304 SEC Release No. 34-61358 (Jan. 14, 2010) (Concept Release on Equity Market Structure), section I: "A primary driver and enabler of this transformation of equity trading has been the continual evolution of technologies for generating, routing, and executing orders. These technologies have dramatically improved the speed, capacity, and sophistication of the trading functions that are available to market participants. Changes in market structure also reflect the markets' response to regulatory actions such as Regulation NMS, adopted in 2005, the Order Handling Rules, adopted in 1996, as well as enforcement actions, such as those addressing anti-competitive behavior by market makers in NASDAQ stocks.”

305 Gadinis S (2008) p 323.

306 Aggarwal R, Ferrell A, Katz J (2007).

307 Macey JR, O'Hara M (2005) p 586. For a discussion of the trade-through rule, see Gadinis S (2008) pp 346-352.

308 Weild D, Kim E, Newport L (2013) p 15.

309 Ibid., p 4. 
ing spreads, they hampered market making and contributed to a decline in the number of companies going public. ${ }^{310}$

\subsection{Broker-Dealer Order Internalisation and Dark Pools in EU and US Law}

\subsubsection{General Remarks}

Stock exchanges have long faced competition from off-exchange trading platforms and order internalisation by broker-dealers. Dark trading has existed through over-the-counter (OTC) trading or special hidden order types on exchanges. The most important form of order internalisation is now trading on dark pools. Dark pools are "closed crossing networks which isolate orders from the broad trading and provide participants with liquidity not displayed on open order books". 311

For the purposes of this book, broker-dealer order internalisation and dark pools are interesting for four reasons. First, they indicate that there can be demand for alternative trading mechanisms that fulfil a need. Second, their popularity indicates that maximising "liquidity" may be less important than ensuring a reasonable or acceptable level of liquidity and addressing other objectives. Market participants are heterogeneous and balance different objectives. Third, the regulation of stock exchanges has been adapted to cover even these trading mechanisms. Fourth, the history and regulation of broker-dealer order internalisation and dark pools could help to understand what should be done before part of equity trading could be moved to what we call "microexchanges" (Chapter 8) in the future.

The business of dark pools is made commercially interesting by the intensity of the regulation of exchanges. The regulatory framework gives incentives to move business away from exchanges to dark pools. In the US, dark pools bene-

310 Ibid., pp 15-16 and 4: "Structural and regulatory changes that began with the new Order Handling Rules in 1997 and Regulation Alternative Trading Systems (ATS) in 1998 were the key blows that were the most damaging to the new issue market in the U.S., particularly for small company IPOs. These changes set in motion a dramatic shrinkage in trading spreads and tick sizes in all stocks. While this was, on its face, good news for investors, the ultimate consequences of smaller spreads and tick sizes was manifest in a stark decline in the number of companies going public."

311 Christiansen H, Koldertsova A (2009) p 228, Box III.3.1. See also Shorter G, Miller RS (2014) pp 3-4 on the subgoups of dark pools. 
fited from the adoption of Regulation ATS by the SEC in 1998 and Regulation NMS in $2005 .^{312}$ In the EU, the demand for dark pools increased in part due to regulatory changes regarding pre-trade transparency under MiFID. ${ }^{313}$ The wider scope of pre-trade transparency requirements under MiFID II is expected to increase trading on dark pools. ${ }^{314}$

In the US, the volume of trading on dark pools climbed from about $4 \%$ of overall trading volume in 2008 to about $15 \%$ in $2013 .{ }^{315}$ In the EU, equity trading conducted on dark pools grew from less than $1 \%$ in 2009 to over $8 \%$ in $2016 .^{316}$

In the following, we will have a brief look at the business of dark pools (section 3.4.2) and their regulation in the US and the EU (sections 3.4.3, 3.4.4 and 3.4.6). In practice, the question is whether the activity falls within the scope of the definition of ECN in the US or the definition of multilateral trading facility (MTF) in the EU. We will also have a look at the regulation of broker-dealer internalisation in the US (section 3.4.5) and in the EU (section 3.4.7). The business of dark pools has increased because of algorithmic and high-frequency trading. Both are regulated in the US and the EU (section 3.4.8).

The interests of issuer-firms do not seem to have played any particular role in the regulation of dark pools in the EU and the US.

\subsubsection{The Business of Dark Pools}

The traditional core business of dark pools includes the provision of pre-trade anonymity. Dark pools match buyers and sellers anonymously without public pre-trade information on the best prices. ${ }^{317}$ Institutional investors that trade in large blocks may prefer to trade anonymously. ${ }^{318}$

In the commercial sense, a dark pool is a closed crossing network that isolates orders from the broad trading and facilitates trades that are anonymous rather than displayed on open order books (lit books). Trades in a dark pool are anonymous both in terms of price and identity of participants.

The "textbook" business model of the operator of a dark pool is to "offer trading services to institutional investors and others that seek to execute large

312 Shorter G, Miller RS (2014) pp 1 and 5-6; Kaya O (2016) p 3.

313 Petrescu M, Wedow M (2017) p 4.

314 Ibid., pp 6 and 8.

315 Shorter G, Miller RS (2014) p 4; Aguilar LA (2015); Petrescu M, Wedow M (2017) p 20.

316 Petrescu M, Wedow M (2017) p 5, Chart 1. See also Fioravanti SF, Gentile M (2011) p 9.

317 Kaya O (2016) p 3.

318 Gadinis S (2008) pp 327-328. 
trading interest in a manner that will minimize the movement of prices against the trading interest and thereby reduce trading costs". ${ }^{319}$

The rise of dark pools is connected to the predatory practices of high-frequency traders. There are two views about high-frequency trading (HFT). ${ }^{320}$ While some argue that high-frequency traders improve market quality by lowering bid/ask spreads, reducing volatility, improving short-term price discovery, and creating competitive pressures that reduce broker commissions, ${ }^{321}$ others argue that the predatory practices of high-frequency traders can lead to higher costs of trading for other participants. ${ }^{322}$

Dark pools that operate with waivers from pre-trade transparency can make it more difficult for high-frequency traders to find information that they can use against other market participants in front-running. ${ }^{323}$ Demand for trading venues that do not disclose information about volumes and prices of orders in the order book has increased as a protection against high-frequency trading, ${ }^{324}$ especially in the US but even in Europe. ${ }^{325}$

Moreover, high-speed trading strategies reduce trade sizes for equity trading, and smaller average trade sizes reduce the market's ability to absorb larger orders without significant price movements. HFT algorithms can detect volume hidden by means of iceberg orders on lit order books. This gives incentives to trade large blocks in dark pools. ${ }^{326}$

319 SEC Release No. 34-61358 (Jan. 14, 2010) (Concept Release on Equity Market Structure), section III.3. See also Kaya O (2016) p 3.

320 Generally, see Fox MB, Glosten LR, Greene EF, Patel MS (2018) p 17.

321 MacIntosh JG (2013).

322 Weild D, Kim E, Newport L (2013) pp 20 -21; Petrescu M, Wedow M (2017) p 10: "However, the presence of HFT can also lead to higher costs of trading for other participants due to predatory practices. For example, one HFT strategy is to use algorithms and high speed to obtain and exploit information about current market supply and demand, especially concerning the presence of large orders. This information can be used for front running some orders, which increases trading costs for investors placing these orders. In some trading venues, high frequency traders pay a premium to receive more detailed order and trading data before it becomes available to other investors, allowing them to incorporate the information in their trading strategies."

323 Petrescu M, Wedow M (2017) pp 10 -11; Shorter G, Miller RS (2014) p 3: "Front-running refers to the practice of trading ahead of a large order to benefit from the anticipated price movement that the large order will create."

324 Petrescu M, Wedow M (2017) p 9: "The growth of dark pools followed an increase in the HFT share of total equities trading in Europe; the share of trades involving HFT grew from a negligible amount to over $30 \%$ by 2009 , and since then has remained around one-third."

325 Ibid., p 20.

326 Ibid., p 20. 
Services. No single venue can serve the interests of all investors. ${ }^{327}$ Dark pools can vary quite widely in the services they offer their customers. Customers include institutional investors and, paradoxically, high-frequency traders.

For institutional investors, liquidity is the key service. ${ }^{328}$ In other words, they want to trade large amounts without altering the price of the asset. ${ }^{329}$ New order types have been created for this purpose. "Immediate or cancel” (IOC) orders require immediate execution and do not invite a matching counter-order for unexecuted portions. The opposite is an "Indication of Interest" (IOI) order that aims to gauge the possibility of finding a matching counter-order but without posting a quote. ${ }^{330}$

However, where trading volumes are small in a dark pool, it can be difficult to attain a critical mass and a sufficient level of liquidity. In the US, this has given dark pool operators incentives to allow proprietary trading or to give informational advantages to high-frequency traders. This practice gives rise to obvious conflicts of interest. ${ }^{331}$

For high-frequency traders, the advancement of dark pools is thus a threat and an opportunity. It is an opportunity, because HFT firms can benefit from the services of dark pools. The key service for high-frequency traders is access to information about large orders to enable front-running. ${ }^{332}$ Because of the interests of high-frequency traders, dark pool operators can have incentives to abuse client trust, give special benefits to high-frequency traders, and breach promises to other clients for profit. ${ }^{333}$

On some trading venues, high-frequency traders pay a premium to receive more detailed order and trading data before it becomes available to other investors, allowing them to incorporate the information in their trading strategies. Predatory practices such as front-running can lead to higher costs of trading for other participants. In the US, many dark pool subscribers became victims of front-running after Regulation NMS created a consolidated market data system and implemented the Order Protection Rule.

\section{Ibid., p 7.}

328 Ibid., p 7.

329 Kaya O (2016) p 3.

330 Gadinis S (2008) p 322.

331 See Aguilar LA (2015); Petrescu M, Wedow M (2017) p 21.

332 Petrescu M, Wedow M (2017) p 10; Shorter G, Miller RS (2014) p 3: "Front-running refers to the practice of trading ahead of a large order to benefit from the anticipated price movement that the large order will create."

333 Petrescu M, Wedow M (2017) p 11; Aguilar LA (2015). 
However, the advancement of dark pools can also pose a threat to the business model of high-frequency traders. This can be illustrated with two episodes of the evolution of HFT. The period before the financial crisis of 2007-2009 was marked by the rise of HFT. After the financial crisis, the market share of HFT in equity trading started to recede. There were several reasons for the decreasing HFT market share such as increased competition, rising costs, regulation, and the emergence of alternative trading platforms. ${ }^{334}$

Ownership. Dark pools can differ in terms of ownership. They can be independently operated, owned by broker-dealers or a consortium of broker-dealers, or even the exchanges themselves. ${ }^{335}$ Where a dark pool operator also operates a traditional (lit) order book exchange, it benefits from access to a ready-made client base. ${ }^{336}$

Trading. Dark pool trading is not homogeneous. It can be organised in different ways ${ }^{337}$ depending on whether trading is one-sided or two-sided, on the order types and matching mechanisms, and on specialisation.

First, dark pools can be based on one-sided trading or two-sided trading. ${ }^{338}$ One-sided trading takes place at a single price (such as the midpoint of the national best bid and offer). At any point in time, dark liquidity only exists on one side (on the buy side or the sell side of a transaction but not both). Two-sided trading takes place at different prices on both the buy and sell sides of the market. These differences can have different market impacts.

Second, dark pools can compete by offering different order types and matching mechanisms: ${ }^{339}$ "As a matter of a fundamental distinction, some display quotes as part of their business model while others do not. Trade execution can take place either automatically or through a negotiation and may occur either throughout the day or at scheduled intervals." 340

Third, dark pools can specialise in a specific client base, in large orders, or in a few equity groups. ${ }^{341}$ "[S]ome dark pools, such as block crossing networks, offer specialized size discovery mechanisms that attempt to bring large buyers

334 Kaya O (2016) p 2.

335 Christiansen H, Koldertsova A (2009) p 228, Box III.3.1; Shorter G, Miller RS (2014) pp 3-4. 336 Petrescu M, Wedow M (2017) p 5.

337 This applies to markets in general. See Ostrom E (2010) p 420.

338 Foley S, Putniņš T (2016); Shorter G, Miller RS (2014) pp 8-9.

339 Petrescu M, Wedow M (2017) p 5.

340 SEC Release No. 34-61358 (Jan. 14, 2010) (Concept Release on Equity Market Structure), section III.3.

341 Petrescu M, Wedow M (2017) p 5. 
and sellers in the same ... stock together anonymously and to facilitate a trade between them". 342

Liquidity. To attract clients, a dark pool requires sufficient liquidity (volumes of orders). There are thus network effects.

On one hand, the existence of network effects could limit the number of dark pools that can be competitive and provide incentives for the consolidation of liquidity to ensure sufficient execution opportunities. ${ }^{343}$

On the other, there is room for a larger number of dark pools if clients accept sufficient liquidity and the maximisation of liquidity is not relevant. For example, the number of dark pools can in that case be increased by specialisation and the differentiation of services offered to clients. ${ }^{344}$ In 2010, the SEC noted that dark pools can vary quite widely in the services they offer their customers and that dark pools that primarily match smaller orders executed more than $90 \%$ of dark pool trading volume. ${ }^{345}$

Transparency. Transparency obviously plays a key role in the business of dark pools that by definition are not supposed to be transparent. Generally, a high level of transparency benefits those market participants that have the best resources to manage information, making transparency to some extent one-sided. ${ }^{346}$ Trade transparency ${ }^{347}$ creates its own problems. Trade transparency that high-frequency traders have used for their own benefit has prejudiced liquidity for all other investors. ${ }^{348}$ It is thus important to manage transparency levels in dark pools. Some exchange-traded funds (ETFs) use limited transparency as a protection against rivals replicating their portfolios or high-speed investors using the information to trade ahead of large orders. ${ }^{349}$

Conclusions. Dark pools can focus on different kinds of clients, use different kinds of order matching methods and pricing methods, and manage transparency in different ways. This may be useful to know when developing new kinds of marketplaces (Chapter 8).

342 SEC Release No. 34-61358 (Jan. 14, 2010) (Concept Release on Equity Market Structure), section III.3.

343 Petrescu M, Wedow M (2017) p 22.

344 Ibid., pp 22-23.

345 SEC Release No. 34-61358 (Jan. 14, 2010) (Concept Release on Equity Market Structure), section III.3.

346 See, for example, Adrian J (2016).

347 See Moloney N (2014) V.1.2.3, p 431 on the function of trade transparency regulation.

348 Ibid., V.1.2.3, pp 431-432 on the trade-off between transparency and liquidity.

349 Richard Henderson, 'Non-transparent' ETFs set to be a boon for fund managers. Financial Times, 19 April 2019. 


\subsubsection{The Regulation of Dark Pools: General Remarks}

The growth of dark pools follows a period of regulatory and technological change. Generally, concentration has contributed to order internalisation by large institutions. ${ }^{350}$ The growth of dark pools in particular can be linked to three developments: the introduction of Regulation NMS in the US, the entry into force of regulations that implemented increased and uniform transparency rules in the EU, and growth in high-frequency trading (HFT) in the US and the EU. ${ }^{351}$

Generally, regulation gives incentives to move trading from exchanges to dark pools in two main ways: by limiting the scope of the regulation of exchanges (increased discretion outside the regulatory regime designed for exchanges, the pull of freedom) and increasing the intensity of the regulation of exchanges (reduced discretion under the regulatory regime designed for exchanges, push).

The regulation of broker-dealer order internalisation and the scope of OTC markets play a key role for the development of alternative venues such as dark pools. Alternative venues cannot provide an alternative, unless they are permitted to exist and their business is feasible. In other words, their business must make legal and commercial sense. Moreover, alternative venues cannot provide an alternative, unless they are subject to a different regulatory framework. They cannot provide an alternative, if they fall within the scope of the same regulatory regime that governs traditional stock exchanges and must comply with the same rules as traditional stock exchanges.

The trend is the expansion of the scope of the regulatory regime for traditional stock exchanges. There is thus less and less room for other kinds of venues. For example, parts of the regulatory regime for traditional exchanges will cover activities in OTC markets as well depending on the nature of market participants, the traded products, the services, and so forth. Examples of this regulatory trend include the 2009 Pittsburgh agreement of G20 leaders, ${ }^{352}$ EMIR, ${ }^{353}$ REMIT, ${ }^{354}$ and MiFID II. ${ }^{355}$

350 Proposal for a Directive of the European Parliament and of the Council on investment services and regulated markets, COM/2002/0625 final, section II.1: "The following technology-driven trends have transformed the financial trading landscape: ... 3. increased internal execution of client orders within investment firms: the concentration of brokerage in the hands of a diminishing number of investment firms and banks is creating a situation in which large volumes of client orders can be executed 'in-house' ...”

351 Petrescu M, Wedow M (2017) p 9. For the regulation of algorithmic trading and HFT in the EU, see Lerch MP (2017).

352 See recital 5 of Regulation 648/2012 (EMIR). 
For regulatory purposes, the main question in the US and the EU is whether dark pools fall within the scope of the definition of ECN or the definition of multilateral trading facility (MFT), respectively. This can influence transparency requirements. In the EU, there are few exemptions from post-trade transparency requirements. Moreover, the main rule is that investment firms must trade on regulated venues in the EU. Dark pools cannot escape many of the regulatory technical standards (RTS) ${ }^{356}$ adopted by the European Commission.

353 Regulation (EU) No 648/2012 of the European Parliament and of the Council of 4 July 2012 on OTC derivatives, central counterparties and trade repositories. See recital 25 of Regulation 648/2012 (EMIR).

354 Regulation (EU) No 1227/2011 of the European Parliament and of the Council of 25 October 2011 on wholesale energy market integrity and transparency. See recitals 5 and 7 of Regulation 1227/2011 (REMIT).

355 See recital 4 of Directive 2014/65/EU (MiFID II). See also Section C of Annex I to MiFID II as well as Article 24 of MiFID II.

356 The Commission Delegated Regulations laying down Regulatory Technical Standards relate, for example, to: package orders (2017/2194); specification of the offering of pre-and posttrade data and the level of disaggregation of data (2017/572); maintenance of relevant data relating to orders in financial instruments (2017/580); reporting of transactions to competent authorities (2017/590); data standards and formats for financial instrument reference data and technical measures in relation to arrangements to be made by the European Securities and Markets Authority and competent authorities (2017/585); the direct, substantial and foreseeable effect of derivative contracts within the Union and the prevention of the evasion of rules and obligations (2017/579); specifying the obligation to clear derivatives traded on regulated markets and timing of acceptance for clearing (2017/582); indirect clearing arrangements (2017/2154); trading obligation for certain derivatives (2017/2417); criteria for determining whether derivatives subject to the clearing obligation should be subject to the trading obligation (2016/2020); regulatory technical standards on access in respect of benchmarks (2016/2021); the information for registration of third-country firms and the format of information to be provided to the clients (2016/ 2022); transparency requirements for trading venues and investment firms in respect of bonds, structured finance products, emission allowances and derivatives trading venues and investment firms in respect of shares, depositary receipts, exchange-traded funds, certificates and other similar financial instruments and on transaction execution obligations in respect of certain shares on a trading venue or by a systematic internaliser (2017/583); the volume cap mechanism and the provision of information for the purposes of transparency and other calculations (2017/577); clearing access in respect of trading venues and central counterparties (2017/581). 


\subsubsection{The Regulation of Dark Pools in the US}

In the US, the SEC distinguishes between four kinds of trading centers (or markets), namely registered exchanges, Electronic Communications Networks (ECNs), dark pools, and broker-dealer internalisation. ${ }^{357}$

The statutory definition of an "exchange" is laid down in Section 3(a)1) of the Securities Exchange Act. ${ }^{358}$ An exchange has to register with the SEC and meet certain statutory requirements. ${ }^{359}$ The terms used in the Exchange Act have been defined by the SEC (see below).

Coined by the SEC in $1998,{ }^{360}$ the term ECN describes a particular way to bring together buying and selling interests in listed stocks and other exchange-traded products. The SEC has defined an ECN "as any electronic system that widely disseminates to third parties orders entered into it by an exchange market maker or OTC market maker, and permits such orders to be executed in whole or in part ..." ${ }^{361}$

Unlike dark pools, ECNs display orders. The term ECN thus refers to "orderdriven systems where the buy and sell orders of investors meet directly in an order book, either in a call auction or in continuous trading". ${ }^{362}$

Dark pools are subject to the same rules that govern trading on an exchange or trading by a broker-dealer. Regulation ATS adopted by the SEC in $1998^{363}$ and

357 SEC Release No. 34-61358 (Jan. 14, 2010) (Concept Release on Equity Market Structure), section III.

358 15 U.S.C. 78c(a)(1).

359 See SEC Release No. 34 - 61358 (Jan. 14, 2010) (Concept Release on Equity Market Structure). 360 SEC Rule 6954(c); SEC Release No. 34-39729; File No. SR-NASD-97-56 (March 6, 1998). 361 See SEC (2000) Part II, I.B. Electronic communications networks are defined in Rule 11Ac1-1 under the Exchange Act, 17 CFR 240.11Ac1-1(a)(8). §240.11Ac1-1(a): "For the purposes of this section: ... (8) The term electronic communications network, for the purposes of §240.11Ac1-1(c)(5), shall mean any electronic system that widely disseminates to third parties orders entered therein by an exchange market maker or OTC market maker, and permits such orders to be executed against in whole or in part; except that the term electronic communications network shall not include: (i) Any system that crosses multiple orders at one or more specified times at a single price set by the ECN (by algorithm or by any derivative pricing mechanism) and does not allow orders to be crossed or executed against directly by participants outside of such times; or (ii) Any system operated by, or on behalf of, an OTC market maker or exchange market maker that executes customer orders primarily against the account of such market maker as principal, other than riskless principal."

362 Christiansen H, Koldertsova A (2009) p 228, Box III.3.1.

363 SEC Release No. 34-40760 (Regulation of Exchanges and Alternative Trading Systems, "Regulation ATS"). 
Regulation NMS adopted by the SEC in $2005^{364}$ are "commonly cited as pivotal in the proliferation of dark pools". ${ }^{365}$

Regulation ATS was designed to "facilitate an appropriately balanced market structure". On one hand, the regulatory framework must "provide for strong investor protection and enable businesses to raise the capital they need to grow". On the other, it must "encourage market innovation while ensuring basic investor protections".366

In the new Rule $3 \mathrm{~b}-16$ of Regulation ATS, the SEC interpreted key language in the statutory definition of "exchange" under the Exchange $\mathrm{Act}^{367}$ in a new way. According to the SEC, the rule change was necessary because of automated trading and technological development. Rule 3b-16 therefore "defines terms in the statutory definition of exchange to include markets that engage in activities functionally equivalent to markets currently registered as national securities exchanges". 368

Rule 3b-16 explicitly excludes those systems that the SEC believes perform only traditional broker-dealer activities. Rule 3a1-1 exempted most alternative trading systems from the definition of "exchange" and therefore the requirement to register as an exchange. However, any system exercising self-regulatory powers must register as an exchange or be operated by a national securities association, because self-regulatory activities in the securities markets must be subject to SEC oversight under the Exchange Act. ${ }^{369}$

Regulation ATS thus allowed "most alternative trading systems to choose to be regulated either as exchanges or as broker-dealers", depending on whether they chose to comply with Regulation ATS or not. ${ }^{370}$

Regulation ATS requires alternative trading systems with significant volume to display their best-priced orders for securities in which they have 5 percent or more of total trading volume in the public quote. ${ }^{371}$ In practice, most individual dark pools are exempted from this requirement. Unlike exchanges, they are thus not required to disclose ongoing offers to buy or sell stocks to the public. ${ }^{372}$

364 SEC Release No. 34-51808 (Regulation NMS).

365 Shorter G, Miller RS (2014) p 5.

366 Regulation ATS, section II.

367 Section 3(a)(1) of the Exchange Act.

368 See Regulation ATS, section III on the function of Rule 3b-16.

369 Ibid., II.B.

370 Ibid., II.B.

371 Regulation ATS, section IX.A.2.b; Shorter G, Miller RS (2014) p 5.

372 Shorter G, Miller RS (2014) p 5: "Dark pools are subject to the same rules that govern trading on an exchange or by a broker-dealer. However, unlike exchanges, they are not required to publicize ongoing offers to buy or sell stocks, called quotes.” 
Regulation $\mathrm{NMS}^{373}$ contains substantive rules designed to change the structure of US equity markets. Regulation NMS has been described as "a watershed event” for US equity markets as it abolished rules that had protected the manual quotation systems of incumbent exchanges. ${ }^{374}$

For dark pools, the most important rules are the order protection rule, the access rule and the market data rules. The purpose of order protection rules was to prevent the execution of trades at prices inferior to protected quotations displayed by other trading centers, subject to an applicable exception. To be protected, a quotation must be immediately and automatically accessible. The access rule requires fair and non-discriminatory access to quotations. Amendments to the market data rule changed the requirements for consolidating, distributing, and displaying market information. ${ }^{375}$

Regulation NMS contributed to a fragmented trading marketplace that could be exploited by HFT firms. The order protection rule aimed at ensuring that investors receive the best buy or sell price when their orders are executed by eliminating the ability to have orders "traded through" (that is, executed at a worse price). The access rule required better market center linkages and lower access fees. The market data rule required market centers to route orders for execution to the market center that shows the best price. ${ }^{376}$

Conclusion. The growth of dark pools in the US was driven by regulation. The consolidated market data system created a major difference between exchanges and dark pools. While this system collects "consolidated quotation data" and "consolidated trade data", there are exemptions from the duty to disclose information about quotations. ${ }^{377}$ The business of dark pools is facilitated by such exemptions from pre-trade transparency requirements. Moreover, Regulation NMS fostered competition between venues but not the kind of competition that would directly have benefited market investors and issuers. Regulation NMS did not increase the competition for best prices and liquidity between lit venues. Instead, it fostered competition in terms of speed, fees, and the availability of exotic order types. Scanning venues for prices and the actual routing of orders across venues could increase the time for execution, the risk of information leakage, and the

\footnotetext{
373 SEC Release No. 34-51808 (Regulation NMS).

374 Zhu H (2014).

375 Regulation NMS, Summary.

376 Shorter G, Miller RS (2014) p 6.

377 SEC Release No. 34-61358 (Jan. 14, 2010) (Concept Release on Equity Market Structure), section III.B.1.
} 
business opportunities of HFT firms. ${ }^{378}$ Problems with dark pools led to several enforcement actions by the SEC. ${ }^{379}$

\subsubsection{The Regulation of Broker-Dealer Internalisation in the US}

Regulation ATS allows alternative trading systems to choose to be regulated either as exchanges or as broker-dealers. ${ }^{380}$ Where a broker-dealer prefers not to act as an exchange (a market), it can act as a market participant in the OTC market by internalising customer order flows. ${ }^{381}$ The SEC's definition of an ECN excludes internal broker-dealer order-routing systems and crossing systems. ${ }^{382}$

There are many broker-dealers that execute trades internally in NMS stocks in the US. ${ }^{383}$ Such broker-dealers generally fall into two categories, namely OTC market makers and block positioners.

An OTC market maker is defined as "any dealer that holds itself out as being willing to buy and sell to its customers, or others, in the United States, an NMS stock for its own account on a regular or continuous basis otherwise than on a national securities exchange in amounts of less than block size."384

According to the SEC, a block positioner generally means "any broker-dealer in the business of executing, as principal or agent, block size trades for its customers". 385 "Block size" means an order of at least 10,000 shares or for a quantity of stock having a market value of at least $\$ 200,000$. $^{386}$

378 Petrescu M, Wedow M (2017) pp 20 -21.

379 See In the Matter of Pipeline Trading Systems LLC, et al., Exchange Act Release No. 65609 (October 24, 2011); In the Matter of eBX, LLC, Exchange Act Release No. 67969 (October 3, 2012); In the Matter of Liquidnet, Inc., Exchange Act Release No. 72339 (June 6, 2014); In the Matter of ITG Inc. and Alternet Securities, Inc., Exchange Act Release No. 75672 (Aug. 12, 2015); In the Matter of UBS Securities LLC, Exchange Act Release No. 74060 (Jan. 15, 2015). See also Aguilar LA (2015); Hintz A (2015).

380 See SEC (2000) Part II, I.C.

381 Ibid., Part II, I.C: “In connection with the New York Stock Exchange's proposal to eliminate its rule limiting its members from dealing in its listed stocks, the Commission requested comment on the impact of fragmentation, particularly that arising from internalization of customer order flow."

382 See ibid., Part II, I.B and footnote 10.

383 SEC Release No. 34-61358 (Jan. 14, 2010) (Concept Release on Equity Market Structure), section III.4.

384 Rule 600(b)(52) of Regulation NMS; Concept Release on Equity Market Structure, section III.4.

385 Concept Release on Equity Market Structure, section III.4. 
Broker-dealers that act as OTC market makers or block positioners conduct their business primarily by directly negotiating with customers or with other broker-dealers representing customer orders. ${ }^{387}$

\subsubsection{The Regulation of Dark Pools in EU Law}

In the EU, the regulation of dark pools may have multiple objectives. The main concern seems to be whether there is a level playing field for dark pools and traditional marketplaces. ${ }^{388}$

The business of dark pools is affected and in effect limited by: constraints on the rights of "investment firms" 389 to choose on which venues to trade; the large scope of pre-trade disclosure obligations; and the large scope of post-trade disclosure obligations. Competent authorities may waive pre-trade disclosure obligations under certain circumstances. This is significant for the business of dark pools.

Trading obligation for investment firms in the EU. In the EU, investment firms are not free to choose the venue for the trading of shares. If shares are admitted to trading on a regulated market or traded on a trading venue, the main rule is that an investment firm that trades in such shares must use a regulated market, an MTF, a systematic internaliser, or a third-country trading venue assessed as equivalent. ${ }^{390}$

However, there is no such trading obligation, where the trades: “(a) are nonsystematic, ad-hoc, irregular and infrequent; or (b) are carried out between eligible and/or professional counterparties and do not contribute to the price discovery process". 391

For professional counterparties, the question thus is whether the trades "contribute to the price discovery process". Transactions not contributing to the price discovery process have been defined in Commission Delegated Regula-

386 Rule 600(b)(9) of Regulation NMS; Concept Release on Equity Market Structure, section III.4.

387 Concept Release on Equity Market Structure, section III.4.

388 Moloney N (2014) V.1.2.4, pp 433-434: "Dark trading in the equity markets is not troublesome in itself. The benefits to investors include liquidity provision, price impact protection, and lower execution costs. The difficulties arise where dark equity trading is of a similar functionality to lit equity trading ..."

389 Point (1) of Article 4(1) of Directive 2014/65/EU (MiFID II).

390 Article 23(1) of Regulation (EU) 600/2014 (MiFIR).

391 Article 23(1) of Regulation (EU) 600/2014 (MiFIR). 
tion (EU) 2017/587. A transaction in shares does not contribute to the price discovery process where any of the circumstances listed in the Delegated Regulaton apply. For example, such transactions include: many transactions with a reference price; ${ }^{392}$ transactions that are part of a "portfolio trade", 393 that is, "transactions in five or more different financial instruments where those transactions are traded at the same time by the same client and as a single lot against a specific reference price"; ${ }^{394}$ many transactions connected to derivatives ${ }^{395}$ or transactions that are "securities financing transactions"; 396 and many transactions of a technical nature. ${ }^{397}$

In practice, many derivatives transactions can "contribute to the price discovery process”. In March 2020, a Financial Times article summed up what happens when traders use volatility as a proxy for risk: "[U]sing volatility as shorthand for risk means that when markets are calm, traders have carte blanche to buy securities. Conversely, when turbulence erupts, traders are forced to ratchet back their positions, exacerbating the very phenomenon they are responding to." 398

Post-trade transparency in the EU. Under MiFID, dark pools and lit venues did not differ in the level of post-trade transparency. While there were exemptions from pre-trade transparency under a Commission Regulation ${ }^{399}$ implementing MiFID, there were no exemptions regarding post-trade transparency. ${ }^{400}$

392 Point (a) of Article 2 of Commission Delegated Regulation (EU) 2017/587.

393 Point (b) of Article 2 and point (1) of Article 1 of Commission Delegated Regulation (EU) 2017/587.

394 Point (1) of Article 1 of Commission Delegated Regulation (EU) 2017/587.

395 Points (c) and (g) of Article 2 of Commission Delegated Regulation (EU) 2017/587.

396 Point (h) of Article 2 and point (3) of Article 1 of Commission Delegated Regulation (EU) 2017/587. See Regulation (EU) 2015/2365 of the European Parliament and of the Council of 25 November 2015 on transparency of securities financing transactions and of reuse and amending Regulation (EU) No 648/2012. Point (11) of Article 3 of Regulation (EU) 2015/2365 (SFTR) on the definition of a "securities financing transaction" or "SFT".

397 Points (d), (f), (g) and (i) of Article 2 of Commission Delegated Regulation (EU) 2017/587. See also point (2) of Article 1 of Commission Delegated Regulation (EU) 2017/587.

398 Robin Wigglesworth, Coronavirus mayhem reflects phenomenon of 'schock-led' markets. Financial Times, 6 March 2020.

399 Commission Regulation (EC) No 1287/2006 of 10 August 2006 implementing Directive 2004/ 39/EC of the European Parliament and of the Council as regards record-keeping obligations for investment firms, transaction reporting, market transparency, admission of financial instruments to trading, and defined terms for the purposes of that Directive.

400 See Article 29(2) of Regulation (EC) 1287/2006. See also Petrescu M, Wedow M (2017) p 16 footnote 37: "Dark pools and lit venues do not, however, differ in the level of post-trade trans- 
MiFID was felt to have contained loopholes. ${ }^{401}$ To close some of the loopholes, MiFID II required the use of approved publication arrangements (APAs) 402 "to improve the quality of trade transparency information published in the OTC space". 403

MiFID II is complemented by MiFIR ${ }^{404}$ that requires public post-trade disclosure. MiFIR lays down directly applicable post-trade transparency requirements for trading venues in respect of shares. ${ }^{405}$ According to the main rule, market operators and investment firms operating a trading venue must make details of share transactions public "as close to real-time as is technically possible". ${ }^{406}$

Moreover, MiFIR lays down post-trade transparency requirements for investment firms where they trade in financial instruments traded on a trading venue. These post-trade transparency requirements apply not only to transactions executed on a trading venue but even to transactions executed via a systematic internaliser or OTC. ${ }^{407}$ Investment firms must make public disclosures through an APA. ${ }^{408}$ MiFID II defines the information that must be made public by an APA ${ }^{409}$ and the way that an APA should make information public. According to MiFID II, an APA should make the required information public "as close to real time as is technically possible, on a reasonable commercial basis", and it should be made available "free of charge 15 minutes after the APA has published it" ${ }^{410}$ Under Commission Delegated Regulation (EU) 2017/587, "as close to real time as is technically possible" customarily means "in any case within one minute of the relevant transaction" for transactions that take place during normal trading hours. ${ }^{411}$

Since not only trading venues but even investment firms have post-trade transparency obligations, transactions executed on an alternative venue or out-

parency; all are currently required to report as close to real time as possible, at most within three minutes."

401 Recital 4 of Regulation (EU) 600/2014 (MiFIR).

402 Point (52) of Article 4(1) of Directive 2014/65/EU (MiFID II).

403 Recital 116 of Directive 2014/65/EU (MiFID II). See also recital 117.

404 Regulation (EU) No 600/2014 of the European Parliament and of the Council of 15 May 2014 on markets in financial instruments and amending Regulation (EU) No 648/2012.

405 Recital 5 and Article 6 of Regulation (EU) 600/2014 (MiFIR); Article 12 of Commission Delegated Regulation (EU) 2017/587.

406 Article 6(1) of Regulation (EU) 600/2014 (MiFIR).

407 See, for example, point (g) of Article 64(2) of Directive 2014/65/EU (MiFID II).

408 Article 20(1) of Regulation (EU) 600/2014 (MiFIR).

409 Article 64(2) of Directive 2014/65/EU (MiFID II). See also recital 13 of Commission Delegated Regulation (EU) 2017/587.

410 Article 64(1) of Directive 2014/65/EU (MiFID II); Article 6(1) of Regulation (EU) 600/2014 (MiFIR).

411 Article 14 of Commission Delegated Regulation (EU) 2017/587. 
side the rules of a trading venue will not escape post-trade transparency requirements. The transaction must be made public by a participating investment firm $^{412}$ or systematic internaliser. ${ }^{413}$ If the transaction is between two investment firms, either on own account or on behalf of clients, the transaction must be made public through an APA by the seller. ${ }^{414}$ The time limit basically is the same for transactions that take place on a trading venue $\mathrm{e}^{415}$ and transactions that take place outside a trading venue. ${ }^{416}$ A single transaction must not be made public as multiple trades. ${ }^{417}$

There are few exemptions from post-trade transparency requirements. The transactions that benefit from the exemptions mainly are of a technical nature. ${ }^{418}$

MiFIR permits deferred publication only with the prior approval of the competent authority. In particular, "the competent authorities may authorise the deferred publication in respect of transactions that are large in scale compared with the normal market size" for the share. ${ }^{419}$ ESMA was required to develop technical standards for deferred publication. ${ }^{420}$ In 2015, ESMA published draft regulatory and implementing standards in a Final Report ${ }^{421}$ that included a post-trading standard ${ }^{422}$ and particular large in scale thresholds for deferred post-trade transparency in share trading. ${ }^{423}$ Of the many regulatory technical standards (RTS) adopted by the Commission, Commission Delegated Regulation (EU) $2017 / 587^{424}$ is particularly relevant for trading in shares, share trading venues, and systematic internalisers. It is based on the draft regulatory technical standards submitted by the ESMA to the Commission. ${ }^{425}$

412 Recital 15 of Commission Delegated Regulation (EU) 2017/587.

413 Recital 16 of Commission Delegated Regulation (EU) 2017/587.

414 Article 12(4) of Commission Delegated Regulation (EU) 2017/587.

415 Article 14(1) of Commission Delegated Regulation (EU) 2017/587.

416 Article 14(2) of Commission Delegated Regulation (EU) 2017/587.

417 Recital 17 and Article 12(6) of Commission Delegated Regulation (EU) 2017/587.

418 Article 13 of Commission Delegated Regulation (EU) 2017/587.

419 Article 7(1) of Regulation (EU) 600/2014 (MiFIR).

420 Article 7(2) of Regulation (EU) 600/2014 (MiFIR).

421 ESMA (2015).

422 Section 2.1.4 of ESMA (2015).

423 Chapter V of section 2.1.4 of ESMA (2015).

424 Commission Delegated Regulation (EU) 2017/587 of 14 July 2016 supplementing Regulation (EU) No 600/2014 of the European Parliament and of the Council on markets in financial instruments with regard to regulatory technical standards on transparency requirements for trading venues and investment firms in respect of shares, depositary receipts, exchange-traded funds, certificates and other similar financial instruments and on transaction execution obligations in respect of certain shares on a trading venue or by a systematic internaliser.

425 Recital 20 of Commission Delegated Regulation (EU) 2017/587. 
According to the main rule on post-trade transparency, information is required to be made available "as close to real time as possible" and it should be made available "as instantaneously as technically possible, assuming a reasonable level of efficiency and of expenditure on systems on the part of the person concerned". Moreover, the information should only be published close to the prescribed maximum time limit "in exceptional cases where the systems available do not allow for publication in a shorter period of time". ${ }^{426}$

While a high degree of transparency is regarded as essential, ${ }^{427}$ it is recognised that deferrals from post-trade transparency obligations should be provided under some circumstances "to avoid the impairment of liquidity as an unintended consequence of obligations to disclose orders and transactions and thereby to make public risk positions". ${ }^{428}$ Where competent authorities authorize the deferral of post-trade information, "all regulated markets, multilateral trading facilities and investment firms trading outside of trading venues" should be treated "equally and in a non-discriminatory manner". ${ }^{429}$ Moreover, the post-trade transparency regime "should be appropriately calibrated to the market and applied in a uniform manner throughout the Union".430

The modalities of referrals and maximum time limits are set out in Commission Delegated Regulation (EU) 2017/587. ${ }^{431}$

Pre-trade transparency in the EU. The regulation of pre-trade and post-trade transparency in equities trading under MiFID strengthened demand for dark pools in the EU. ${ }^{432}$ As regards pre-trade transparency requirements for regulated markets and MTFs, MiFID made it mandatory to disclose the bid and offer prices and depth of interest (volumes in the order book at different prices) on a continuous basis for equity and equity-like instruments. ${ }^{433}$ Pre-trade transparency requirements increased risks for many market participants: "Such pre-trade transparency requirements increase the probability that information about larger orders in the order book can be detected by predatory traders, which could be costly to investors if it resulted in front running." ${ }^{434}$ MiFID therefore permitted

426 Recital 12 of Commission Delegated Regulation (EU) 2017/587.

427 Recital 1 of Commission Delegated Regulation (EU) 2017/587.

428 Recital 2 of Commission Delegated Regulation (EU) 2017/587.

429 Recital 4 of Commission Delegated Regulation (EU) 2017/587.

430 Recital 9 of Commission Delegated Regulation (EU) 2017/587.

431 Article 15 of Commission Delegated Regulation (EU) 2017/587.

432 Petrescu M, Wedow M (2017) p 13.

433 Article 29(1) of Directive 2004/39/EC (MiFID).

434 Petrescu M, Wedow M (2017) p 13. 
waivers from pre-trade transparency. ${ }^{435}$ Waivers are important for traders that may need to protect orders from information leakage and front running by hiding some information from other market participants.

The pre-trade transparency and waiver regime was changed by MiFIR. Like MiFID, MiFIR lays down pre-trade transparency obligations ${ }^{436}$ calibrated for different kinds of trading systems. ${ }^{437}$ Competent authorities may waive the obligation for market operators and investment firms operating a trading venue under certain circumstances. MiFIR permits waivers for the following systems or orders: - subject to the so-called volume cap mechanism, ${ }^{438}$ systems in which the price is derived from a particular widely published and reliable reference price; 439

- to some extent subject to the volume cap mechanism, ${ }^{440}$ systems that formalise particular negotiated transactions; $;^{441}$

- orders that are large in scale compared with normal market size; ${ }^{442}$ and

- orders held in an order management facility of the trading venue pending disclosure. ${ }^{443}$

To properly understand the MiFIR waiver regime, we can have a look at the earlier MiFID regime. The MiFID regime permitted the waiving of pre-trade disclosure obligations in the same contexts. ${ }^{444}$ The waivers were thus based on order size (large-in-scale waivers), market model and transaction type (reference

435 Article 29(2) of Directive 2004/39/EC (MiFID). For implementing measures, see Article 29(3) of Directive 2004/39/EC (MiFID).

436 Article 3(1) of Regulation (EU) 600/2014 (MiFIR).

437 Article 3(2) of Regulation (EU) 600/2014 (MiFIR): "The transparency requirements referred to in paragraph 1 shall be calibrated for different types of trading systems including order-book, quote-driven, hybrid and periodic auction trading systems." See also Article 3 of Commission Delegated Regulation (EU) 2017/577.

438 First subparagraph of Article 5(1) of Regulation (EU) 600/2014 (MiFIR).

439 Article 4(1) of Regulation (EU) 600/2014 (MiFIR).

440 First subparagraph of Article 5(1) of Regulation (EU) 600/2014 (MiFIR).

441 Point (b) of Article 4(1) of Regulation (EU) 600/2014 (MiFIR). See also second subparagraph of Article 5(1).

442 Points (c) and (d) of Article 4(1) of Regulation (EU) 600/2014 (MiFIR).

443 Point (d) of Article 4(1) of Regulation (EU) 600/2014 (MiFIR).

444 Article 29 of Directive 2004/39/EC (MiFID); Commission Regulation (EC) No 1287/2006 of 10 August 2006 implementing Directive 2004/39/EC of the European Parliament and of the Council as regards record-keeping obligations for investment firms, transaction reporting, market transparency, admission of financial instruments to trading, and defined terms for the purposes of that Directive. 
price waivers and negotiated price waivers), ${ }^{445}$ and orders held in an order management system by a regulated market or MTF pending disclosure to the market (order management waivers). ${ }^{446}$

This MiFID package of waivers formed a system where each waiver type addressed a particular concern. First, large orders are not only costly to execute immediately in the absence of sufficient liquidity but even particularly vulnerable to front running if they are subject to pre-trade transparency while sitting in the order book. ${ }^{447}$ This made large-in-scale waivers necessary. Second, all transactions do not qualify for large-in-scale waivers. A reference price waiver covers all transactions on the venue. Since the MiFID regime permitted this waiver for the entire trading system and all orders in the order book regardless of size, most dark pools in Europe rely on this waiver. ${ }^{448}$ Third, negotiated price waivers are useful for retail trading platforms or large pre-agreed block trades. ${ }^{449}$ Fourth, the waiver from pre-trade transparency for orders held in an order management system facilitated the use of special hidden or part-hidden order types such as iceberg orders for large orders in lit order books. In iceberg orders, only a small part of the volume is displayed at one time. The MiFID regime thus enabled traders to hide information in lit order books. ${ }^{450}$ This did not prevent algorithmic traders from developing methods to detect hidden volumes in lit order books. ${ }^{451}$

MiFIR imposed restrictions on the use of some of these waivers. While the use of the large-in-scale waiver is not restricted under MiFIR, the reference price and negotiated transaction waivers are subject to the volume cap mechanism or "double volume cap". ${ }^{452}$ In other words, they are constrained by the usage of the reference price and negotiated price waivers on individual venues and on all venues in the EU.

The volume cap mechanism thresholds of $4 \% 0^{453}$ and $8 \%{ }^{454}$ are likely to affect trading on dark pools for some instruments. In 2016, the volume traded on

445 Article 18(1) of Regulation 1287/2006 (implementing MiFID).

446 Article 18(2) of Regulation 1287/2006 (implementing MiFID).

447 Petrescu M, Wedow M (2017) p 13.

448 Ibid., p 14.

449 Ibid., p 14.

450 Ibid., pp $13-14$.

451 Ibid., pp $13-14$ and 20.

452 See ibid., p 15 describing the double volume cap mechanism. Article 5(1) of Regulation (EU) 600/2014 (MiFIR).

453 Point (a) of the first subparagraph of Article 5(1) of Regulation (EU) 600/2014 (MiFIR).

454 Point (b) of the first subparagraph of Article 5(1) of Regulation (EU) 600/2014 (MiFIR). 
dark pools accounted for over $8 \%$ of the total value traded in equities in the EU. ${ }^{455}$

The thresholds can affect the structure of the European dark pool market. Since the large-in-scale waiver is not affected but the use of some waivers is limited, the new restrictions under MiFIR are "likely to have different effects on the market share of different dark pools, depending on whether the venues cater for large orders". The volume cap mechanism "might lead to a shift towards larger trades in dark pools". Moreover, traders may not be as free as before to place small orders in the dark. Consequently, the market share and competitiveness of dark pools focused on small-order venues might suffer. This might lead to "consolidation in the dark pools serving small-sized orders". ${ }^{456}$

The regulatory technical standards have been laid down in Commision Delegated Regulation 2017/577. The Commission Delegated Regulation defines, for example:

- how market operators and investment firms operating a trading venue shall make public the range of bid and offer prices and the depth of trading interest at those prices; ${ }^{457}$

- the most relevant market in terms of liquidity; ${ }^{458}$

- the specific characteristics of negotiated transactions ${ }^{459}$ and negotiated transactions subject to conditions other than the current market price; ${ }^{460}$

- orders that are large in scale; ${ }^{461}$ and

- the type and minimum size of orders held in an order management facility. ${ }^{462}$

There are particular pre-trade transparency requirements under MiFIR for systematic internalisers and investment firms when they trade in shares OTC (that is, outside a trading venue $)^{463}$ and in sizes up to standard market size. These par-

455 Petrescu M, Wedow M (2017) pp 15 and 22. See also the monthly LiquidMetrix Guide to European Dark Pools.

456 Petrescu M, Wedow M (2017) pp 15-16.

457 Article 3 of Commission Delegated Regulation (EU) 2017/577.

458 Article 4 of Commission Delegated Regulation (EU) 2017/577.

459 Article 5(1) of Commission Delegated Regulation (EU) 2017/577.

460 Article 6 of Commission Delegated Regulation (EU) 2017/577.

461 Article 7 of Commission Delegated Regulation (EU) 2017/577.

462 Article 8 of Commission Delegated Regulation (EU) 2017/577.

463 Title III, Articles 14-17 of Regulation (EU) 600/2014 (MiFIR). 
ticular requirements thus do not apply when systematic internalisers deal in sizes above standard market size. ${ }^{464}$

The main rule is that investment firms must make public firm quotes provided that there is a liquid market: "Investment firms shall make public firm quotes in respect of those shares, depositary receipts, ETFs, certificates and other similar financial instruments traded on a trading venue for which they are systematic internalisers and for which there is a liquid market." ${ }^{465}$ In the absence of a liquid market, systematic internalisers shall disclose quotes to their clients upon request. ${ }^{466}$

The Commission has defined these requirements in greater detail in the Commission Delegated Regulation as required by MiFIR. ${ }^{467}$ The Delegated Regulation addresses: arrangements for the publication of a firm quote; ${ }^{468}$ prices reflecting prevailing market conditions; ${ }^{469}$ and the standard market size. ${ }^{470}$

There are particular rules on access to quotes. In effect, they can make the business of HFT firms more difficult. The main rule is that systematic internalisers may decide the clients to whom they give access to their quotes. They may do this "on the basis of their commercial policy and in an objective non-discriminatory way" and on the basis of "clear standards for governing access to their quotes". ${ }^{471}$ Moreover, to limit the risk of exposure to multiple transactions from the same client, systematic internalisers may limit in a non-discriminatory way the number of transactions from the same client which they undertake to enter at the published conditions. ${ }^{472}$

Conclusion. In the EU, the main design principle for the regulation of dark pools is ensuring a level playing field for venues and investment firms. The most important issues relate to pre-trade and post-trade transparency. MiFIR provides for a waiver regime subject to a volume cap mechanism. MiFIR is expected to influence the structure of the dark pool market. The regulation of dark pools is

464 Article 14(2) of Regulation (EU) 600/2014 (MiFIR): “This Article and Articles 15, 16 and 17 shall apply to systematic internalisers when they deal in sizes up to standard market size. Systematic internalisers shall not be subject to this Article and Articles 15, 16 and 17 when they deal in sizes above standard market size.”

465 First subparagraph of Article 14(1) of Regulation (EU) 600/2014 (MiFIR).

466 Second subparagraph of Article 14(1) of Regulation (EU) 600/2014 (MiFIR).

467 Article 17(3) of Regulation (EU) 600/2014 (MiFIR).

468 Article 9 of Commission Delegated Regulation (EU) 2017/577.

469 Article 10 of Commission Delegated Regulation (EU) 2017/577.

470 Article 11 of Commission Delegated Regulation (EU) 2017/577.

471 Article 17(1) of Regulation (EU) 600/2014 (MiFIR).

472 Article 17(2) of Regulation (EU) 600/2014 (MiFIR). 
influenced by the regulation of so-called systematic internalisers (section 3.4.7). The interests of issuer-firms have not mattered.

\subsubsection{The Regulation of Systematic Internalisers in EU Law}

A dark pool is not a normative concept in EU law. Whether a dark pool is permitted or not depends on the facts of the case, that is, the dark pool. Authorisation requirements for multilateral trading facilities (MTFs) or investment firms may apply. A dark pool is not regarded as an MTF if the operator of a dark pool is regarded as a systematic internaliser.

In the EU, the definition of a multilateral trading facility (MTF) under MiFID II does not include "systematic internalisers". The operator or a dark pool or any other alternative venue can thus choose to act as a systematic internaliser. ${ }^{473}$ Since this term can influence market organisation, we can have a brief look at the relevant chain of definitions.

The first definition in the chain is "a multilateral trading system" or "multilateral system”. A "multilateral system" means "any system or facility in which multiple third-party buying and selling trading interests in financial instruments are able to interact in the system". ${ }^{474}$ This definition is quite a broad one as it refers to "any system or facility" and the rather broad definition of "financial instruments". ${ }^{475}$ However, the definition is limited to "interaction in the system" of "multiple third-party buying and selling trading interests".

Such a multilateral trading system for the trading of shares can be a "regulated market" 476 or a "multilateral trading facility". A "multilateral trading facility" means "a multilateral system, operated by an investment firm or a market operator, which brings together multiple third-party buying and selling interests in financial instruments - in the system and in accordance with non-discretionary rules - in a way that results in a contract in accordance with Title II of [MiFID II]". 477 The most important part of the definition is the existence of "non-discretionary rules". ${ }^{478}$ The operation of such a multilateral system requires an authorisation. ${ }^{479}$

473 Recital 17 of Directive 2014/65/EU (MiFID II).

474 Point (19) of Article 4(1) of Directive 2014/65/EU (MiFID II).

475 Section B of Annex I to Directive 2014/65/EU (MiFID II).

476 Point (21) of Article 4(1) of Directive 2014/65/EU (MiFID II).

477 Point (22) of Article 4(1) of Directive 2014/65/EU (MiFID II).

478 Article 19(1) of Directive 2014/65/EU (MiFID II). 
Now, the activity of "systematic internalisers" is not regarded as the operation of a "multilateral trading facility". A systematic internaliser has been defined in MiFID II as "an investment firm which, on an organised, frequent, systematic and substantial basis, deals on own account by executing client orders outside [regulated trading venues] and without operating a multilateral system". ${ }^{480}$ A systematic internaliser is thus "an investment firm" and needs an authorisation. ${ }^{481}$ The activity of a systematic internaliser is done "on an organised, frequent, systematic and substantial basis". However, the activity of a systematic internaliser must not be based on "non-discretionary rules", and "multiple thirdparty buying and selling trading interests" must not "interact in the system".

There is a more detailed definition in Commission Delegated Regulation (EU) 2017/565. ${ }^{482}$ According to the recitals of the Delegated Regulation, "a systematic internaliser should not be allowed to bring together third party buying and selling interests in functionally the same way as a trading venue. A systematic internaliser should not consist of an internal matching system which executes client orders on a multilateral basis, an activity which requires authorisation as a multilateral trading facility (MTF). An internal matching system in this context is a system for matching client orders which results in the investment firm undertaking matched principal transactions on a regular and not occasional basis." 483 The key difference between the operation of a multilateral trading facility and the activities of a systematic internaliser is thus that a systematic internaliser must not have an internal matching system matching orders on a multilateral basis.

479 Article 5(1) of Directive 2014/65/EU (MiFID II): "Each Member State shall require that the provision of investment services and/or the performance of investment activities as a regular occupation or business on a professional basis be subject to prior authorisation in accordance with this Chapter. Such authorisation shall be granted by the home Member State competent authority designated in accordance with Article 67." Article 5(2) of Directive 2014/65/EU (MiFID II): "By way of derogation from paragraph 1, Member States shall authorise any market operator to operate an MTF or an OTF, subject to the prior verification of their compliance with this Chapter." 480 Point (20) of Article 4(1) of Directive 2014/65/EU (MiFID II). See also recital 17 of Directive 2014/65/EU (MiFID II) on the definition of systematic internalisers. A "trading venue" is defined in point (24) of Article 4(1) of Directive 2014/65/EU (MiFID II).

481 Article 5(1) of Directive 2014/65/EU (MiFID II): "Each Member State shall require that the provision of investment services and/or the performance of investment activities as a regular occupation or business on a professional basis be subject to prior authorisation in accordance with this Chapter. Such authorisation shall be granted by the home Member State competent authority designated in accordance with Article 67."

482 See Article 12 of Regulation (EU) 2017/565.

483 Recital 19 of Regulation (EU) 2017/565. 
One can draw the conclusion that systematic internalisers cannot become alternative venues and functional equivalents to stock exchanges.

\subsubsection{The Regulation of High-Frequency Trading}

It is useful to have a brief look at the regulation of high-frequency trading (HFT). Any alternative venue designed to foster the interests of issuer-firms should address the problem of HFT.

Regulators in the US and the EU addressed HFT after the Flash Crash in May 2010. The market share of HFT in equity trading decreased due to regulation, increased competition, rising costs, and the emergence of alternative trading platforms. ${ }^{484}$

The regulation of HFT in the EU. In the EU, MiFID II imposed stricter requirements on trading venues and market participants that engage in algorithmic or high-frequency trading.

The provisions addressing algorithmic trading are motivated in the recitals of MiFID II in relatively great length. It is recognised that "[m]any market participants now make use of algorithmic trading" and that "[r]isks arising from algorithmic trading should be regulated". ${ }^{485}$ The particular characteristics of highfrequency algorithmic trading ${ }^{486}$ have given rise to characteristic problems ${ }^{487}$ that MiFID II is designed to address "by a combination of measures and specific risk controls directed at firms that engage in algorithmic trading or high-frequency algorithmic trading techniques, those that provide direct electronic access, and other measures directed at operators of trading venues that are accessed by such firms". 488

These measures include, first, the duty of investment firms and trading venues to ensure that "robust measures are in place to ensure that algorithmic trading or high-frequency algorithmic trading techniques do not create a disorderly market and cannot be used for abusive purposes" ${ }^{489}$ and, second, the duty of trading venues to ensure that "the fee structures of trading venues are transparent, non-discriminatory and fair and that they are not structured in such a way as to promote disorderly market conditions”. Third, it is stated in the recitals that

\footnotetext{
484 Kaya O (2016) p 2.

485 Recital 59 of Directive 2014/65/EU (MiFID II).

486 Recital 61 of Directive 2014/65/EU (MiFID II).

487 Recital 62 of Directive 2014/65/EU (MiFID II).

488 Recital 63 of Directive 2014/65/EU (MiFID II).

489 Recital 64 of Directive 2014/65/EU (MiFID II).
} 
"Member States should also be able to allow trading venues to impose higher fees for placing orders that are subsequently cancelled or on participants placing a high ratio of cancelled orders and on those operating a high-frequency algorithmic trading technique in order to reflect the additional burden on system capacity without necessarily benefitting other market participants". ${ }^{490}$ Fourth, it is regarded as "appropriate to ban the provision of direct electronic access to markets by investment firms for their clients where such access is not subject to proper systems and controls". ${ }^{491}$ Fifth, all orders generated by algorithmic trading must be flagged. ${ }^{492}$ Sixth, "investment firms that engage in algorithmic trading to pursue a market making strategy should have written agreements in place with trading venues clarifying their obligations to provide liquidity to the market”. ${ }^{493}$ Seventh, some HFT practices could constitute market abuse. ${ }^{494}$

MiFID II applies to high-frequency trading in shares even where the trader deals on own account. ${ }^{495}$ Article 17 of MiFID II lays down the key obligations. For example, MiFID II requires "speed bumps that artificially slow down the trade order speeds, order-to-trade ratios that prevent overly rapid and frequent submitting and cancelling of orders as well as systems and risk controls to ensure resilience of venues. Also included in MiFID 2 are direct market access limits and algorithm disclosure requirements for HFT firms." ${ }^{\text {496 }}$

The regulation of HFT in the US. In the US, the SEC has been slower in addressing HFT regulation. In March 2018, the SEC voted to adopt a "Transaction Fee Pilot" ${ }^{\mathbf{4 9 7}}$ that will allow it to analyze the effects of stock exchange transaction fee and rebate pricing models on broker buy and sell order routing and trade execution quality. Big US exchanges such as the NYSE have objected to the pilot because they fear that it would undermine their "maker-taker" system of fees and rebates. According to this system, exchanges pay rebates for some orders and charge fees for others. ${ }^{498}$

490 Recital 65 of Directive 2014/65/EU (MiFID II).

491 Recital 66 of Directive 2014/65/EU (MiFID II).

492 Recital 67 of Directive 2014/65/EU (MiFID II).

493 Recital 113 of Directive 2014/65/EU (MiFID II).

494 Recital 68 of Directive 2014/65/EU (MiFID II).

495 Article 2(1) of Directive 2014/65/EU (MiFID II): “This Directive shall not apply to: ... (d) persons dealing on own account in financial instruments ... unless such persons: ... (iii) apply a high-frequency algorithmic trading technique; ..." For the definition of "algorithmic trading" and "high-frequency algorithmic trading technique", see points (39) and (40), respectively, of Article 4(1) of Directive 2014/65/EU (MiFID II).

496 Kaya O (2016) p 4.

497 Rule 610T of Regulation NMS.

498 SEC Release No. 34-82873 (Transaction Fee Pilot for NMS Stocks), sections II.A and V.A.1. 
The SEC has already taken some steps in this area. The SEC has: revamped single-stock circuit breakers (the function of which is to pause trading in a given NMS stock across US equity markets for a five-minute period in the event that the stock experiences a significant price decline over the preceding five minutes); instituted the Limit-Up Limit-Down Rule; passed Regulation Systems Compliance and Integrity; and imposed stringent compliance and monitoring requirements on most trading platforms. ${ }^{499}$

The SEC aims to do more. It aims to: introduce an anti-disruptive trading rule; improve risk management practices for trading algorithms; and enforce stricter use of its core tool of registration and oversight. ${ }^{500}$

\subsubsection{Conclusions}

The market share of alternative trading mechanisms grew after the turn of the millennium for several reasons. Alternative trading mechanisms were generally made possible by digitalisation. Digitalisation also changed the revenue models of the operators of trading venues. Competition for listings was largely replaced by competition for trading volume with new trading venues trying to increase their share of trading in the most traded stocks. For this purpose, stock exchanges courted high-volume customers such as high-frequency traders. High-frequency traders benefited from one-sided liquidity and practiced front running. To avoid front running, other large customers turned to dark pools. Dark pools obtained a large market share. Large broker-dealers could use trade internalisation. New trading venues could even specialise in different customer segments.

The growth of alternative trading mechanisms and trade fragmentation was facilitated by regulation. Regulation NMS is regarded as the watershed event in the US. In the EU, the focus was on creating a level playing field for trading venues and on facilitating cross-border business. The problem of HFT was addressed

499 Morelli M (2017) p 216. For circuit breakers, see SEC Release No. 34-62252 (June 10, 2010) (Order Granting Accelerated Approval to Proposed Rule Changes Relating to Trading Pauses Due to Extraordinary Market Volatility); SEC Release No. 34-67091 (May 31, 2012) (Order Approving the NMS Plan to Address Extraordinary Market Volatility). For limit-up limit-down price bands, see FINRA Rules, at Rule 6190; NMS Plan to Address Extraordinary Market Volatility as amended by SEC Approval Order, SEC Release No. 34-77679 (April 21, 2016). For monitoring, see SEC Release No. 34-73639 (November 19, 2014) (Regulation Systems Compliance and Integrity), 79 FR 72252 (December 5, 2014) (SCI Adopting Release).

500 Kaya O (2016) p 4; Morelli M (2017) pp 217 and 220. 
in the EU by waivers from pre-trade and post-trade transparency, rules on algorithmic trading, and rules on artificially slowing down trade order speeds.

Alternative trading mechanisms emerged because of competition for trading volume between various players in the financial industry. Existing regulation mainly seems to serve the interests of the operators of trading venues and high-volume traders, or address problems created by regulation.

Alternative trading mechanisms did not emerge because of the needs of issuer-firms. The needs of issuer-firms have not mattered so far. The existing regulation of alternative trading mechanisms therefore hampers the development of alternative trading mechanisms designed to benefit issuer-firms. A new regulatory regime would be necessary in particular to create new secondary markets for illiquid stocks such as shares in SMEs and growth firms. SME exchanges emerged as an alternative designed to address the needs of such issuer-firms (section 3.5).

\subsection{SME Exchanges}

\subsubsection{General Remarks}

The emergence of particular SME exchanges, that is, exchanges or market segments intended to attract young growth companies especially in the technology sector, had little connection to the emergence of alternative trading venues (sections 3.3 and 3.4). Its drivers were the dotcom boom, concerns about growth and employment after the financial crisis of 2007-2009, the growth of emerging markets, and generally competition between stock exchange operators. SME exchanges are a sub-category of traditional exchanges rather than examples of alternative trading venues. While SME exchanges have helped many firms, they have not managed to create enough companies with publicly-traded shares.

The function of SME exchanges for SMEs. According to a World Bank study, ${ }^{501}$ SME exchanges have a function for SMEs as SMEs need capital and various kinds of services.

SME’s need equity financing: "Equity financing can help SMEs get beyond some of the constraints associated with bank financing because it is longer term, does not need to be paid back, and increases an SME's ability to raise

501 Harwood A, Konidaris T (2015). 
bank financing and take on debt."502 Equity financing can be provided first by venture capital investors and then by market investors via an SME exchange.

Investors provide different ancillary services to SMEs. While a venture capital investor can "help the entrepreneur obtain strategic advice, technology, or support" and "help the SME improve its overall operations, including governance and financial accounts", ${ }^{503}$ raising capital from market investors via an SME exchange is "appropriate when the SME is less interested in obtaining management assistance or restructuring but needs capital to grow". ${ }^{504}$

One can distinguish between the core and ancillary services that an SME exchange provides to the issuer. There are two core services in the light of the World Bank study.

First, an SME exchange can provide access to capital: "By appealing to a broader, more diverse investor base, an IPO can provide access to capital without requiring the SME to relinquish majority control. SME exchanges link issuers requiring long-term financing with a diverse set of investors comfortable with taking equity market risk by providing an infrastructure and regulatory framework that addresses the key risks for both." ${ }^{505}$

Second, an SME exchange facilitates secondary trading that can foster the interests of the firm: "It provides early-stage financiers ... with an exit vehicle, which can, in turn, encourage them to provide more early-stage financing from the comfort that having an exit provides, and allows them to recycle their investment." 506

Of these two core services, the second seems to be more important as has been pointed out by Bengt Holmström: "Start-ups, family businesses and other companies that list themselves for the first time on a stock exchange do raise substantial amounts of money at times, but little of it goes into the firm. The purpose is usually to allow entrepreneurs and family members to reduce their risk exposure, or resolve conflicts of interest that are common among closely held firms with large shareholders."507 SEC Chairman Jay Clayton said that "public equity markets-e.g., IPOs-are being used more for liquidity by venture capital and private equity investors than for accessing new growth capital". ${ }^{508}$

The core services are complemented by various kinds of ancillary services ranging from a signalling effect to education. An SME exchange listing has a sig-

502 Ibid., p 13.

503 Ibid.. See also OECD (2015c) p 110; Ibrahim DM (2013) pp 254-255.

504 Harwood A, Konidaris T (2015) p 13.

505 Ibid., p 13.

506 Ibid., p 13.

507 Holmström B (2015) p 7.

508 Clayton J (2019). 
nalling effect as it can improve the perceived characteristics or reputation of the firm, reduce the perceived risk exposure of the parties that do business with the firm, and increase product sales. ${ }^{509}$ The exchange operator can even actively provide education as an ancillary service. This can be illustrated with Euronext. In September 2015, Euronext launched TechShare, a 10-month educational and mentoring programme aimed at familiarising tech company CEOs with the financial markets. In 2017, Euronext launched FamilyShare, a dedicated programme offering support and coaching to unlisted family businesses. ${ }^{510}$

Demand for marketplaces is two-sided as both issuers and investors need marketplaces. Since the number of IPOs is rather low, the potential demand for marketplaces that provide relevant core and ancillary services and the actual supply of marketplaces do not meet. ${ }^{511}$

Cases. Many SME exchanges were inspired by the success of National Association of Securities Dealers Automated Quotation or NASDAQ. ${ }^{512}$ Founded in 1971, Nasdaq introduced all-electronic trading and attracted young growth companies such as Microsoft, Apple, Cisco, Oracle, and Dell. Nasdaq was made famous by the dotcom boom.

However, it turned out to be difficult to copy the Nasdaq concept and build successful SME exchanges in other countries. ${ }^{513}$ The difficulties can be illustrated with the short history of the German Neuer Market and the French Nouveau Marché.

Neuer Markt was launched by Deutsche Börse AG in April 1997.514 It prospered during the dotcom era and peaked in 2000. When interest in the hightech and telecom sector dried up, Deutsche Börse AG closed the Neuer Markt segment in 2003 (see also section 5.4.7 on Neuer Markt and Scale).

Founded in 1996, the Nouveau Marché was intended as Nasdaq's French equivalent. Most of the companies listed on the Nouveau Marché were in the

509 Harwood A, Konidaris T (2015) p 13.

510 Euronext, 2018 Registration Document including the Annual Financial Report, p 28.

511 In contrast, the EU IPO Task Force regarded SMEs as the supply side and investors as the demand side. European IPO Task Force (2015) pp 23 and 35.

512 OECD (2015c) p 129: "Historically, new markets have represented a source of equity financing for young high-tech companies. In fact, the prototypical model of an SME exchange was NASDAQ in the United States, founded in 1971, which was heavily weighted toward new and high technology companies, although it has then evolved into the listing place of choice for many of the largest companies in the world."

513 Harwood A, Konidaris T (2015) p 5; World Federation of Exchanges (2018) p 9; OECD (2015c) p 14.

514 See Harrer H, Erwe P (1998); Vitols S (2001); Burghof HP, Hunger A (2003); Gilson RJ, Hansmann H, Pargendler M (2011) p 504. 
technology sector. Like the Neuer Markt, Nouveau Marché suffered from the bursting of the dotcom bubble in 2000. A single regulated market was created to replace Nouveau Marché and two other market segments in 2005.

Some SME markets have done well. In London, the Alternative Investment Market (AIM) has become one of the most successful SME markets. ${ }^{515}$ It has achieved a high number of listings but mostly failed to create high returns for late investors. ${ }^{516}$ Successful markets can vary greatly in terms of the number of listed companies and market capitalisation. Other SME markets that have done well include, for example, Euronext Growth (of Euronext, a pan-European exchange), KOSDAQ (of Korea Exchange) and ChiNext (of Shenzhen Stock Exchange) as well as TSX Venture Exchange (of TMX Group, Canada), JASDAQ (of Japan Exchange Group), its sister exchange Mothers (the Market of the high-growth and emerging stocks), Taipei Exchange (Taiwan), and New Connect (of Warsaw Stock Exchange). ${ }^{517}$ SME markets have found fertile ground in emerging markets. $^{518}$

SME exchanges after the financial crisis of 2007-2009. The slow recovery after the financial crisis of 2007-2009 made policymakers pay more attention to the role of SMEs as engines of growth and employment.

Since bank financing is the primary source of funding for most SMEs, policymakers and regulators found it necessary to focus on the access of SMEs to capital market financing and on the role of SME exchanges. ${ }^{519}$ For example, the JOBS Act of 2012 was intended to increase the liquidity of SME equity markets in the US, ${ }^{520}$ and MiFID II that was adopted in 2014 strengthened the protection of investors and provided for a new type of trading venue designed to cater specifically for SME issuers. ${ }^{521}$

Policymakers' recommendations influenced subsequent regulation. In the US, the October 2011 report of the IPO Task Force was followed by the Jumpstart Our Business Startups (JOBS) Act of 2012. In the EU, elements of the European

515 Harwood A, Konidaris T (2015) p 9; World Federation of Exchanges (2018) p 10, Table 1. 516 Claer Barrett, Aim - 20 years of a few winners and many losers: Why has London's junior market performed so poorly? Financial Times, 19 June 2015.

517 World Federation of Exchanges (2018) p 10, Table 1; Harwood A, Konidaris T (2015) p 11, Table 2; OECD (2015c) p 131.

518 OECD (2015c) p 132-133.

519 World Federation of Exchanges (2018) p 4. See also IPO Task Force (2011); Weild D, Kim E, Newport L (2013) (OECD); Shinozaki S (2014) (Asian Development Bank); European IPO Task Force (2015); Action Plan on Building a Capital Markets Union. Communication from the Commission, COM(2015) 468 final; OECD (2015c); Harwood A, Konidaris T (2015) (World Bank).

520 OECD (2015c) p 134.

521 Ibid. 
IPO Task Force's recommendations of 2015 were adopted in the Capital Markets Union action plan that followed MiFID II.

Emerging regulation. In this context, the main design principle applied in the US and the EU is that SME exchanges are governed by a one-size-fits-all regulatory regime that governs all stock exchanges. While this does not prevent the founding of SME exchanges as market segments, junior markets, or standalone exchanges, such SME exchanges cannot be fundamentally different from traditional main markets. SME exchanges are designed as a sub-category of the traditional stock exchange that is primarily designed for large established issuers. The main regulatory regime is complemented by exceptions and waivers. Exceptions and waivers are regarded as necessary in both the US and the EU. The regulation of SME exchanges seems to be work in progress.

\subsubsection{The Emerging Regulation of SME Exchanges in the US}

The Order Handling Rules of 1997 and Regulation ATS of 1998 reduced trading spreads and, indirectly, the number of small company IPOs in the US. ${ }^{522}$ IPO levels are low even for many other reasons. To address this problem, there are proposals for regulatory change. Some actions were taken in the JOBS Act of 2017.

The October 2011 report of the IPO Task Force contained four high-level recommendations for policymakers: (1) provide an “on-ramp” for emerging growth companies using existing principles of scaled regulation (whereby qualified companies would be given up to five years from the date of their IPOs to scale up to full regulatory compliance); (2) improve the availability and flow of information about smaller cap companies for investors before and after an IPO (by increasing the availability of company information and research); (3) lower the capital gains tax rate for investors who purchase shares in an IPO and hold these shares for a minimum of two years; and (4) educate issuers about how to succeed in the new capital markets environment. ${ }^{523}$

The subsequent JOBS Act of 2012 introduced the notion of an "emerging growth company”. The JOBS Act defines an emerging growth company as an issuer with total annual gross revenues of less than US\$1.07 billion (originally US $\$ 1.0$ billion) in its last fiscal year before the IPO. An issuer that qualifies as an emerging growth company benefits from a temporary transition period during which an issuer's regulatory requirements phase in gradually (on-ramp). It is

522 Weild D, Kim E, Newport L (2013) p 4.

523 IPO Task Force (2011) pp 2-3. 
then exempted from certain disclosure, auditing, accounting, and other requirements that would apply otherwise. ${ }^{524}$

In principle, the Securities Exchange Act of 1934 would make it possible to found new kinds of exchanges provided that the general requirements for all exchanges are met. This was the case with LTSE in 2019.525 The SEC summed up its general requirements in its findings as follows:

"[T]he Commission finds that the proposed rules of LTSE are consistent with Section 6 of the Act in that, among other things, they are designed to: (1) assure fair representation of the exchange's members in the selection of its directors and administration of its affairs and provide that, among other things, one or more directors shall be representative of investors and not be associated with the exchange, or with a broker or dealer; (2) prevent fraudulent and manipulative acts and practices, promote just and equitable principles of trade, foster cooperation and coordination with persons engaged in regulating, clearing, settling, processing information with respect to, and facilitating transactions in securities, and remove impediments to and perfect the mechanisms of a free and open market and a national market system; (3) not permit unfair discrimination between customers, issuers, or dealers; and (4) protect investors and the public interest. The Commission also finds that the rules of LTSE are consistent with Section 11 A of the Act. Finally, the Commission finds that LTSE's proposed rules do not impose any burden on competition not necessary or appropriate in furtherance of the purposes of the Act." ${ }^{26}$

\subsubsection{The Emerging Regulation of SME Exchanges in the EU}

The European IPO Task Force recommended actions in its 2015 report. ${ }^{527}$ To some extent, they resembled the 2011 recommendations of the US IPO Task Force.

524 World Federation of Exchanges (2018) p 5; Latham \& Watkins LLP (2020) p 12.

525 See, for example, SEC Release No. 34-85828 (May 10, 2019) (In the Matter of the Application of Long Term Stock Exchange, Inc. for Registration as a National Securities Exchange. Findings, Opinion, and Order of the Commission), I: "Pursuant to Sections 6(b) and 19(a) of the Act, the Commission shall by order grant an application for registration as a national securities exchange if the Commission finds, among other things, that the proposed exchange is so organized and has the capacity to carry out the purposes of the Act and can comply, and can enforce compliance by its members and persons associated with its members, with the provisions of the Act, the rules and regulations thereunder, and the rules of the exchange."

526 Ibid., II.

527 European IPO Task Force (2015) pp 52-58. See also FESE (2019). 
The European IPO Task Force's five high-level recommendations were: (1) "Create a more flexible regulatory environment for small and mid-cap quoted companies, also known as 'Emerging Growth Companies', including lowering the barriers to entry and the cost of equity capital." (2) "Relax constraints that restrict investors' ability to access IPO markets \& to invest in venture capital / private equity." (3) "Improve the ecosystem of IPOs and market structures to better serve companies at different stages of growth and different types of investors." (4) "Create an equity culture in Europe, including the provision of education and non-legislative initiatives."528 (5) "Improve tax incentives for investment into IPOs and equity more generally."

Each high-level recommendation was complemented by a list of more specific aims. One of the more specific aims that complemented the first high-level recommendation was: "Promote the concept of 'Think Small First' in EU financial regulation affecting Emerging Growth Companies”. Earlier, the principle of "Think Small First" had influenced the UK Company Law Reform of 2006 (section 2.4.9). ${ }^{529}$ The European Commission emphasised the importance of the "Think Small First" principle in its 2008 Small Business Act. ${ }^{530}$ According to the European Commission, this principle means that policy-makers should consider and take into account the needs and interests of SMEs from the earliest moment in policy formulation.

One of the specific aims complementing the second high-level recommendation was creating "a single market for retail investors to directly access public equity markets cross-border in Europe (in addition to investment with financial intermediation)". 531

The European IPO Task Force gave its recommendations in 2015 after the adoption of MiFID II in 2014. MiFID II therefore did not solve the problems and there is more work to do.

In any case, the first high-level recommendation was connected to the regulation of SME growth markets as a particular category of multilateral trade facilities (MTFs) under MiFID II. ${ }^{532}$ SME growth markets are subject to lighter regulatory requirements depending on the preferences of each Member State. ${ }^{533}$ The

528 See also FESE (2019) p 23 and OECD (2015c) p 130: "Evidence shows that the lack of an equity culture represents a greater impediment in Europe than in the US."

529 See [the UK] Department of Trade and Industry (2005); [the UK] Companies Act 2006.

530 "Think Small First" - A "Small Business Act" for Europe. Communication from the Commission, COM(2008) 394 final.

531 European IPO Task Force (2015) p 53.

532 Point 12 of Article 4(1) of Directive 2014/65/EU (MiFID II).

533 Article 33(3) of Directive 2014/65/EU (MiFID II). 
operator of the market nevertheless is not exempted from other obligations under MiFID II relevant to the operation of MTFs. ${ }^{534}$

The common regulatory standards for SME growth markets are a compromise between the various regulatory goals of MiFID II. According to the recitals of MiFID II, ${ }^{535}$ its provisions on SME growth markets are intended to:

- facilitate access to capital for smaller and medium-sized enterprises (SMEs);

- facilitate the further development of specialist markets that aim to cater for the needs of smaller and medium-sized issuers;

- create within the MTF category a new sub-category of SME growth market;

- through creation of a new sub-category of SME growth market and the registration of those markets, raise their visibility and profile;

- through creation of a new sub-category of SME growth market and the registration of those markets, aid the development of common regulatory standards in the Union for those markets;

- through future regulation, further foster and promote the use of that market so as to make it attractive for investors;

- through future regulation, provide a lessening of administrative burdens;

- through future regulation, provide further incentives for SMEs to access capital markets through SME growth markets;

- provide sufficient flexibility to be able to take into account the current range of successful market models that exist across Europe;

- strike the correct balance between maintaining high levels of investor protection, which are essential to fostering investor confidence in issuers on those markets, while reducing unnecessary administrative burdens for issuers on those markets;

- provide a basis for more detailed SME growth market requirements such as those relating to criteria for admission to trading on such a market would be further prescribed in delegated acts or technical standards.

In the European Commission's Capital Markets Union action plan, these numerous goals were reduced to just two. The Commission promised to "ensure through the implementation of MiFID II that the requirements applying to [SME growth markets] strike the right balance between providing sufficient investor protection and avoiding unnecessary administrative burden." 536

534 Article 33(4) of Directive 2014/65/EU (MiFID II).

535 Recitals 132-133 of Directive 2014/65/EU (MiFID II).

536 Action Plan on Building a Capital Markets Union. Communication from the Commission, COM(2015) 468 final, Chapter 2. 
The same two SME-related goals influenced the new Prospectus Regulation. For example, the purpose of the Prospectus Regulation is to establish "a specific proportionate EU Growth prospectus regime which is available to such companies. A proper balance should be struck between cost-efficient access to financial markets and investor protection when calibrating the content of an EU Growth prospectus." 537

Conclusion. Policymakers believe that many SMEs could choose to have publicly-traded shares. The US and the EU are pursuing different policy options for this purpose. In the US, the focus is on the SME in the light of the fact that "emerging growth companies" are exempt from some requirements under securities law. In the EU, the focus is on the venue in the light of the fact that MiFID II provides for "SME growth markets".

\subsection{Conclusions}

If there are too few companies with publicly-traded shares, the problem might have a connection to how stock exchanges work and how they are regulated. This seems to be the case.

Early stock exchanges fostered the interests of the state, firms, and traders. In contrast, the operators of modern stock exchanges are for-profit enterprises. Neither their business models nor the regulation of stock exchanges are designed with the interests of issuer-firms in mind.

The emergence of alternative marketplaces has not helped. The drivers of this phenomenon include digitalisation, regulatory changes, competition between trading venues for trading volume, and addressing front running or one-sided liquidity either as an opportunity or as a threat. ${ }^{538}$ The interests of issuer-firms remain absent in the business and regulation of alternative marketplaces. The rise of broker-dealer order internalisation and dark pools in particular is connected to the threat of front running and one-sided liquidity, competition for large orders, and the general trend of concentration of intermediaries.

This said, the role of SMEs and growth firms was recognised in the development of SME exchanges. SME exchanges grew because of the dotcom boom and start-up hype, concerns about economic growth and employment after the financial crisis of 2007-2009, the growth of emerging markets, and generally competition between exchanges. However, SME exchanges are traditional rather than

537 Recital 51 of Regulation 2017/1129 (Prospectus Regulation). 538 See even Fox MB, Glosten LR, Rauterberg GV (2019) p 14. 
alternative marketplaces. The default regulatory framework of an SME exchange is that of a traditional stock exchange. The regulation of SME exchanges basically means adopting exceptions to the main regulatory framework that governs traditional stock exchanges. The fundamental problems of SME exchanges and their regulation may reflect the fact that the mechanisms of traditional stock exchanges are designed for mature companies with liquid shares. The shares of SMEs are inherently illiquid.

In the light of the long-term decline in the number of new listings, supply and demand do not seem to meet as far as the product "trading venue for stocks" is concerned. On the issuer side, there is a shortage of trading venues as existing trading venues are not aligned with the interests of firms. Retail investors suffer from a shortage of issuers.

The regulation of stock exchanges should even foster the interests of non-financial issuer-firms. It should not be limited to fostering the interests of trading venue operators, institutional investors, high-volume traders, and high-frequency traders.

SME exchanges can help to bring more companies to public markets. However, the use of traditional SME exchanges does not seem to be enough to cure the fundamental problem. There should be alternative trading venues for issuers that are SMEs. In this book, the development of "microexchanges" as a new kind of trading venue is proposed as one of the possible ways to address the lack of proper trading venues for SMEs' stocks (Chapter 8).

One may ask whether the development of marketplaces that foster the interests of issuer-firms rather than traders and marketplaces designed for SMEs would lead to market fragmentation and reduce liquidity. This question may not be the right question to ask. There is already a trend of market fragmentation and a new approach to liquidity regardless of the interests of issuer-firms.

Since different investors and traders have different needs, there is now "horizontal differentiation between venues in terms of the services offered and the clients targeted". 539 The existence of different kinds of marketplaces ranging from main exchanges to dark pools indicates that market fragmentation is now part of the normal evolution of stock exchanges. The phenomenon of concentration has moved from trading venues to intermediaries with some market players becoming TBTF.

At the same time, regulatory actions intended to ensure liquidity have increasingly contributed to fragmentation rather than concentration. In the US, one of the main drivers of fragmentation was Regulation NMS that created the

539 Petrescu M, Wedow M (2017) p 7. 
national stock market with increased liquidity. However, if one assumes that liquidity means the same thing to all market participants and is the core service of stock exchanges that can reduce fixed costs per transaction by increasing trading volume, two-sided network effects should lead to the concentration of stock exchanges. The fragmentation of stock markets with many new trading venues indicates that something else is going on. It could indicate that liquidity does not mean the same thing to all market participants, that two-sided liquidity is not the most important thing for all operators of trading venues, or that the fixed costs of trading venues do not matter as much as they used to and the provision of liquidity is a commodity. Lower fixed costs can increase the number of trading venues. In any case, there is reason to look at new ways to address liquidity in the future (sections 5.5.4 and 6.3.15).

If the trend of market fragmentation continues without an increase in the number of companies with publicly-traded shares, more trading venues will end up chasing the same limited pool of issuers. Where will this lead? The most extreme outcome of such a long-term trend would be a personal trading platform for each investor. On the issuer side, the most extreme outcome would be a trading venue for each issuer. Perhaps the two extreme outcomes can be combined in a way that is not as absurd as it seems. In fact, this is what we will propose in this book (Chapter 8).

The business models of firms that participate in the operation of trading platforms have changed. These firms currently provide various kinds of services. In the future, the firms that provide the plumbing of stock markets can be expected to focus on achieving positive network effects in novel ways.

\section{References}

Adrian J (2015-2016) Informational Inequality: How High Frequency Traders Use Premier Access to Information to Prey on Institutional Investors. Duke Law \& Technology Review 14(1):256-279

Aggarwal R, Ferrell A, Katz J (2007) U.S. Securities Regulation in a World of Global Exchanges. ECGI Finance Working Paper No. 146/2007

Aguilar LA (2015) Shedding light on dark pools. U.S. Securities and Exchange Commission, Public Statement, Commissioner Luis A. Aguilar, Nov. 18, 2015

Allen H, Hawkins J, Sato S (2001) Electronic trading and its implications for financial systems. In: Bank for International Settlements, Electronic finance: a new perspective and challenges, BIS Papers No 7, pp 30-52

Bagheri M, Nakajima C (2004) Competition and Integration among Stock Exchanges: The Dilemma of Conflicting Regulatory Objectives and Strategies. Oxford Journal of Legal Studies 24(1):69-97 
Baron M, Brogaard J, Kirilenko A (2012) The Trading Profits of High Frequency Traders. Working Paper, August 2012

Baskin JB, Miranti PJ Jr (1997) A History of Corporate Finance. Cambridge University Press, Cambridge and New York

Baum H (2002) Technological Innovation as a Challenge to Exchange Regulation: First Electronic Trading, Then Alternative Trading Systems and Now "Virtual" (Internet) Exchanges? In: Kono T, Paulus C, Rajak H (Eds.) Selected Legal Issues of E-Commerce. Kluwer Law International, Den Haag, London, New York pp 99-125

Baum H (2004) Changes in Ownership, Governance and Regulation of Stock Exchanges in Germany: Path Dependent Progress and an Unfinished Agenda. European Business Organization Law Review 5(4):677-704

Ben Slimane F (2012) The Structural Evolution of Stock Exchanges. Recherches en Sciences de Gestion 6(93):47-71

Blume ME (2000) The Structure of the US Equity Markets. Paper Prepared for Financial Markets Conference, Federal Reserve Bank of Atlanta, Sea Island, Georgia, October 16, 2000

Burghof HP, Hunger A (2003) Access to Stock Markets for Small and Medium-Sized Growth Firms: The Temporary Success and Ultimate Failure of Germany's Neuer Markt. Working paper, October 2003

Clark-Joseph AD (2013) Three Essays on Trading Behavior. Doctoral dissertation, Harvard University

Christiansen H, Koldertsova A (2009) The role of stock exchanges in corporate governance. OECD Journal: Financial Market Trends, vol. 2009/1 pp 209-238. OECD, Paris

Chwieroth JM (2010) Capital ideas: The IMF and the Rise of Financial Liberalization. Princeton University Press, Princeton

Clayton J (2019) SEC Chairman Jay Clayton, Remarks to the Economic Club of New York, 9 September 2019

Damrau J (2003) Selbstregulierung im Kapitalmarktrecht: Eine rechtsökonomische Analyse der Normsetzung der deutschen Börsen und ihrer Träger. Diss. Göttingen 2003. Tenea, Berlin

Demarchi M, Foucault T (2000) Equity Trading Systems in Europe: A Survey of Recent Changes. Annales d'Économie et de Statistique 60:73-115

Deutsche Börse AG (2017) Scale: a comprehensive ecosystem for growth. Interview with Renata Bandov on Deutsche Börse's new SME segment, 5 May 2017

Deutsche Börse AG (ed) (2001) Neuer-Markt-Report. Zugang zu Europäischen Kapitalmarkt Schlüssel für Wachstum. Frankfurt am Main

Díez FJ, Leigh D, Tambunlertchai S (2018) Global Market Power and its Macroeconomic Implications. IMF Working Paper WP/18/137. Western Hemisphere Department and Research Department. International Monetary Fund, June 2018

Domowitz I, Steil B (2002) 12 Securities Trading. In: Steil B, Victor DG, Nelson RR (eds) Technological Innovation and Economic Performance. A Council on Foreign Relations Book. Princeton University Press, Princeton and Oxford, pp 314-326

Engelen E, Grote MH (2009) Stock exchange virtualisation and the decline of second tier financial centres: the cases of Amsterdam and Frankfurt. Journal of Economic Geography 9(5):679-696 
ESMA (2015) Final Report: Draft Regulatory and Implementing Technical Standards MiFID II/ MiFIR. ESMA/2015/1464, 28 September 2015

European Central Bank (2007) The Stock Market's Changing Structure and its Consolidation: Implications for the Efficiency of the Financial System and Monetary Policy. ECB Monthly Bulletin, November, pp 61-74

European Commission (2010) Public consultation: Review of the Markets in Financial Instrument Directive (MiFID). Directorate General Internal Market and Services. Financial Services Policy and Financial Markets. Securities Markets. 8 December 2010

European IPO Task Force (2015) EU IPO Report: Rebuilding IPOs in Europe - Creating jobs and growth in European capital markets. Issued by the European IPO Task Force, 23 March 2015

Ferrell A (2007) Written Testimony Submitted by Professor Allen Ferrell - Greenfield Professor of Securities Law Harvard Law School - Before the Senate Subcommittee on Securities, Insurance and Investment: "A Global View: Examining Cross-Border Exchange Mergers". July 12,2007

FESCO (2000) The Regulation of Alternative Trading Systems in Europe. A paper for the EU Commission. Fesco/00-064c, September 2000

Fioravanti SF, Gentile M (2011) The impact of market fragmentation on European stock markets. CONSOB Working Paper, No 69, July 2011

Fleckner AM (2006) Stock Exchanges at the Crossroads. Fordham Law Review 74(5):2541-2620

Floreani J, Polato M (2010) Consolidation and Business Strategies in the Securities Industry: How Securities Exchanges Create Value? Research in World Economy 1(1):28-42

Floreani J, Polato M (2013) Changing Paradigms in Stock Exchanges' Governance. Journal of Applied Finance \& Banking 3(5):169-185

Foley S, Putninš T (2016) Should We Be Afraid of the Dark? Dark Trading and Market Quality. Journal of Financial Economics 122(3):456-481

Fox MB, Glosten LR, Greene EF, Patel MS (2018) Chapter 1. Securities Market Issues for the 21st Century: An Overview. In: Fox MB, Glosten LR, Greene EF, Patel MS (eds) Securities Market Issues for the 21st Century. Prepared in connection with The New Special Study a project of Columbia Law School \& Columbia Business School's Program in the Law and Economics of Capital Markets. Independently published, pp 1-33

Fox MB, Glosten LR, Rauterberg GV (2019) The New Stock Market: Law, Economics, and Policy. Columbia University Press, New York

Gadinis S (2008) Market Structure for Institutional Investors: Comparing the U.S. and E.U. Regimes. Virginia Law \& Business Review 3(2):311-356

Hardy CO (1939/1975) Odd-lot Trading on the New York Stock Exchange. The Brookings Institution, Washington, D.C. (Reprint Edition 1975, reprint of the edition published as Publication No. 78 of the Institute of Economics of the Brookings Institution. Arno Press, New York)

Harrer H, Erwe P (1998) Der Neue Markt der Frankfurter Wertpapierbörse im Vergleich zu NASDAQ und EASDAQ. Recht der internationalen Wirtschaft 44(9):661-674

Hart O, Moore J (1996) The Governance of Exchanges: Members' Cooperatives versus Outside Ownership, Oxford Review of Economic Policy 12(4):53-69 
Harwood A, Konidaris T (2015) SME Exchanges in Emerging Market Economies: A Stocktaking of Development Practices. Policy Research Working Paper 7160. Finance and Markets Global Practice Group, World Bank Group, Washington, DC

Heminway JM (2017) Selling Crowdfunded Equity: A New Frontier. Oklahoma Law Review 70(1):189-213

Hintz A (2015) Lost in the Dark: An Analysis of the SEC's Regulatory Response to Dark Pools. DePaul Business and Commercial Law Journal 13(2):329-357

Hirschman AO (1970) Exit, Voice, and Loyalty: Responses to Decline in Firms, Organizations, and States. Harvard University Press, Cambridge, Mass.

Holmström B (2015) Understanding the Role of Debt in the Financial System. BIS Working Paper No 479, January 2015

Ibrahim DM (2019) Public or Private Venture Capital? Washington Law Review 94:1137-1174

IOSCO (2001) Issues Paper on Exchange Demutualization. Report of the Technical Committee of the International Organization of Securities Commissions, June 2001

IOSCO (2005) Exchange Demutualization in Emerging Markets. Emerging Markets Committee of the International Organisation of Securities Commissions, April 2005

IPO Task Force (2011) Rebuilding the IPO On-Ramp. Putting Emerging Companies and the Job Market Back on the Road to Growth. Issued by the IPO Task Force. October 20, 2011

Kaya $O$ (2016) High-frequency trading: Reaching the limits. Deutsche Bank Research. Research Briefing Global financial markets. May 24, 2016

Kirilenko AA, Kyle AS, Samadi M, Tuzun T (2017) The Flash Crash: High-Frequency Trading in an Electronic Market. Journal of Finance 72(3):967-998

Kröner A, Jones K (2016) Börse startet Wachstums-Segment: Jetzt kommt der neue Neue Markt, manager-magazin, 22 November 2016

Köndgen J (1998) Ownership and Corporate Governance of Stock Exchanges. Journal of Institutional and Theoretical Economics (JITE) / Zeitschrift für die gesamte Staatswissenschaft 154(1):224-251

Lagneau-Ymonet P, Riva A (2019) Trading Forward: The Paris Bourse in the Nineteenth Century. INCAS Discussion Paper Series 2019 \#01, halshs-01984911

Latham \& Watkins LLP (2020) US IPO Guide. 2020 Edition, July 31, 2020

Lee $R$ (1998) What is an Exchange? The Automation, Management and Regulation of Financial Markets. Oxford University Press, Oxford

Lerch MP (2017) § 25 Algorithmic Trading and High-Frequency Trading. In: Veil R (ed) European Capital Markets Law. Second Edition. Hart Publishing, Oxford and Portland, pp 476-520

Macey JR, Kanda H (1990) Stock Exchange as a Firm: The Emergence of Close Substitutes for the New York and Tokyo Stock Exchanges. Cornell Law Review 75(5):1006-1052

Macey JR, O’Hara M (2005) From Markets to Venues. Securities Regulation in an Evolving World. Stanford Law Review 58:563-599

MacIntosh JG (2013) High Frequency Traders: Angels or Devils? C.D. Howe Institute, commentary no. 391

Mahoney PG, Rauterberg GV (2018) Chapter 5. The Regulation of Trading Markets. In: Fox MB, Glosten LR, Greene EF, Patel MS (eds) Securities Market Issues for the 21st Century. Prepared in connection with The New Special Study a project of Columbia Law School \& Columbia Business School's Program in the Law and Economics of Capital Markets. Independently published, pp 222-278 
Manne HG (1965) Mergers and the Market for Corporate Control. The Journal of Political Economy 73(2):110-120

Mayer C (1990) Financial Systems, Corporate Finance, and Economic Development. In:

Hubbard G (ed) Asymmetric Information, Corporate Finance, and Investment. University of Chicago Press, Chicago, pp 307-332

Mayer C (1998) New issues in corporate finance. European Economic Review 32(5):1167-1183

Mishkin FS, Eakins SG (2012) Financial markets and institutions. Seventh Edition. Pearson, Harlow

Moloney N (2014) EU Securities and Financial Markets Regulation. Third Edition. Oxford University Press, Oxford

Morelli M (2017) Implementing High Frequency Trading Regulation: A Critical Analysis of Current Reforms. Michigan Business and Entrepreneurial Law Review 6(2):201-229

Morley J (2014) The Separation of Funds and Managers: A Theory of Investment Fund Structure and Regulation. The Yale Law Journal 123(5):1118-1287

Mues J (1999) Die Börse als Unternehmen: Modell einer privatrechtlichen Börsenorganisation. Studien zum Bank- und Börsenrecht 48. Dissertation, the University of Bonn. Nomos, Baden-Baden

OECD (2011) International capital flows: Structural reforms and experience with the OECD Code of Liberalisation of Capital Movements. Report from the OECD to the G20 SubGroup on Capital Flow Management. June 2011

OECD (2015c) New Approaches to SME and Entrepreneurship Financing: Broadening the Range of Instruments. OECD Publishing, Paris

Ostrom E (1990) Governing the Commons. Cambridge University Press, Cambridge Ostrom E (2005) Understanding Institutional Diversity. Princeton University Press, Princeton Ostrom E (2010) Beyond Markets and States: Polycentric Governance of Complex Economic Systems. Prize Lecture, December 8, 2009. In: Grandin K (ed) La Prix Nobel. Nobel Foundation, Stockholm, pp 408-444 and American Economic Review 100(3):641-672

Parker W (1920) The Paris Bourse and French Finance: With Reference to Organized Speculation in New York. Dissertation, Faculty of Political Science, Columbia University, New York

Petrescu M, Wedow M (2017) Dark pools in European equity markets: emergence, competition and implications. European Central Bank, Occasional Paper Series No 193, July 2017

Plückelmann K (2000) Der Neue Markt der Deutsche Börse AG. Peter Lang Gmbh, Frankfurt am Main

SEC (2000) Special Study: Electronic Communication Networks and After-Hours Trading. Division of Market Regulation, June 2000

Shearman \& Sterling (2001) Genügt das deutsche Kapitalmarktrecht internationalen Standards? In: Deutsche Börse AG (ed) Neuer-Markt-Report. Zugang zu Europäischen Kapitalmarkt - Schlüssel für Wachstum. Frankfurt am Main, pp 54-93

Shinozaki S (2014) Capital Market Financing for SMEs: A Growing Need in Emerging Asia. ADB Working Paper Series on Regional Economic Integration, No 121. Asian Development Bank, January 2014

Shorter G, Miller RS (2014) Dark Pools in Equity Trading: Policy Concerns and Recent Developments. Congressional Research Service. September 26, 2014 
Special Study of Securities Markets (1963a) Report of Special Study of Securities Markets of the Securities and Exchange Commission. 88th Congress, 1st Session. House Document No. 95, Pt. 1. U.S. Government Printing Office, Washington

Steil B (2001) Borderless trading and developing securities markets. In: R Litan, P Masson, M Pomerleano (eds) Open Doors: Foreign Participation in Financial Systems in Developing Countries. Brookings Institution Press, Washington D.C., pp 327-350

Steil B (2002a) Changes in the Ownership and Governance of Securities Exchanges: Causes and Consequences. Brookings-Wharton papers on financial services 5:61-82. DOI $10.1353 / \mathrm{pfs} .2002 .0021$

Sylla R (2005) The Origins of the New York Stock Exchange. In: Goetzmann WN, Rouwenhorst KG (eds) The Origins of Value: The Financial Innovations That Created Modern Capital Markets. Oxford University Press, Oxford, pp 299-312

Teweles RJ, Bradley ES (1998) The Stock Market. Seventh Edition. John Wiley \& Sons, Inc., New York

Van Alstyne MW, Parker GG, Choudary SP (2016) Platform Revolution: How Networked Markets Are Transforming the Economy - And How to Make Them Work for You. W.W. Norton \& Company, New York

Vidal E (1910) The History and Methods of the Paris Bourse. Government Printing Office, Washington

Walker DA (2001) A factual account of the functioning of the nineteenth-century Paris Bourse. European Journal of the History of Economic Thought 8(2): 186-207

Warren MG (1994) The European Union's Investment Services Directive. University of Pennsylvania Journal of International Law 15(2):181-220

Weber M (1894) Die Börse. I. Zweck und äußere Organisation. Vandenhoeck und Ruprecht, Göttingen. Published even in: Gesammelte Aufsätze zur Soziologie und Sozialpolitik. Verlag von J. C. B. Mohr (Paul Siebeck), Tübingen, pp 256-288

Wiener FA (1905) Börse: Eine Studie über die Entwicklung des Rechts und der Verfassung der deutschen, insbesondere der Berliner Börse und der hauptsächlichsten Börsen des Auslandes. Mit einem Anhang über den Begriff "Börse" und ihre volkswirtschaftliche Bedeutung. Puttkammer \& Mühlbrecht, Berlin

World Federation of Exchanges (2018) WFE Report on SME Exchanges

Zhu H (2014) Do Dark Pools Harm Price Discovery? The Review of Financial Studies 27(3):747-789 